\title{
Infiltration metasomatism of the Allende coarse-grained calcium-aluminum-rich inclusions
}

\author{
Alexander N. Krot ${ }^{1 *}$ (D) Michail I. Petaev² and Kazuhide Nagashima ${ }^{1}$
}

\begin{abstract}
We report on the mineralogy, petrography, and $\mathrm{O}$ and $\mathrm{Al}-\mathrm{Mg}$ isotopic systematics of secondary mineralization in the metasomatically altered igneous Ca,Al-rich inclusions (CAls) [compact type A (CTA), B1, B2, forsterite-bearing B (FoB), and C] from the CV3 carbonaceous chondrite Allende. This alteration affected mainly melilite, and to a lesser degree anorthite, and resulted in the formation of a variety of secondary minerals, including adrianite, Al-diopside, andradite, anorthite, calcite, celsian, clintonite, corundum, dmisteinbergite, ferroan olivine, ferroan monticellite, ferroan Al-diopside, forsterite, grossular, heazlewoodite, hedenbergite, hutcheonite, kushiroite, margarite, monticellite, Na-melilite, nepheline, pentlandite, pyrrhotite, sodalite, spinel, tilleyite, wadalite, and wollastonite. The secondary mineral assemblages are mainly defined by chemical compositions of the primary melilite replaced and elements introduced by an aqueous fluid. Gehlenitic melilite ( $\left.A k_{<35}\right)$ in CTAs and mantles of B1s is mainly replaced by anorthite + grossular; clintonite, corundum, spinel, and Al-diopside are minor. Åkermanitic melilite (Åk s5-90 $_{\text {) }}$ in type B2s, FoBs, and cores of B1s is replaced by the grossular + monticellite + wollastonite, grossular + monticellite, and grossular + Al-diopside assemblages; forsterite, spinel, clintonite, and Na-melilite are minor. In type Cs, lacy melilite (åkermanitic melilite with rounded inclusions of anorthite) is pseudomorphically replaced by the grossular + forsterite + monticellite and grossular + Al-diopside assemblages; Na-melilite is minor. Primary and secondary anorthites in the peripheral portions of CAls are replaced by nepheline, sodalite, and ferromagnesian olivine. Some CAls contain voids and cracks filled by andradite, hedenbergite, wollastonite, \pm sodalite, \pm grossular, \pm monticellite, \pm tilleyite, and \pm calcite. All CAls studied are surrounded by Wark-Lovering rims, fine-grained matrix-like rims composed of lath-shaped ferroan olivine and abundant nepheline grains, and a layer of salite-hedenbergite pyroxenes + andradite + wollastonite. Grossular associating with monticellite, Al-diopside, and forsterite and replacing åkermanitic melilite $\left({ }^{27} \mathrm{Al} /{ }^{24} \mathrm{Mg} \sim 2\right)$ has high ${ }^{27} \mathrm{Al} /{ }^{24} \mathrm{Mg}$ ratios $(30-100)$ and shows no resolvable excess of radiogenic ${ }^{26} \mathrm{Mg}\left({ }^{26} \mathrm{Mg}^{*}\right)$. The ${ }^{27} \mathrm{Al} /{ }^{24} \mathrm{Mg}$ ratios $(7-10)$ and ${ }^{26} \mathrm{Mg}^{*}(2-3 \%)$ in the nearly monomineralic grossular veins crosscutting gehlenitic melilite are similar to those of the host melilite and plot along a regression line with ${ }^{26} \mathrm{Al} /{ }^{27} \mathrm{Al}$ ratio of $\sim 5 \times 10^{-5}$. Oxygen isotopic compositions of secondary minerals in the most Type Bs measured in situ with the UH Cameca ims-1280 and matrix-matched standards plot along mass-dependent fractionation line with $\Delta^{17} \mathrm{O}$ of $\sim-3 \pm 2 \%$ with $\delta^{18} \mathrm{O}$ ranging from $\sim 0$ to $\sim 10 \%$. Primary melilite and anorthite in the host CAls are similarly ${ }^{16} \mathrm{O}$-depleted, whereas spinel, forsterite, and most Al,Ti-diopside grains have ${ }^{16} \mathrm{O}$-rich compositions $\left(\Delta^{17} \mathrm{O} \sim\right.$
\end{abstract}

\footnotetext{
* Correspondence: sasha@higp.hawaii.edu

Dedicated to Ahmed El Goresy March 22, 2021, revised May 4, 2021

Submitted to a special issue of Progress in Earth and Planetary Science

'Hawai'i Institute of Geophysics and Planetology, School of Ocean and Earth

Science and Technology, University of Hawai'i at Mānoa, Honolulu, HI 96822,

USA

Full list of author information is available at the end of the article
}

\section{Springer Open}

(c) The Author(s). 2021 Open Access This article is licensed under a Creative Commons Attribution 4.0 International License, which permits use, sharing, adaptation, distribution and reproduction in any medium or format, as long as you give appropriate credit to the original author(s) and the source, provide a link to the Creative Commons licence, and indicate if changes were made. The images or other third party material in this article are included in the article's Creative Commons licence, unless indicated otherwise in a credit line to the material. If material is not included in the article's Creative Commons licence and your intended use is not permitted by statutory regulation or exceeds the permitted use, you will need to obtain permission directly from the copyright holder. To view a copy of this licence, visit http://creativecommons.org/licenses/by/4.0/. 
$-25 \pm 2 \%$ ). Secondary grossular and forsterite in type Cs and type B1 CAI TS-34 show a range of $\Delta^{17} \mathrm{O}$, from $\sim-15$ to $\sim-1 \%$; the ${ }^{16} \mathrm{O}$-enriched compositions of grossular and forsterite plot along the carbonaceous chondrite anhydrous mineral line. The similar ranges of $\Delta^{17} \mathrm{O}$ and positions on the three-isotope oxygen diagram are observed for primary anorthite; melilite is generally ${ }^{16} \mathrm{O}$-depleted compared to anorthite $\left(\Delta^{17} \mathrm{O} \sim-5\right.$ to $-1 \pm 2 \%$ ); spinel and fassaite are ${ }^{16} \mathrm{O}$-rich (except very Ti-rich fassaite in TS-34 and CTA CAIs). We conclude that Allende CAls experienced an open-system in situ metasomatic alteration at relatively high temperatures $\left(200-250{ }^{\circ} \mathrm{C}\right)$ in the presence of $\mathrm{CO}_{2}$ - and $\mathrm{H}_{2} \mathrm{O}$-bearing fluid with $\Delta^{17} \mathrm{O}$ of $\sim-3 \pm 2 \%$ followed by thermal metamorphism at $\sim 500{ }^{\circ} \mathrm{C}$ on the CV chondrite parent asteroid. During the alteration, most elements were mobile: $\mathrm{Si}, \mathrm{Na}, \mathrm{Cl}, \mathrm{K}, \mathrm{Fe}$, $\mathrm{S}$, and $\mathrm{Ni}$ were introduced; $\mathrm{Al}, \mathrm{Ti}, \mathrm{Mg}$, and Ba were locally mobilized; $\mathrm{Ca}$ and some $\mathrm{Mg}$ and $\mathrm{Al}$ were lost from the host inclusions. The alteration occurred after nearly complete decay of ${ }^{26} \mathrm{Al},>3 \mathrm{Ma}$ after crystallization of CAls with the canonical $\left({ }^{26} \mathrm{Al} /{ }^{27} \mathrm{Al}\right)_{0}$ of $(5.25 \pm 0.02) \times 10^{-5} ;{ }^{26} \mathrm{Mg}^{*}$ in grossular was inherited from the primary melilite and provide no chronological significance. Oxygen isotopic heterogeneity of primary minerals in the Allende CAls at least partly is due to isotopic exchange with an aqueous fluid that largely affected melilite, anorthite, perovskite, Zr- and Sc-rich oxides and silicates, and possibly very Ti-rich fassaite.

\section{Graphical Abstract}
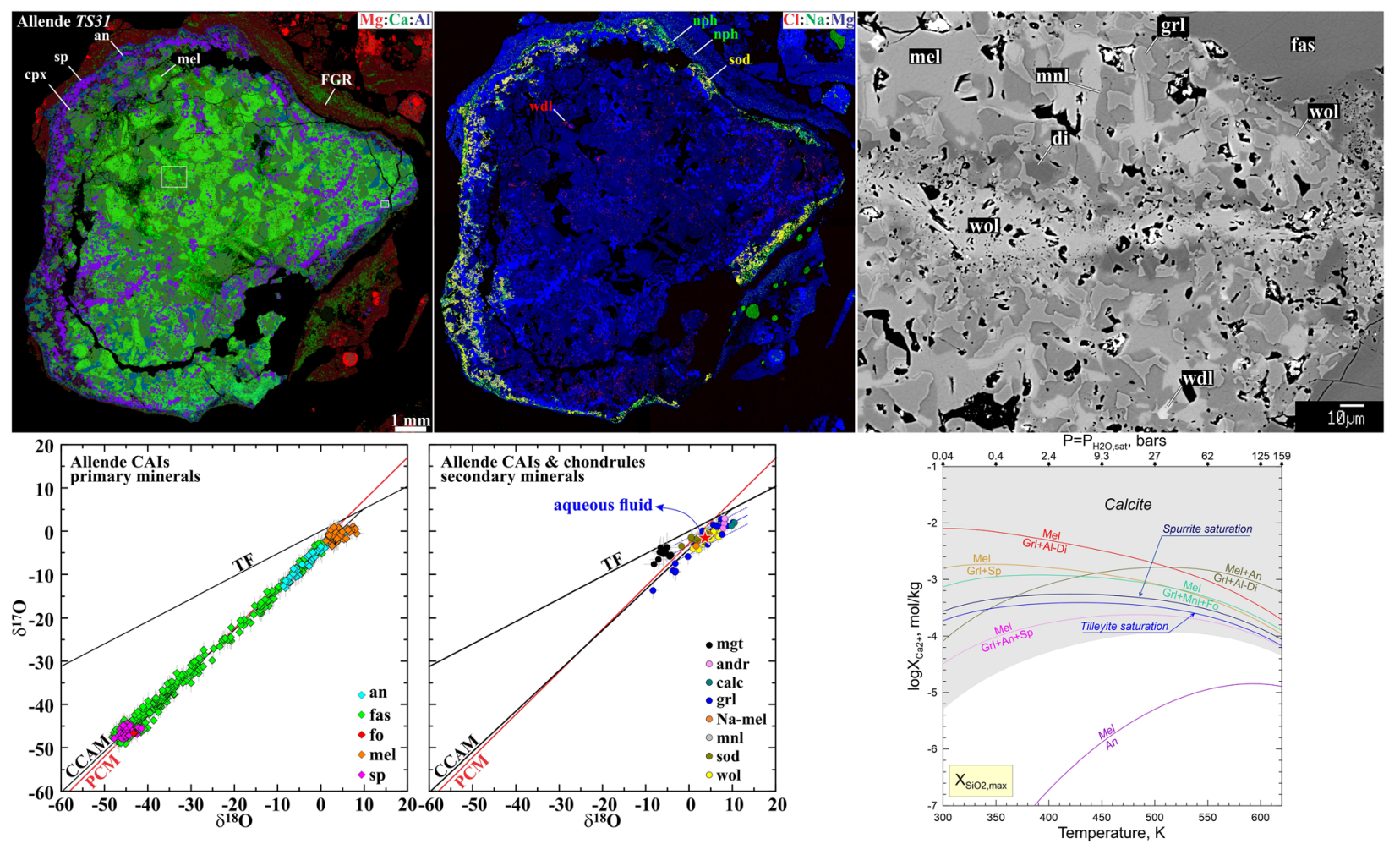

\section{Introduction}

CV (Vigarano type) carbonaceous chondrites experienced metasomatic alteration (fluid-assisted thermal metamorphism) that affected their all major components-refractory inclusions [Ca,Al-rich inclusions (CAIs) and amoeboid olivine aggregates (AOAs)], chondrules, matrix, and chondritic lithic clasts (dark inclusions) (e.g., Kimura and Ikeda 1995; Kojima and Tomeoka 1996; Krot et al. 1995, 1998a, 1998b; Brearley and Krot 2013 and references therein). It is generally accepted that the alteration of the CV chondrules, matrices, and dark inclusions occurred in an asteroidal setting in the presence of aqueous solutions $>3 \mathrm{Ma}$ after crystallization of CAIs having the canonical initial ${ }^{26} \mathrm{Al} /{ }^{27} \mathrm{Al}$ ratio $\left[\left({ }^{26} \mathrm{Al} /{ }^{27} \mathrm{Al}\right)_{0}\right]$ of $(5.25 \pm 0.02) \times 10^{-5}$ (e.g., Larsen et al. 2011; Brearley and Krot 2013 and references therein; Doyle et al. 2015; MacPherson et al. 2017). However, there is no agreement on the timing (early vs. late) and location (nebula vs. asteroid) of alteration of the CV refractory inclusions (e.g., Wark 1981; Hashimoto and Grossman 1987; McGuire and Hashimoto 1989; Fagan et al. 2005, 2006, 2007, 2015; Ushikubo et al. 2007; Krot 
et al. 2007a, 2007b, 2008; Ford and Brearley 2008), the oldest solids formed in the solar nebula (Bouvier and Wadhwa 2010; Connelly et al. 2012).

Refractory inclusions are thought to have formed near the protoSun in a highly reduced gas of approximately solar composition $\left(\mathrm{H}_{2} \mathrm{O} / \mathrm{H}_{2} \sim 6.6 \times 10^{-4}\right.$; Lodders 2021, which is consistent with an oxidation state of titanium $\left(\mathrm{Ti}^{3+} / \mathrm{Ti}^{4+}\right.$ ratio) in CAI fassaites (Simon et al. 2007) and the observations that vast majority of CAIs in unmetamorphosed (petrologic type 2-3.0) chondrites have close-to-solar $\Delta^{17} \mathrm{O}$ (deviation from the terrestrial fractionation line, $=\delta^{17} \mathrm{O}-0.52 \times \delta^{18} \mathrm{O}$ ), $\sim-24 \pm 2 \%$ (e.g., Yurimoto et al. 2008; Makide et al. 2009; McKeegan et al. 2011; Bodénan et al. 2014; Kööp et al. 2016; Ushikubo et al. 2017; Krot 2019 and references therein). In contrast, refractory inclusions in the metasomatically altered and metamorphosed $\mathrm{CV}$ chondrites of petrologic type $\geq 3.1$ have heterogeneous $\Delta^{17} \mathrm{O}$ : spinel, hibonite, forsterite, and most $\mathrm{Al}, \mathrm{Ti}$-diopside grains have solar-like $\Delta^{17} \mathrm{O}(\sim-24 \pm 2 \%$ ), whereas melilite, anorthite, and, occasionally, Ti-rich pyroxenes are ${ }^{16} \mathrm{O}$-depleted to various degrees $\left(\Delta^{17} \mathrm{O}\right.$ range from $\sim-24$ to $\sim-1 \%$ ) (Clayton et al. 1977; MacPherson et al. 2017; Kawasaki et al. 2018). Bulk oxygen-isotope compositions of CAIs and their mineral separates from the CV3.6 chondrite Allende (Bonal et al. 2006) follow a mass-independent fractionation line with a slope of 0.94 , named the Carbonaceous Chondrite Anhydrous Mineral (CCAM) line (Clayton et al. 1977). The nature of this oxygen isotopic heterogeneity and the nature of the CCAM line remain controversial. They may reflect gas-melt O-isotope exchange during incomplete melting of coarse-grained igneous CAI precursors in the nebular gas of variable oxygen isotopic composition (e.g., Yurimoto et al. 1998; Kawasaki et al. 2018). Alternatively or in addition to these nebular processes, the CV CAIs could have experienced mineralogically controlled O-isotope exchange during aqueous fluid-rock interaction on the $\mathrm{CV}$ chondrite parent asteroid that largely affected their anorthite, melilite, perovskite, grossite, and $\mathrm{Zr}$ - and Sc-rich oxides and silicates (e.g., Wakaki et al. 2013; Krot et al. 2008, 2019a, 2019b, 2019c). We note that chondrules and refractory inclusions from the least altered carbonaceous chondrite Acfer 094 (C3.0 ungrouped) have uniform oxygen isotopic compositions and on a three-isotope oxygen diagram plot along the line having a slope of $0.987 \pm 0.013$, named the Primitive Chondrule Mineral (PCM) line (Ushikubo et al. 2012, 2017), which is different from the CCAM line.

In order to understand the nature (place, time, and mechanism) of metasomatic alteration of the CV CAIs and its possible effect on their O-isotope heterogeneity, we report here on the mineralogy, petrography, and in situ measured O-isotope compositions of secondary minerals in all major types of the Allende coarse-grained igneous CAIs (CTA, B1, B2, FoB, and C; Table 1) using the UH Cameca ims-1280 and matrix-matched standards. For classification of the CV coarse-grained CAIs, see MacPherson (2014) and references therein. Aluminum-magnesium isotope systematics was measured in grossular of several type B1 CAIs.

Preliminary results of this study have been previously reported by Brearley and Krot (2013) and Krot et al. (2010, 2020a).

\section{Previous studies}

The $\mathrm{Al}-\mathrm{Mg}$ and $\mathrm{O}$ isotopic compositions of secondary minerals in Allende CAIs have been previously reported in several papers and abstracts. In this section, we briefly summarize the major results obtained and interpretations proposed in these publications. Secondary minerals, their chemical formulae, and abbreviations used in the paper are listed in Table 2.

Wark (1981) described pockets of secondary alteration minerals enriched in $\mathrm{Na}, \mathrm{K}, \mathrm{Rb}, \mathrm{Cl}, \mathrm{I}, \mathrm{Fe}$, and $\mathrm{Zn}$,

Table 1 A list of coarse-grained igneous CAls from Allende studied here and compositional ranges of their melilites

\begin{tabular}{|c|c|c|c|c|}
\hline CAI & Type & Åk, mol\% & $\mathrm{Na}_{2} \mathrm{O}, \mathrm{wt} \%$ & Ref. \\
\hline ALH-2 & FTA/CTA & $1-24$ & n.d. & [1] \\
\hline $818-G$ & CTA & $12-27$ & n.d. & [2] \\
\hline CG-13/15 & CTA & $3-32$ & n.d. & [2] \\
\hline$T S-2$ & CTA & $9-65$ & Up to 0.15 & [3] \\
\hline TS-68 & CTA & $8-33$ & Up to 0.18 & {$[2,4]$} \\
\hline AJEF & B1 & $12-61$ & Up to 0.19 & [2] \\
\hline Big-All & B1 & n.a. & & [2] \\
\hline Egg-3 & B1 & n.a. & & [2] \\
\hline TS-23 & B1 & $10-72$ & Up to 0.30 & {$[2,6]$} \\
\hline TS-34 & B1 & $10-65$ & Up to 0.30 & {$[2,6]$} \\
\hline$A-39$ & B2 & n.a. & & [2] \\
\hline 2 & B2 & $9-55$ & Up to 0.17 & {$[2,7]$} \\
\hline $3529 Z$ & & B2 & n.a. & [2] \\
\hline CG-6 & B2 & $13-75$ & Up to 0.20 & [2] \\
\hline CG-10 & B2 & $10-74$ & Up to 0.25 & [2] \\
\hline CG-11 & B2 & n.a. & n.a. & [2] \\
\hline TS-21 & B2 & $10-75$ & Up to 0.30 & {$[2,6]$} \\
\hline TS-31 & B2 & $76-87$ & $0.10-0.20$ & [2] \\
\hline All-2 & FoB & $79-87$ & $0.12-0.23$ & [2] \\
\hline All-5-2 & FoB & $66-90$ & & {$[2,5]$} \\
\hline 100 & C & $58-74$ & $0.15-0.25$ & {$[8,9]$} \\
\hline 160 & $C$ & $44-72$ & Up to 0.36 & {$[8,9]$} \\
\hline
\end{tabular}

References: [1] Simon et al. (2001); [2] this study; [3] Simon et al. (1998); [4] Simon et al. (1999); [5] Bullock et al. (2012); [6] Simon and Grossman (2006); Kawasaki et al. (2018); [7] Ushikubo et al. (2007); [8] Wark et al. (1987); [9] Krot et al. (2007b) 
Table 2 A partial list of secondary minerals in the Allende coarse-grained igneous CAls, their formulae, and abbreviations used in the text

\begin{tabular}{|c|c|}
\hline Mineral/abbreviation & Chemical formula \\
\hline Adrianite & $\mathrm{Ca}_{12}\left(\mathrm{Al}_{4} \mathrm{Mg}_{3} \mathrm{Si}_{7}\right) \mathrm{O}_{32} \mathrm{Cl}_{6}$ \\
\hline Anorthite/an & $\mathrm{CaAl}_{2} \mathrm{Si}_{2} \mathrm{O}_{8}$ (tricl.) \\
\hline Andradite/andr & $\mathrm{Ca}_{3} \mathrm{Fe}_{2} \mathrm{Si}_{3} \mathrm{O}_{12}$ \\
\hline Awaruite & $\mathrm{Ni}_{3} \mathrm{Fe}$ \\
\hline Beckettite & $\mathrm{Ca}_{2}(\mathrm{~V}, \mathrm{Al}, \mathrm{Ti}, \mathrm{Mg})_{6} \mathrm{Al}_{6} \mathrm{O}_{20}$ \\
\hline Calcite/cal & $\mathrm{CaCO}_{3}$ \\
\hline Celsian/cls & $\mathrm{BaAl}_{2} \mathrm{Si}_{2} \mathrm{O}_{8}$ \\
\hline Clintonite/cln & $\mathrm{Ca}(\mathrm{Mg}, \mathrm{Al})_{3}\left(\mathrm{Al}_{3} \mathrm{Si}\right) \mathrm{O}_{10}(\mathrm{OH})_{2}$ \\
\hline Corundum/cor & $\mathrm{Al}_{2} \mathrm{O}_{3}$ \\
\hline Coulsonite & $(\mathrm{Fe}, \mathrm{Mg})(\mathrm{V}, \mathrm{Al})_{2} \mathrm{O}_{4}$ \\
\hline Diopside-Ca-Tschermakite $_{s s}$ & $\mathrm{CaMgSiO}_{6}-\mathrm{CaAl}_{2} \mathrm{SiO}_{6}$ \\
\hline Dmisteinbergite/dms & $\mathrm{CaAl}_{2} \mathrm{Si}_{2} \mathrm{O}_{8}$ (hex.) \\
\hline Forsterite/fo & $\mathrm{Mg}_{2} \mathrm{SiO}_{4}$ \\
\hline Grossular/grs & $\mathrm{Ca}_{3} \mathrm{Al}_{2} \mathrm{Si}_{3} \mathrm{O}_{12}$ \\
\hline Heazlewoodite/hzw & $\mathrm{Ni}_{3} \mathrm{~S}_{2}$ \\
\hline Hedenbergite/hed & $\mathrm{CaFeSi}_{2} \mathrm{O}_{6}$ \\
\hline Hercynite & $(\mathrm{Fe}, \mathrm{Mg}) \mathrm{Al}_{2} \mathrm{O}_{4}$ \\
\hline Hutcheonite/htc & $\mathrm{Ca}_{3} \mathrm{Ti}_{2} \mathrm{Si}_{3} \mathrm{O}_{12}$ \\
\hline Ilmenite & $\mathrm{FeTiO}_{3}$ \\
\hline Kaolinite & $\mathrm{Al}_{2} \mathrm{Si}_{2} \mathrm{O}_{5}(\mathrm{OH})_{4}$ \\
\hline Magnetite/mgt & $\mathrm{Fe}^{2+} \mathrm{Fe}^{3+}{ }_{2} \mathrm{O}_{4}$ \\
\hline Margarite/mrg & $\mathrm{CaAl}_{2}\left(\mathrm{Al}_{2} \mathrm{Si}_{2}\right) \mathrm{O}_{10}(\mathrm{OH})_{2}$ \\
\hline Molybdenite & $\mathrm{MoS}_{2}$ \\
\hline Monticellite/mnl & $\mathrm{Ca}(\mathrm{Mg}, \mathrm{Fe}) \mathrm{SiO}_{4}$ \\
\hline Montmorillonite & $(\mathrm{Na}, \mathrm{Ca})_{0.3}(\mathrm{Al}, \mathrm{Mg})_{2} \mathrm{Si}_{4} \mathrm{O}_{10}(\mathrm{OH}) \cdot 2 \mathrm{n}\left(\mathrm{H}_{2} \mathrm{O}\right)$ \\
\hline Na-melilite/Na-mel & $(\mathrm{CaNa})_{2}(\mathrm{Al}, \mathrm{Mg})\left[(\mathrm{AlSi})_{2} \mathrm{O}_{7}\right]$ \\
\hline Nepheline/nph & $\mathrm{NaAlSiO}_{4}$ \\
\hline Ferromagnesian olivine/ol & $(\mathrm{Fe}, \mathrm{Mg})_{2} \mathrm{SiO}_{4}$ \\
\hline Pentlandite/pnt & $(\mathrm{Fe}, \mathrm{Ni})_{9} \mathrm{~S}_{8}$ \\
\hline Scheelite & $\mathrm{Ca}\left(\mathrm{WO}_{4}\right)$ \\
\hline Sodalite/sod & $\mathrm{Na}_{8} \mathrm{Al}_{6} \mathrm{Si}_{6} \mathrm{O}_{24} \mathrm{Cl}_{2}$ \\
\hline Sphene & $\mathrm{CaTiSiO}_{5}$ \\
\hline Spinel/sp & $(\mathrm{Mg}, \mathrm{Fe}) \mathrm{Al}_{2} \mathrm{O}_{4}$ \\
\hline Tilleyite/tlt & $\mathrm{Ca}_{5} \mathrm{Si}_{2} \mathrm{O}_{7}\left(\mathrm{CO}_{3}\right)_{2}$ \\
\hline Vesuvianite & $\mathrm{Ca}_{10} \mathrm{Mg}_{2} \mathrm{Al}_{4}\left(\mathrm{SiO}_{4}\right)_{5}\left(\mathrm{Si}_{2} \mathrm{O}_{7}\right)_{2}(\mathrm{OH})_{4}$ \\
\hline Wadalite/wad & $\mathrm{Ca}_{12} \mathrm{Al}_{10} \mathrm{Si}_{4} \mathrm{O}_{32} \mathrm{Cl}_{6}$ \\
\hline Wollastonite/wol & $\mathrm{CaSiO}_{3}$ \\
\hline
\end{tabular}

including Fe-bearing grossular, plagioclase $\left(\mathrm{An}_{90-100}\right)$, nepheline, sodalite, Fe-bearing spinel, andradite, and olivine and pyroxenes of variable compositions in several Allende CAIs. Wark (1981) concluded that the alteration affected largely melilite and resulted in formation of grossular and anorthite followed by crystallization of nepheline and sodalite, and diffusion of iron into spinel. Based on the presence of alkali-rich halos around the CAIs, which were interpreted as evidence for outward diffusion of $\mathrm{Na}$ and K, Wark (1981) concluded that alteration occurred in the solar nebula prior to incorporation of CAIs into the Allende meteorite.

Hutcheon and Newton (1981) described secondary minerals in the Allende Type B1 CAIs TS-23 and TS-34. They showed that secondary grossular and monticellite form narrow veins separating primary melilite and anorthite crystals, and occasionally form a corona completely surrounding large melilite grains; bladed wollastonite crystals fill cavities lined with grossular. Hutcheon and Newton (1981) attributed formation of the grossular -monticellite assemblages to thermal decomposition of melilite at $\sim 670{ }^{\circ} \mathrm{C}$ in the solar nebula:

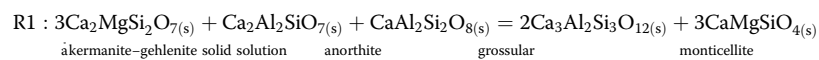

No resolvable excess of radiogenic ${ }^{26} \mathrm{Mg}\left({ }^{26} \mathrm{Mg}^{*}\right)$ was found in grossular and sodalite: the upper limits on the initial ${ }^{26} \mathrm{Al} /{ }^{27} \mathrm{Al}$ ratio $\left.\left[{ }^{26} \mathrm{Al} /{ }^{27} \mathrm{Al}\right)_{0}\right]$ are $<4.4 \times 10^{-6}$ and $<1 \times 10^{-6}$, respectively, suggesting the alteration occurred $>2.4$ and $>$ 3.9 Ma after crystallization of the host CAIs characterized by approximately the canonical $\left({ }^{26} \mathrm{Al} /{ }^{27} \mathrm{Al}\right)_{0}$ of $\sim 4.5 \times 10^{-5}$.

Tomeoka and Buseck (1982) reported intergrown mica and montmorillonite in a fine-grained CAI from Allende, but proposed no mechanism of their formation.

Hashimoto and Grossman (1987) and McGuire and Hashimoto (1989) described secondary grossular, anorthite, feldspathoids, ilmenite, ferroan olivine, andradite, salite-hedenbergite pyroxenes, and phyllosilicates (a mixture of Na-phlogopite and chlorite or Al-rich serpentine) in AOAs and several coarse- and fine-grained CAIs from Allende. These authors concluded that the Allende refractory inclusions experienced an open-system alteration in the cooling solar nebula (from $~ 1000$ to $~ 350$ $\mathrm{K}): \mathrm{Si}, \mathrm{Na}, \mathrm{K}, \mathrm{Fe}, \mathrm{Cr}, \mathrm{Cl}$, and $\mathrm{H}_{2} \mathrm{O}$ were introduced, whereas $\mathrm{Ca}$ was lost, presumably as gaseous $\mathrm{Ca}(\mathrm{OH})_{2}$. Magnesium may have been lost during the replacement of melilite by anhydrous minerals and subsequently added during the formation of phyllosilicates.

Keller and Buseck (1991) described secondary micas, clintonite, and margarite in an Allende CTA CAI. Clintonite crystals, $10-500 \mathrm{~nm}$ in size, partially replace grossular in alteration veins crosscutting gehlenitic melilite $\left(\AA \mathrm{k}_{10-20}\right)$, whereas margarite occurs as lamellae intergrown with secondary anorthite replacing melilite. Keller and Buseck concluded that the micas formed by hydration reactions below $450 \mathrm{~K}$ in the solar nebula: 


$$
\begin{aligned}
& \mathrm{R} 2: \underset{\text { anorthite }}{2 \mathrm{CaAl}_{2} \mathrm{Si}_{2} \mathrm{O}_{8(\mathrm{~s})}}+\mathrm{H}_{2} \mathrm{O}_{(\mathrm{g})}= \\
& \underset{\text { margarite }}{\mathrm{CaAl}_{2}\left(\mathrm{Al}_{2} \mathrm{Si}_{2}\right) \mathrm{O}_{10}(\mathrm{OH})_{2(\mathrm{~s})}}+\mathrm{CaO}_{(\mathrm{g})}+2 \mathrm{SiO}_{2(\mathrm{~g})}
\end{aligned}
$$

$$
\begin{aligned}
& \mathrm{R} 3: \underset{\text { grossular }}{2 \mathrm{Ca}_{3} \mathrm{Al}_{2} \mathrm{Si}_{3} \mathrm{O}_{12}}+2 \mathrm{MgAl}_{2} \mathrm{O}_{4(\mathrm{~g})}+\underset{\text { spinel }}{2 \mathrm{Fe}_{(\mathrm{g})}}+3 \mathrm{H}_{2} \mathrm{O}_{(\mathrm{g})}= \\
& \underset{\text { clintonite }}{\mathrm{Ca}\left(\mathrm{Mg}_{2} \mathrm{Al}\right)\left(\mathrm{Al}_{3} \mathrm{Si}\right) \mathrm{O}_{10}(\mathrm{OH})_{2}}+2 \mathrm{FeAl}_{2} \mathrm{O}_{4(\mathrm{~s})}+\underset{\text { hercynite }}{5 \mathrm{CaO}_{(\mathrm{g})}}+5 \mathrm{SiO}_{2(\mathrm{~g})}+2 \mathrm{H}_{2}(\mathrm{~g})
\end{aligned}
$$

Davis et al. (1994) reported on the mineralogy, petrography, trace element abundances, and $\mathrm{Al}-\mathrm{Mg}$ isotope systematics of primary and secondary minerals in TS-23 and TS-34. Bulk chemical compositions, trace element abundances, and textures suggest that alteration is dominated by a reaction of $\mathrm{Mg}$-rich melilite with $\mathrm{SiO}_{2}$; a reaction of melilite and anorthite also occurred, as did a loss of $\mathrm{Sr}$ and gain of volatiles. Melilite mantles of $T S-23$ and TS-34 are only slightly altered and contain mainly grossular veins, whereas larger patches of secondary grossular, monticellite, and wollastonite occur between partially altered grains of anorthite and åkermanitic melilite $\left(\AA_{k_{72-76}}\right)$ in the CAI cores, suggesting that Mgrich melilite is more easily altered than gehlenitic melilite; fassaite and spinel show no evidence for alteration. No detectable ${ }^{26} \mathrm{Mg}^{*}$ was found in grossular; primary anorthite in altered zones shows evidence for disturbed $\mathrm{Al}-\mathrm{Mg}$ isotope systematics. The rare earth element patterns of altered zones are similar to those of adjacent late-crystallized melilite. The altered zones are enriched in $\mathrm{B}, \mathrm{F}, \mathrm{Na}, \mathrm{K}, \mathrm{Cl}$, and $\mathrm{Pb}$ relative to the adjacent primary phases; they are also fairly high in $\mathrm{Sr}, \mathrm{Ba}$, and $\mathrm{Eu}$. The altered zones appear to have inherited their trace element abundances from melilite; $\mathrm{Sr}$ was lost in varying degrees relative to Ba and Eu. Davis et al. (1994) concluded the alteration occurred in the solar nebula.

Hiyagon (1998) reported $\delta^{17} \mathrm{O}$ and $\delta^{18} \mathrm{O}$ with large uncertainties $\left(2 \sigma\right.$ for $\delta^{17} \mathrm{O}$ and $\delta^{18} \mathrm{O}$ are $\sim 3-4$ and $4-9 \%$, respectively) of secondary grossular $(-12$ to $-4 \%$ and -6 to $+2 \%$, respectively; $\Delta^{17} \mathrm{O} \sim-9$ to $-5 \%$ ) replacing melilite and anorthite, and of wollastonite, andradite, and hedenbergite $\left(-3\right.$ to $+4 \%$ and +2 to $+10 \%$; $\Delta^{17} \mathrm{O} \sim-4$ to $-1 \%$ o) in cavities and topographic depressions on the surface of several coarse-grained Allende CAIs. No matrix-matched standards were used in this study (San Carlos olivine was used as a standard for all secondary minerals). As matrix effects could not have been properly corrected, only $\Delta^{17} \mathrm{O}$ can be trusted.

Ushikubo et al. (2007) reported ${ }^{36} \mathrm{Cl}^{36} \mathrm{~S},{ }^{26} \mathrm{Al}-{ }^{26} \mathrm{Mg}$, and oxygen isotopic systematics of secondary minerals (San Carlos olivine was used as a standard) in the Allende Type B2 CAI 2. Two secondary mineral domains were identified: "ragged" anorthite-grossular domain in the CAI interior and sodalite-anorthitenepheline-ferroan olivine domain in its outer part. $\Delta^{17} \mathrm{O}$ of ragged anorthite and grossular (SIMS spots in grossular overlapped with primary fassaite and spinel) range from -17 to $-9 \pm 6 \%$. Sodalite and anorthite in the $\mathrm{Na}$ rich domain and primary melilite appear to be slightly ${ }^{16} \mathrm{O}$-depleted $\left(\Delta^{17} \mathrm{O} \sim-7 \pm 6 \%\right)$. No resolvable ${ }^{26} \mathrm{Mg}^{*}$ $\left[\left({ }^{26} \mathrm{Al} /{ }^{27} \mathrm{Al}\right)_{0}<4.4 \times 10^{-7}\right]$ is observed in grossular, lathshaped anorthite, and sodalite. In contrast, the inferred $\left({ }^{26} \mathrm{Al} /{ }^{27} \mathrm{Al}\right)_{0}$ in ragged anorthite is $(1.2 \pm 0.2) \times 10^{-5}$. Ushikubo et al. (2007) interpreted these observations as an evidence for multiple alteration events experienced by the CAI, 1.5 and 5.7 Ma after its crystallization.

Fagan et al. (2007) studied several type B1, B2, CTA, and fluffy type A (FTA) CAIs from Allende and identified two textural and mineralogic types (domains) of secondary mineralization: a grossular-rich domain concentrated along melilite grain boundaries in CAI interiors and a feldspathoid-bearing domain confined mostly to CAI margins, just interior to the WarkLovering rim sequence. In type B1s, most secondary minerals, and some secondary minerals in other CAI types, show no resolvable ${ }^{26} \mathrm{Mg}^{*}$, suggesting formation > 3 Ma after primary CAI minerals. All but two analyses of secondary minerals from the FTA CAI yield $\left({ }^{26} \mathrm{Al} /{ }^{27} \mathrm{Al}\right)_{0} \sim(4.9 \pm 2.8) \times 10^{-6}$, suggesting formation 1.8-3.2 Ma after the primary CAI minerals. One grossular from the Type B2 CAI, and several grossular and feldspar analyses from a CTA CAI, have ${ }^{26} \mathrm{Mg}^{*}$ consistent with $\left({ }^{26} \mathrm{~A} /{ }^{27} \mathrm{Al}\right)_{0} \sim 4.5 \times 10^{-5}$. Fagan et al. (2007) suggested that Allende CAIs experienced a protrackted, episodic alteration: some alteration occurred during the formation of CAIs; some continued during melting events associated with chondrule formation in the solar nebula and/or on the $C V$ parent asteroid.

Ford and Brearley (2008) described secondary anorthite, grossular, nepheline, and sodalite replacing melilite in a Type A CAI from Allende. The CAI is surrounded by an aureole of $\mathrm{Ca}, \mathrm{Fe}$-rich pyroxenes and andradite. Ford and Brearley (2008) concluded that $\mathrm{Na}, \mathrm{Cl}$, and $\mathrm{Si}$ were introduced into the CAI, whereas Ca was lost during metasomatic alteration. Mass-balance calculations show that amount of $\mathrm{Ca}$ lost is sufficient to explain $\mathrm{Ca}$ in the $\mathrm{Ca}, \mathrm{Fe}$-rich aureole, suggesting that the alteration occurred in situ on the CV parent asteroid. Subsequently, Brearley et al. (2014) described dmisteinbergite associated with disordered biopyriboles replacing melilite in this CAI, indicating the formation of the secondary minerals in the presence of an aqueous fluid.

Che and Brearley (2021) described secondary mineralization in a Type C CAI from Allende. Primary anorthite in this inclusion is pseudomorphically replaced by sodalite, nepheline, and ferroan olivine $\left(\mathrm{Fa}_{48}\right)$; secondary hedenbergite, diopside, and wollastonite occur in 
nodules. Sodalite is more abundant in the core of the CAI, whereas nepheline is more abundant in its mantle. According to Che and Brearley (2021), the zoned distribution of $\mathrm{Na}$ - and $\mathrm{Cl}$-bearing phases may either reflect a two-stage alteration process on the $\mathrm{CV}$ parent asteroid or evolution of the fluid composition during the alteration.

\section{Analytical methods}

\subsection{Mineralogy and petrology}

Polished sections of the Allende CAIs provided by ${ }^{1} \mathrm{Da}$ vid Wark (Australian National University), Gerald Wasserburg (California Institute of Technology), Ian Hutcheon (Lawrence Livermore National Laboratory), and Steven Simon (University of Chicago) were mapped in $\mathrm{Mg}, \mathrm{Ca}, \mathrm{Al}, \mathrm{Ti}, \mathrm{Na}, \mathrm{Cl}, \mathrm{Si}, \mathrm{S}, \mathrm{Ni}$, and $\mathrm{Fe} \mathrm{K} \propto$-rays using a 5-10 $\mu \mathrm{m}$ electron beam, $15 \mathrm{kV}$ accelerating voltage, $50 \mathrm{nA}$ beam current, $10-20 \mathrm{~ms}$ per pixel acquisition time, and resolution of $5-10 \mu \mathrm{m}$ per pixel with wavelength-dispersive spectrometer detectors with the University of Hawai'i (UH) field-emission electron microprobe JEOL JXA-8500F. Elemental maps in $(i) \mathrm{Mg}$, $\mathrm{Ca}$, and $\mathrm{Al}$, and $(\mathrm{ii}) \mathrm{Cl}, \mathrm{Na}$, and $\mathrm{Al}$ were combined using an RGB-color scheme (Mg, or $\mathrm{Cl}-$ red, $\mathrm{Ca}$ or $\mathrm{Na}$-green, and $\mathrm{Al}-$ blue). The $\mathrm{MgCaAl}$ maps are used to illustrate textures and primary mineralogy of the Allende CAIs studied. In these maps, spinel is purple; melilite and most secondary minerals, which typically replace melilite, are bright-green; $\mathrm{Al}, \mathrm{Ti}$-diopside is dark-green; anorthite is dark-blue; and forsterite is red. The $\mathrm{ClNaAl}$ maps are used to illustrate distribution of adrianite/ wadalite (red), sodalite (yellow), and nepheline (green) inside and outside CAIs. All CAIs were subsequently studied in backscattered electron (BSE) images and analyzed for chemical compositions using the UH JEOL JXA-8500F. Quantitative wavelength-dispersive analyses were obtained at $15 \mathrm{kV}$ with counting times of $30 \mathrm{~s}$ for peak and for background measurements for each analysis. Natural minerals were used as standards. Electron probe data were reduced via the modified ZAF correction procedure PAP (Pouchou and Pichoir 1984).

Representative chemical compositions of secondary minerals in the Allende igneous CAIs are listed in Supplementary Material (Table EA1). X-ray elemental maps and backscattered electron (BSE) images of the representative Allende CAIs studied are shown in Figs. 1, 2, 3, 4, $5,6,7,8,9,10,11$, and 12 .

\subsection{Oxygen isotopes}

Oxygen isotopic compositions were analyzed in situ with the UH Cameca ims-1280 ion microprobe using the

${ }^{1}$ David Wark, Gerald Wasserburg, and Ian Hutcheon are deceased method of Nagashima et al. (2015). Briefly, a primary $\mathrm{Cs}^{+}$ion beam of $\sim 25 \mathrm{pA}$ focused to $\sim 1-2 \mu \mathrm{m}$ was used. The ion microprobe was operated at $-10 \mathrm{keV}$ with a 50 $\mathrm{eV}$ energy window. Three oxygen isotopes were measured simultaneously: ${ }^{16} \mathrm{O}^{-}$was measured on a Faraday cup (FC) and ${ }^{17} \mathrm{O}^{-}$and ${ }^{18} \mathrm{O}^{-}$were measured on electron multipliers (EMs). The mass resolving power $(\mathrm{m} / \Delta \mathrm{m})$ for ${ }^{16} \mathrm{O}^{-}$and ${ }^{18} \mathrm{O}^{-}$was $\sim 2000$, and that for ${ }^{17} \mathrm{O}^{-}$was $\sim 5500$, sufficient to separate interfering ${ }^{16} \mathrm{OH}^{-}$. A normal-incidence electron flood gun was used for charge compensation. ${ }^{16} \mathrm{OH}^{-}$signal was monitored after each measurement. The contribution of ${ }^{16} \mathrm{OH}^{-}$onto ${ }^{17} \mathrm{O}^{-}$was corrected based on a peak/tail ratio. The correction was typically less than $0.05 \%$. Instrumental fractionation was corrected using terrestrial standards including San Carlos olivine (for melilite, Na-melilite, forsterite, and ferroan olivine), augite (for Al-diopside and kushiroite), Burma spinel (for spinel), Miyake-jima anorthite (for anorthite and dmisteinbergite), andradite (for andradite), sodalite (for sodalite), nepheline (for nepheline), calcite (for calcite), wollastonite (for wollastonite), and grossular (for grossular) (Nagashima et al. 2020). To verify the positions of the sputtered regions, the spots analyzed for oxygen isotopes were studied with secondary and BSE images using the UH JEOL JXA-8500F electron microprobe before and after SIMS measurements. Oxygenisotope compositions are reported as $\delta^{17} \mathrm{O}$ and $\delta^{18} \mathrm{O}$, deviations from Vienna Standard Mean Ocean Water $\left(\right.$ VSMOW; ${ }^{17} \mathrm{O} /{ }^{16} \mathrm{O}_{\text {VSMOW }}=0.000380 ;{ }^{18} \mathrm{O} /{ }^{16} \mathrm{O}_{\text {VSMOW }}=$ 0.002005; De Laeter et al. 2003) in parts per thousand: $\delta^{17,18} \mathrm{O}_{\text {SMOW }}=\left[\left({ }^{17,18} \mathrm{O} /{ }^{16} \mathrm{O}_{\text {sample }}\right) /\left({ }^{17,18} \mathrm{O} /{ }^{16} \mathrm{O}_{\text {VSMOW }}\right)\right.$ $-1] \times 1000$, and as deviation from the terrestrial fractionation (TF) line, $\Delta^{17} \mathrm{O}$. Typical uncertainties for $\delta^{17} \mathrm{O}$, $\delta^{18} \mathrm{O}$, and $\Delta^{17} \mathrm{O}$ were $\sim 1.5,2$, and $2 \%$, respectively.

Oxygen isotopic compositions of the primary and secondary minerals in the Allende coarse-grained igneous CAIs measured here and plotted in Fig. 13a-d are listed in Supplementary Material (Tables EA2 and EA3, respectively).

\subsection{Aluminum-magnesium isotope systematics}

Aluminum and magnesium isotopic compositions of grossular were measured with the UH Cameca ims- 1280 using the method of Jacobsen et al. (2011). Briefly, a primary ${ }^{16} \mathrm{O}^{-}$ion beam with a current of $\sim 150 \mathrm{pA}$ focused to $\sim 5 \times 7 \mu \mathrm{m}^{2}$ was used. ${ }^{24} \mathrm{Mg}^{+},{ }^{25} \mathrm{Mg}^{+}$, and ${ }^{26} \mathrm{Mg}^{+}$were measured sequentially using a monocollector EM. ${ }^{27} \mathrm{Al}^{+}$ was measured using a multicollection FC simultaneously with ${ }^{25} \mathrm{Mg}^{+}$. The mass-resolving power was set to $\sim 3800$, sufficient to separate interfering hydrides and doubly charged ${ }^{48} \mathrm{Ca}^{2+}$. The ${ }^{27} \mathrm{Al}^{+} /{ }^{24} \mathrm{Mg}^{+}$ratios were corrected using a sensitivity factor determined on a terrestrial grossular standard. 


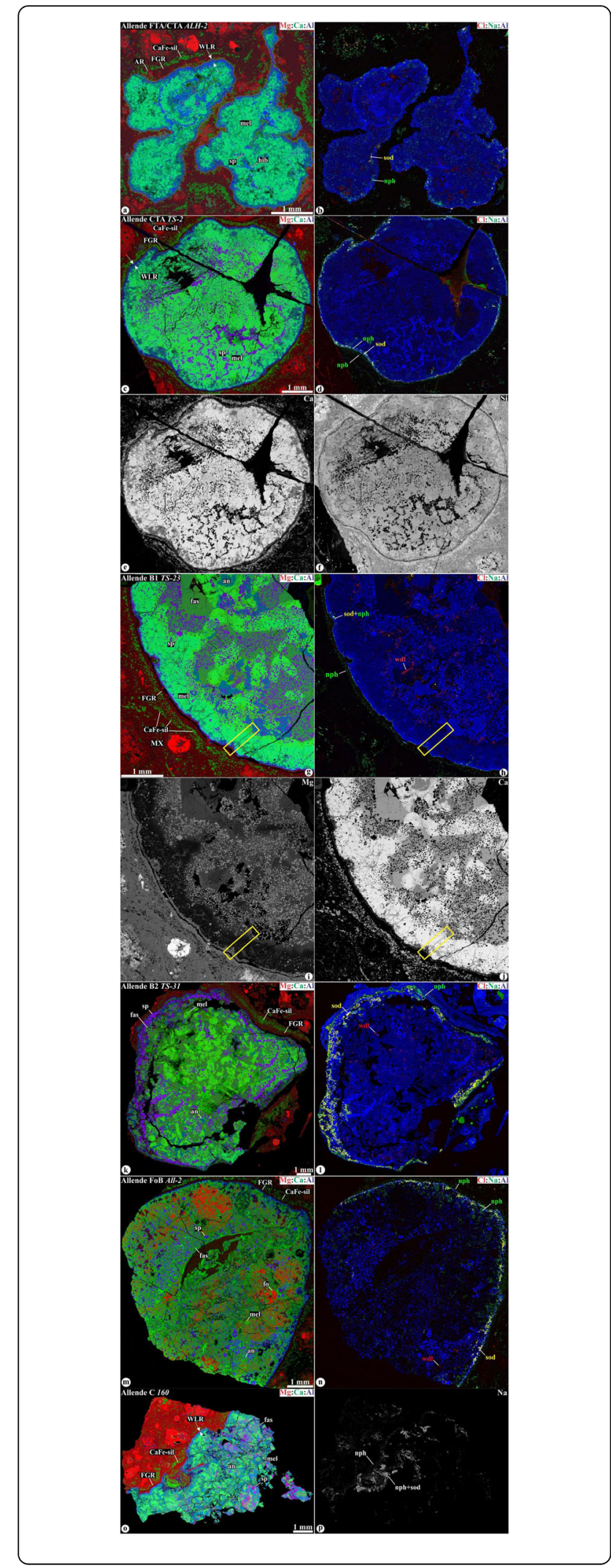

Fig. 1 Combined $x$-ray elemental maps in $(\mathbf{a}, \mathbf{c}, \mathbf{g}, \mathbf{k}, \mathbf{m}, \mathbf{o}) \mathrm{Mg}(\mathrm{red})$, $\mathrm{Ca}$ (green), and $\mathrm{Al}$ (blue), (b, d, h, l, n) Cl (red), Na (green), and Al (blue) and elemental maps in (e, j) $\mathrm{Ca}$, (f) Si, (j) Mg, and (p) Na of representative samples of coarse-grained CAls from the CV3 carbonaceous chondrites Allende studied: ALH2 (FTA/CTA), TS2 (CTA), TS23 (B1), TS31 (B2), Al-2 (FoB), and 160 (C). Regions outlined in "g-j" are shown in detail in Fig. X. All CAls are surrounded by Wark-

Lovering rims (WLR), fine-grained matrix-like rims (FGR), and a layer of Ca,Fe-rich silicates (CaFe-sil). Nepheline and sodalite are concentrated in the peripheral portions of CAls. Abundant nepheline grains occur also in fine-grained matrix-like rims. Wadalite/adrianite are found exclusively in cores of Type B CAls (high $\mathrm{Cl}$ signal in $\mathbf{b}$ comes from epoxy). fas = Al,Ti-diopside; mel = melilite. Hereafter: abbreviations of secondary minerals are listed in Table 1

Magnesium isotopic compositions of melilite were measured simultaneously using 4. FCs. A $\sim 10 \mathrm{nA}{ }^{16} \mathrm{O}^{-}$ ion beam with $\sim 20 \mu \mathrm{m}$ size was used. The massresolving power was set to $\sim 3800$ using an exit slit width of $250 \mu \mathrm{m}$ (multicollection exit slit \#2). The count rates of ${ }^{24} \mathrm{Mg}^{+}$ranged from $\sim 1 \times 10^{7}$ to $5 \times 10^{7}$ cps. The instrumental mass-fractionation effects and relative sensitivities were corrected using synthetic melilite glass. Excesses of ${ }^{26} \mathrm{Mg}\left({ }^{26} \mathrm{Mg}^{*}\right)$ were determined using an exponential law with an exponent of 0.514 . We note differences in ${ }^{26} \mathrm{Mg}^{*}$ calculated using exponents of 0.514 and 0.5128 (Davis et al. 2015) are negligibly small $(<0.03 \%)$.

\section{Results and discussion}

\subsection{Petrography and primary mineralogy of the Allende coarse-grained igneous CAls}

Based on the mineralogy, petrography, and bulk chemical compositions, several types of coarse-grained igneous CAIs are recognized in CV chondrites: compact type A (CTA), Type B (B1, B2), forsterite-bearing type B (FoB), and type C (e.g., Grossman 1980; Wark 1987; Wark et al. 1987; Simon et al. 1999; Simon and Grossman 2006; Bullock et al. 2012). Bulk chemical compositions of these CAIs projected from spinel onto the gehlenite $\left(\mathrm{Ca}_{2} \mathrm{Al}_{2} \mathrm{SiO}_{7}\right)$-forsterite $\left(\mathrm{Mg}_{2} \mathrm{SiO}_{4}\right)$-anorthite $\left(\mathrm{CaAl}_{2} \mathrm{Si}_{2} \mathrm{O}_{8}\right)$ plane of the $\mathrm{CaO}-\mathrm{MgO}-\mathrm{Al}_{2} \mathrm{O}_{3}-\mathrm{SiO}_{2}$ (CMAS) system plot in the liquidus fields of melilite (CTA, B1, and B2; $\mathrm{B} 2$ s are generally more $\mathrm{SiO}_{2}$-rich than $\mathrm{B} 1 \mathrm{~s})$, forsterite $(\mathrm{FoB})$, and anorthite $(\mathrm{C})$.

In this section, we characterize the petrography and primary mineralogy of representative members of different CAI types studied (Fig. 1). Other Allende CAIs studied, their classification, and variations in chemical compositions of their melilite, one of the major silicate minerals that experienced metasomatic alteration, are listed in Table 1.

\subsubsection{Type A CAls}

Type $\mathrm{A} \mathrm{Ca}, \mathrm{Al}$-rich inclusions are a major type of coarsegrained refractory inclusions in CV3 chondrites. Type A 


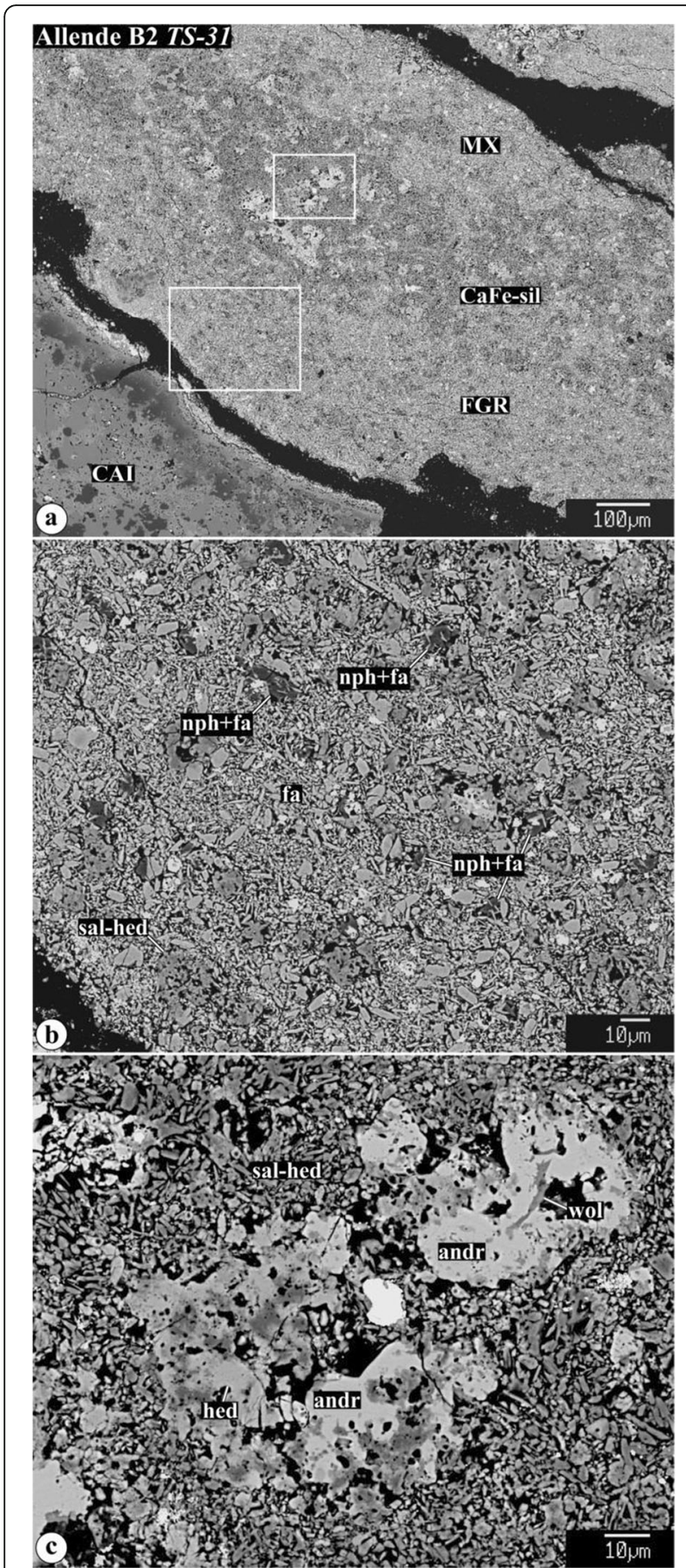

Fig. 2 Backscattered electron images of a fine-grained matrix-like rim and a Ca,Fe-rich silicate layer around Type B2 CAI TS31. The matrix-like rim consists predominantly of lath-shaped ferroan olivine, nepheline, and salite-hedenbergite pyroxene nodules. The Ca,Fe-rich silicate layer is composed of salite-hedenbergite pyroxenes, andradite, and wollastonite
CAIs, originally defined by Grossman (1975) as extremely melilite-rich inclusions with minor spinel and $\mathrm{Al}$,Ti-diopside, were subsequently subdivided into irregularly shaped, fluffy ones (FTA), and round, compact (CTA) ones (Grossman 1980). Fluffy Type A CAIs are thought to have formed by gas-solid condensation (MacPherson and Grossman 1984), whereas CTA CAIs crystallized from melts (Simon et al. 1999). However, spinel and hibonite grains in FTA CAIs often have rounded or corroded outlines, and melilite grains often show inverse compositional zoning, probably reflecting incomplete melting and evaporation (Allen et al. 1978; Simon et al. 2001). As a result, there is a textural and mineralogical continuum between CTA and FTA CAIs. One of such intermediate FTA/CTA CAIs studied, $A L H-2$, is described below.

Fluffy/compact type A CAI $A L H-2$ (Fig. 1a, b) consists mostly of gehlenitic melilite $\left(\AA k_{1-24}\right)$, hibonite, spinel, perovskite, and traces of $\mathrm{Al}$,Ti-diopside (MacPherson and Grossman 1984; Simon et al. 2001). Melilite ranges from small, prismatic crystals $40-70 \mu \mathrm{m}$ across to anhedral grains $\sim 200 \mu \mathrm{m}$ across. The melilite grains show inverse chemical zoning with Åk-poor rims and relatively Åk-rich cores. The CAI is surrounded by a multilayered Wark-Lovering (WL) rim (from inside outward) of hibonite + spinel + perovskite, nearly pure gehlenite, and $\mathrm{Al}, \mathrm{Ti}$-diopside, a coarse-grained forsteritic olivine accretionary rim (Krot et al. 2001a), a fine-grained matrix-like rim, and a layer of $\mathrm{Ca}$,Fe-rich silicates (salitehedenbergite pyroxenes and andradite).

Compact type A CAIs, including those studied here (818-G, CG-13/15, TS-68, and TS-2) consist of melilite, spinel, Al,Ti-diopside (16-20 wt\% $\mathrm{TiO}_{2}, 18-21 \mathrm{wt} \%$ $\mathrm{Al}_{2} \mathrm{O}_{3}$ ), perovskite, \pm hibonite, and \pm platinum group element-bearing (PGE) metal nuggets. Melilite in most CTA CAIs is typically highly gehlenitic ( $\AA_{<33}$ ); åkermanite content increases towards the CAI cores. Individual melilite grains typically show normal igneous zoning. Nearly pure gehlenite ( $\mathrm{Ak}_{3}$ ) occurs in and near WL rims. The anomalous CTA CAI TS-2 (Fig. 1c-f), characterized in detail by Simon et al. (1998), shows a much larger compositional range of melilite $\left(\AA \mathrm{k}_{9-65}\right)$. Many melilite crystals consist of patches of åkermanitic melilite $\left(\AA k_{32-62}\right.$, median $\left.\AA \mathrm{k}_{52}\right)$ set in or partially enclosed by, and optically continuous with, relatively gehlenitic melilite $\left(\AA \mathrm{k}_{25-53}\right.$, median $\left.\AA \mathrm{k}_{38}\right)$. The gehlenitic melilites have dendritic shapes and enclose numerous, fine inclusions of spinel and minor perovskite and $\mathrm{Al}, \mathrm{Ti}$-diopside. Coarse-grained spinel, $\sim 50-150 \mu \mathrm{m}$ across, occurs in clumps and chains enclosed in relatively åkermanitic melilite. The sample also contains a spinel-free palisade body composed almost entirely of Åk-rich (45-65 mol\%) Na-bearing (up to 0.15 wt $\% \mathrm{Na}_{2} \mathrm{O}$ ) melilite. Melilite near WL rim is highly gehlenitic $\left(\AA k_{9}\right)$. 


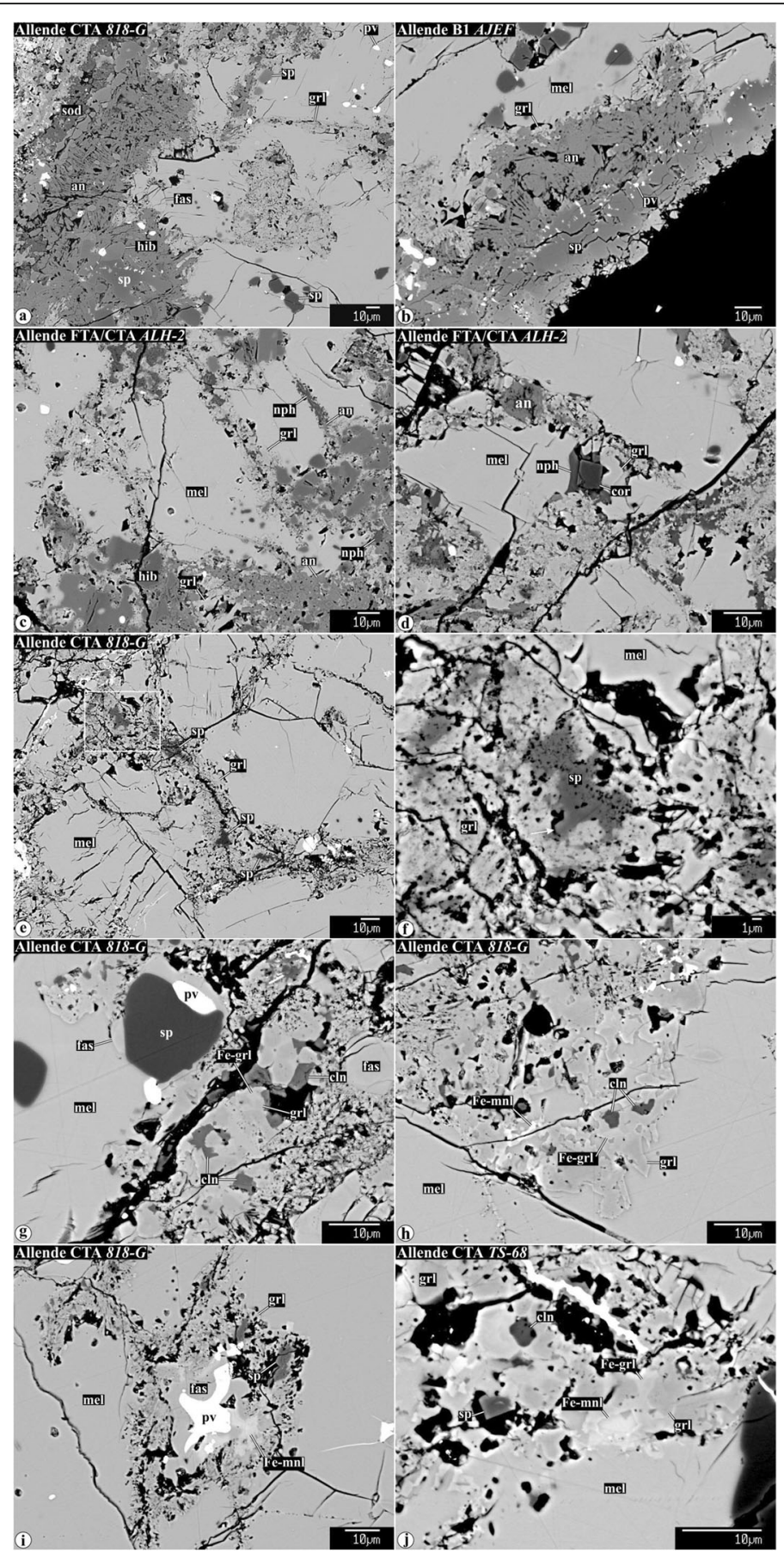

Fig. 3 Backscattered electron images of secondary minerals replacing gehlenitic melilite in CTA CAls and mantles of Type B1 CAls. In the CAI peripheries, melilite is replaced by anorthite and grossular. The abundance of anorthite decreases, whereas the abundance of grossular increases towards the CAl interiors. Other phases coexisting with grossular in the CAl interiors are micron-sized spinel, clintonite, FeO-enriched monticellite, and FeO-enriched grossular. The ferroan monticellite and grossular overgrow FeO-poor grossular. Clintonite is typically enclosed by grossular. Spinel grains growing into void space in veins have euhedral outlines (indicated by arrow in $\mathbf{f}$ ). Near the CAl edges, secondary anorthite is replaced by nepheline, sodalite, and ferromagnesian olivine

\subsubsection{Type B CAls}

Type B CAIs consist of melilite, Al,Ti-diopside, spinel, anorthite, and minor perovskite, hibonite, and \pm PGE metal nuggets. A small subset of Type B inclusions contain igneous forsterite; these are classified as forsterite-bearing Type B CAIs (FoB, Bullock et al. 2012). Type Bs are subdivided into two textural subtypes: the B1s, which have a melilite-rich outer mantle 


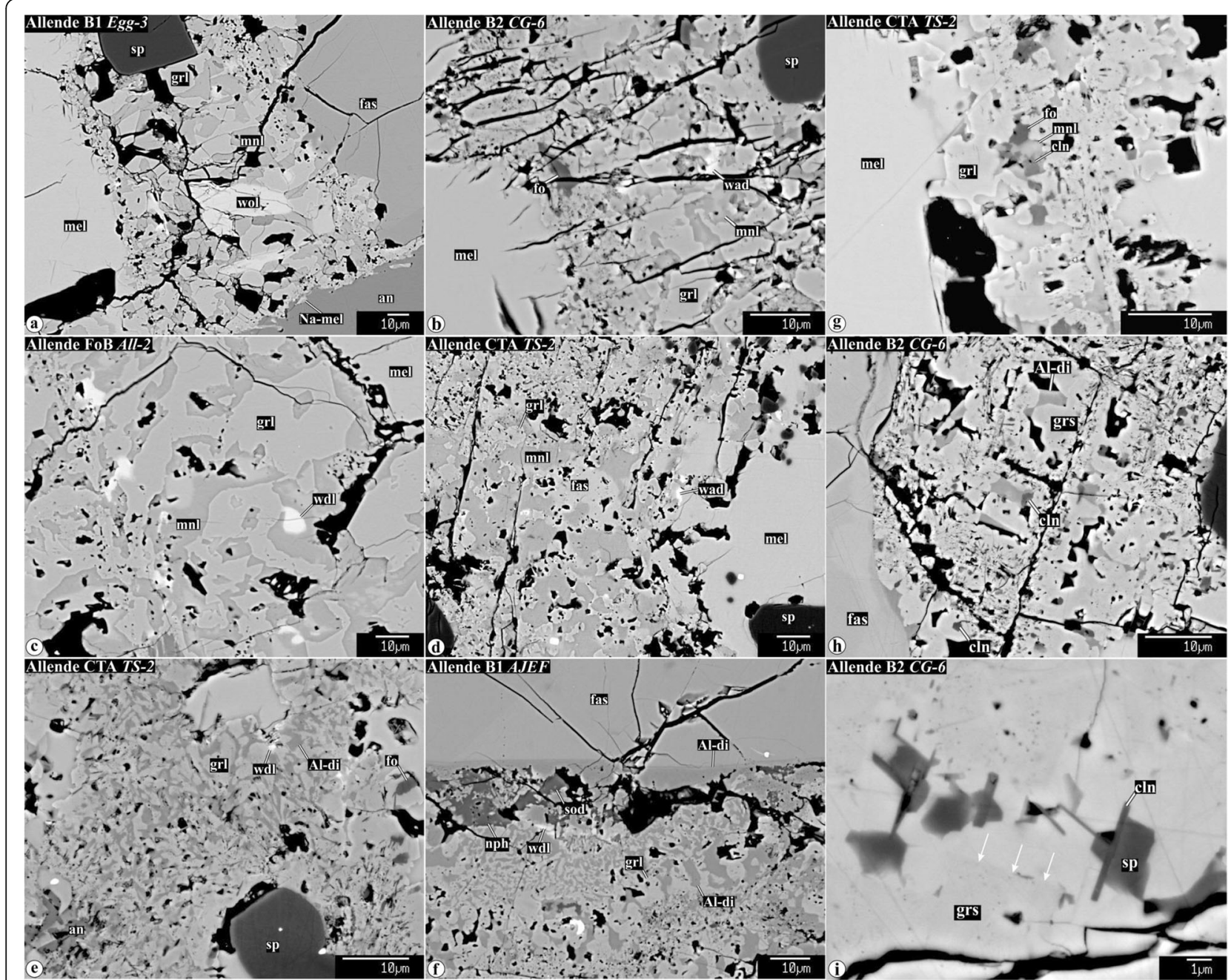

Fig. 4 Backscattered electron images of secondary mineral assemblages replacing åkermanitic melilite in Type B1, B2, FoB, and CTA CAls: a grossular-monticellite-wollastonite, $\mathbf{b}$ - $\mathbf{d}$ grossular-monticellite, and $\mathbf{e}, \mathbf{f}$ grossular-Al-diopside. All these mineral assemblages may contain minor clintonite, forsterite, spinel, Na-melilite, and wadalite. Na-melilite is commonly observed at the boundary between altered melilite and igneous anorthite (see a). Arrows in i indicate a boundary between grossulars with different $\mathrm{MgO}$ contents (dark, 3.7 and light, 2.3 wt\%)

enclosing a pyroxene-rich core; and the B2s, which have a rather homogeneous distribution of minerals (Wark and Lovering 1982b; Simon and Grossman 2006). There is a textural continuum between B1s and B2s. Melilite compositions of Type B1 and B2 inclusions are generally similar $\left(\AA \mathrm{k}_{5-75}\right)$. The composition of melilite in FoBs spans even a larger range $\left(\AA_{k_{6-90}}\right)$. There is a positive correlation between $\AA \mathrm{k}$ and $\mathrm{Na}_{2} \mathrm{O}$ contents in Type Bs. Melilite in the outermost parts of type B1 mantles is generally more gehlenitic than that in B2s, FoBs, and cores of type B1s. Both normally and inversely zoned regions are observed within individual melilite grains in type Bs (MacPherson et al. 1984; Simon and Grossman 2006). Fassaite grains are igneously zoned with decreasing $\mathrm{TiO}_{2}, \mathrm{Sc}_{2} \mathrm{O}_{3}$, and $\mathrm{V}_{2} \mathrm{O}_{3}$ contents from cores to edges of the grains. Anorthite and spinel are compositionally pure.
Type B1 CAI TS-23 (Fig. 1g-j) consists of melilite, Al,Ti-diopside (3-8 wt\% $\quad \mathrm{TiO}_{2} ; 15-20$ wt\% $\quad \mathrm{Al}_{2} \mathrm{O}_{3}$ ), spinel, and anorthite (Grossman 1975; Hutcheon et al. 1978; MacPherson et al. 1984; Simon and Grossman 2006). It has a gehlenitic melilite mantle $\sim 0.5-1 \mathrm{~mm}$ thick that encloses sparse spinel and fassaite grains and surrounds a relatively fassaite-rich and melilite-poor core. Melilite crystals $\left(\AA \mathrm{k}_{27-72}\right)$ in the core show complex (normal and reverse) compositional zoning (MacPherson et al. 1984). The CAI is surrounded by a spinel-Al-diopside WL rim, a fine-grained matrix-like rim composed of ferroan olivine and nepheline, and a layer of Ca,Fe-rich silicates composed of salite-hedenbergite pyroxenes, andradite, and wollastonite.

The anomalous Type B2 CAI TS-31 (Fig. 1k, l) consists of highly åkermanitic melilite ( $\mathrm{A}_{76-87} ; 0.1-0.2 \mathrm{wt} \%$ $\left.\mathrm{Na}_{2} \mathrm{O}\right)$, sector-zoned Al,Ti-diopsides $\left(\mathrm{TiO}_{2}, 4-11 \mathrm{wt} \%\right.$; 


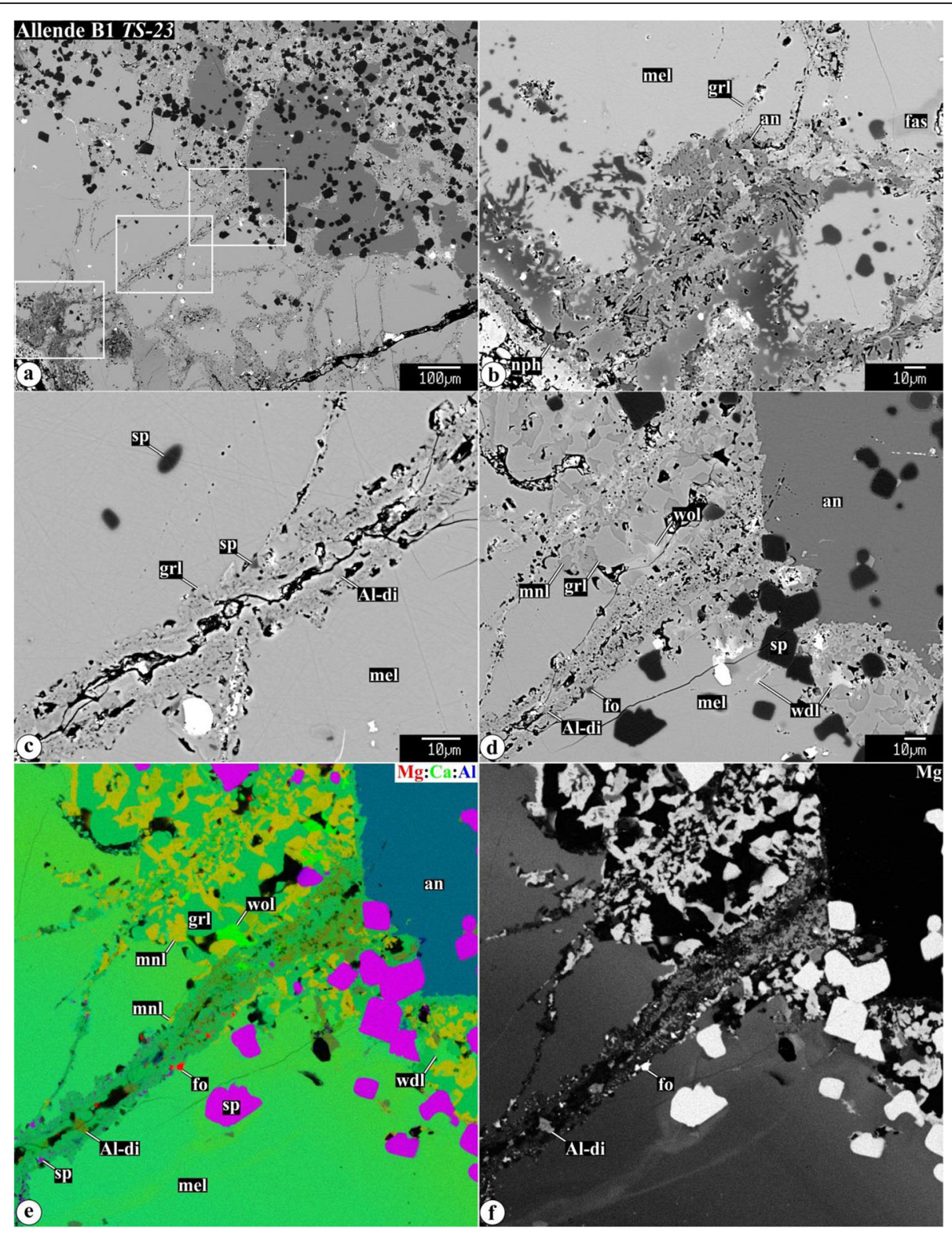

Fig. 5 a-d Backscattered electron images, e combined x-ray elemental map in Mg (red), Ca (green), and Al (blue), and $\mathbf{f}$ elemental map in Mg of a vein crosscutting gehlenitic melilite mantle around Type B1 CAI TS-23. Regions outlined in $\mathbf{a}$ are shown in detail in $\mathbf{b}$, $\mathbf{c}$, and $\mathbf{d}-\mathbf{f}$, respectively. Towards the CAI interior, the melilite becomes more åkermanitic. The mineralogy of the vein changes towards the CAI interior from anorthite-rich to grossular-rich; minor phases include Al-diopside, forstetrite, and spinel. Åkermanitic melilite in the core is replaced by coarse-grained grossular, monticellite, wollastonite, and minor wadalite

$\left.\mathrm{Al}_{2} \mathrm{O}_{3}, 12-22 \mathrm{wt} \%\right)$, and compositionally pure anorthite and spinel. The peripheral portion of the CAI is extensively altered and contains small anhedral Ti-rich fassaites $\left(\mathrm{TiO}_{2}, 17-20 \mathrm{wt} \% ; \mathrm{Al}_{2} \mathrm{O}_{3}, 18-20 \mathrm{wt} \%\right)$. WarkLovering rim layers cannot be clearly defined due to extensive alteration. The CAI is surrounded by a finegrained matrix-like rim composed of lath-shaped ferroan olivine and nepheline grains, and by a discontinuous layer of salite-hedenbergite pyroxenes + andradite + wollastonite.
Forsterite-bearing Type B CAI Al-2 (Fig. 1m, n) consists mainly of Al,Ti-diopside $\left(\mathrm{TiO}_{2}, 0.6-5.5 \mathrm{wt} \% ; \mathrm{Al}_{2} \mathrm{O}_{3}\right.$, 4.7-21.7 wt\%), highly åkermanitic Na-bearing melilite ( $\AA \mathrm{k}_{79-87}, 0.12-0.23 \mathrm{wt} \% \mathrm{Na}_{2} \mathrm{O}$ ), and compositionally pure anorthite; all phases poikilitically enclose Ca-rich (1.0$1.3 \mathrm{wt} \% \mathrm{CaO}$ ) forsterite and spinel grains. Distribution of forsterite is very heterogeneous. Anorthite is preferentially concentrated in the peripheral part of the inclusion. The CAI is surrounded by a spinel-rich layer containing rare grains of hibonite $\left(\mathrm{TiO}_{2}, 0.97 \mathrm{wt} \%\right.$; 


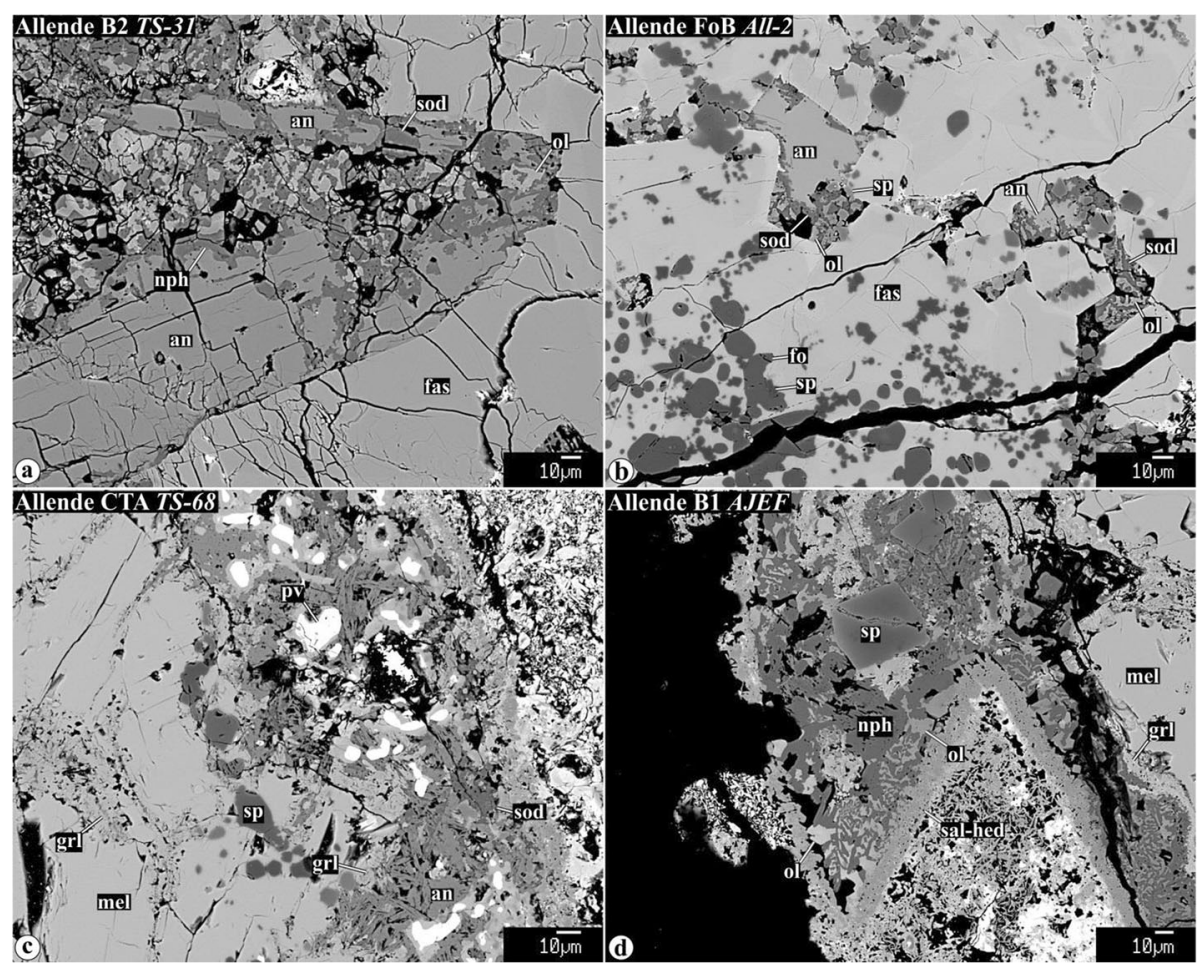

Fig. 6 Backscattered electron images primary anorthite $(\mathbf{a}, \mathbf{b})$ and secondary anorthite $(\mathbf{c}, \mathbf{d})$ in the peripheries of the Allende coarse-grained igneous CAls. Both types of anorthite are replaced by nepheline, sodalite, and ferromagnesian olivine

$\mathrm{MgO}, 8.5 \mathrm{wt} \%)$, a fine-grained matrix-like rim composed of lath-shaped ferroan olivine and nepheline, and a layer of salite-hedenbergite pyroxenes + andradite + wollastonite.

\subsubsection{Type C CAls}

Type C CAI 160 is a fragmented inclusion partly surrounded by a WL rim of spinel and Al,Ti-diopside (Fig. 1o, p; see also Figs. 10 and 11 in Krot et al., 2007b). It is composed of $\mathrm{Al}, \mathrm{Ti}$-diopside, melilite, and spinel, all embedded into a fine-grained anorthite groundmass. Anorthite is compositionally pure $\mathrm{CaAl}_{2} \mathrm{Si}_{2} \mathrm{O}_{8}$. Al,Ti-diopside $\left(\mathrm{TiO}_{2}, 4.6-13.9 \mathrm{w} \% \mathrm{Al}_{2} \mathrm{O}_{3}, 18-20 \mathrm{wt} \%\right)$ occurs as coarse grains with abundant 3-5 $\mu \mathrm{m}$-sized inclusions of anorthite (lacy pyroxenes; Wark 1987) and rounded inclusions of spinel, and as rare massive grains poikilitically enclosing euhedral spinel (see Fig. 11 in Krot et al., 2007b). Melilite occurs as coarse subhedral grains with abundant 3-5 $\mu \mathrm{m}$-sized inclusions of anorthite (named "lacy melilite" by Wark 1987) and as compact polycrystalline regions with interstitial Al,Ti-diopside and poikilitically enclosing spinel. Melilite in the CAI mantle is more gehlenitic than in its core $\left(\AA_{k_{44-56}}\right.$ vs. $\left.\AA k_{56-72}\right)$; in both occurrences, melilite contains detectable $\mathrm{Na}_{2} \mathrm{O}$ (0.10-0.36 wt\%) (Fig. 3 in Krot et al., 2007b). Spinel, nearly pure $\mathrm{MgAl}_{2} \mathrm{O}_{4}$, is heterogeneously distributed within the CAI and occurs as individual grains enclosed in melilite, anorthite and $\mathrm{Al}, \mathrm{Ti}$-diopside, and as framboids.
4.2 Alteration of primary and secondary minerals in the Allende CAls

\subsubsection{Alteration of gehlenitic melilite in compact type $A$ CAls and type $B 1 \mathrm{CAls}$}

Gehlenitic melilite is common in CTAs and mantles of Type B1s. Nearly pure gehlenite occurs near WL in most CAIs studied. Highly gehlenitic melilite $\left(\AA^{2} k_{<10}\right)$ in the outermost regions of all CAIs studied is replaced by nearly monomineralic anorthite/dmisteinbergite (Fig. 3a-c; hereafter anorthite; Raman or EBSD studies are required to distinguish between anorthite and dmisteinbergite; Fintor et al. 2014; Park et al. 2013). The anorthite/grossular ratio decreases towards the CAI cores (Fig. 3a-c), which correlates with the increase of akkermanite content in melilite $\left(\AA k_{5-20}\right)$. Minor clintonite, spinel, and corundum occur in grossular-rich veins (Fig. 3d-g). Secondary spinel and corundum grains are generally less than $3 \mu \mathrm{m}$ in size, and often form subhedral-to-euhedral grains (Fig. 3d-f, i, j). Occasionally, large concentrations of $\mu \mathrm{m}$-sized spinel grains occupy central zones of some grossular-rich veins (Fig. 3e,f). Subhedral-to-anhedral clintonite grains generally occur in interstitial regions between grossular grains (Fig. 3g). In the clintonite-bearing regions, the compositionally distinct grossular grains are observed-FeOpoor/free and FeO-bearing; the latter typically overgrow the former and may associate with ferroan monticellite (monticellite-kirschsteinite solid solution) (Fig. 3g-j). 


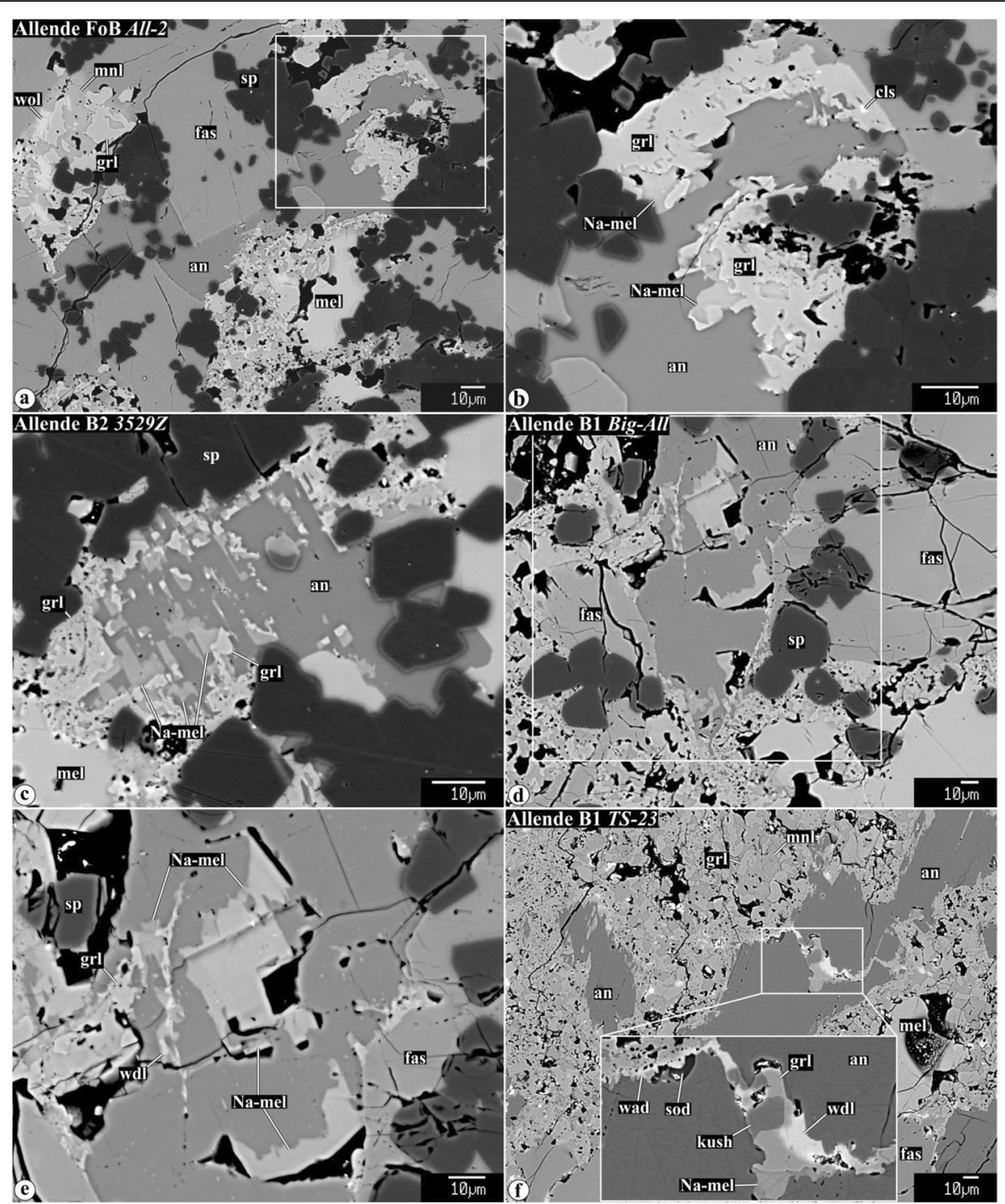

Fig. 7 Backscattered electron images of Alteration of primary igneous anorthite in the interior regions of the Type B1, B2, and FoB Allende CAls. Regions outlined in $\mathbf{a}$ and $\mathbf{e}$ are shown in details in $\mathbf{b}$ and $\mathbf{f}$. Anorthite along the boundaries with heavily altered regions of åkermanitic melilite contains irregularly shaped embayments, inclusions along cleavage planes, and veins of Na-melilite, grossular, kushiroite, and wadalite.

Occasionally, wadalite is replaced by sodalite. Na-melilite growing into open space shows euhedral outlines (see $\mathbf{e}$ and $\mathbf{f}$ ). Variations in brightness of $\mathrm{Na}$-melilite correspond to variations in $\mathrm{Na}_{2} \mathrm{O}$ content

\subsubsection{Alteration of åkermanitic melilite}

Åkermanitic melilite is common in B2s, FoBs, Cs, cores of B1s, and CTA CAI TS-2. Several assemblages of secondary minerals replacing åkermanitic melilite are observed in the CAIs studied: (i) grossular + monticellite + wollastonite (Fig. 4a), (ii) grossular + monticellite (Fig. 4b-d), and (iii) grossular + Al-diopside (Fig. 4de, f). Minor wadalite (Fig. 4a-f), forsterite (Fig. 4b, g), clintonite (Fig. 4g-i), and spinel (Fig. 4i) can be found in all of them. In the clintonite-bearing regions, two compositionally distinct grossulars are observed with sharp boundaries between them-FeO-poor/free and FeO- bearing (Fig. 4i). In contrast to secondary minerals replacing gehlenitic melilite, secondary anorthite replacing åkermanitic melilite is virtually absent.

Changes in secondary mineral assemblages replacing melilite of different chemical compositions are illustrated in Fig. 5 showing a vein crosscutting a gehlenitic melilite mantle around Type B1 CAI TS-23. Near the WL rim, the vein consists predominantly of anorthite. Towards the CAI core, the abundance of anorthite decreases, whereas the abundance of grossular increases. In the anorthite-free regions of the grossular vein, minor $\mathrm{Al}$ diopside, monticellite, and forsterite are observed. The 

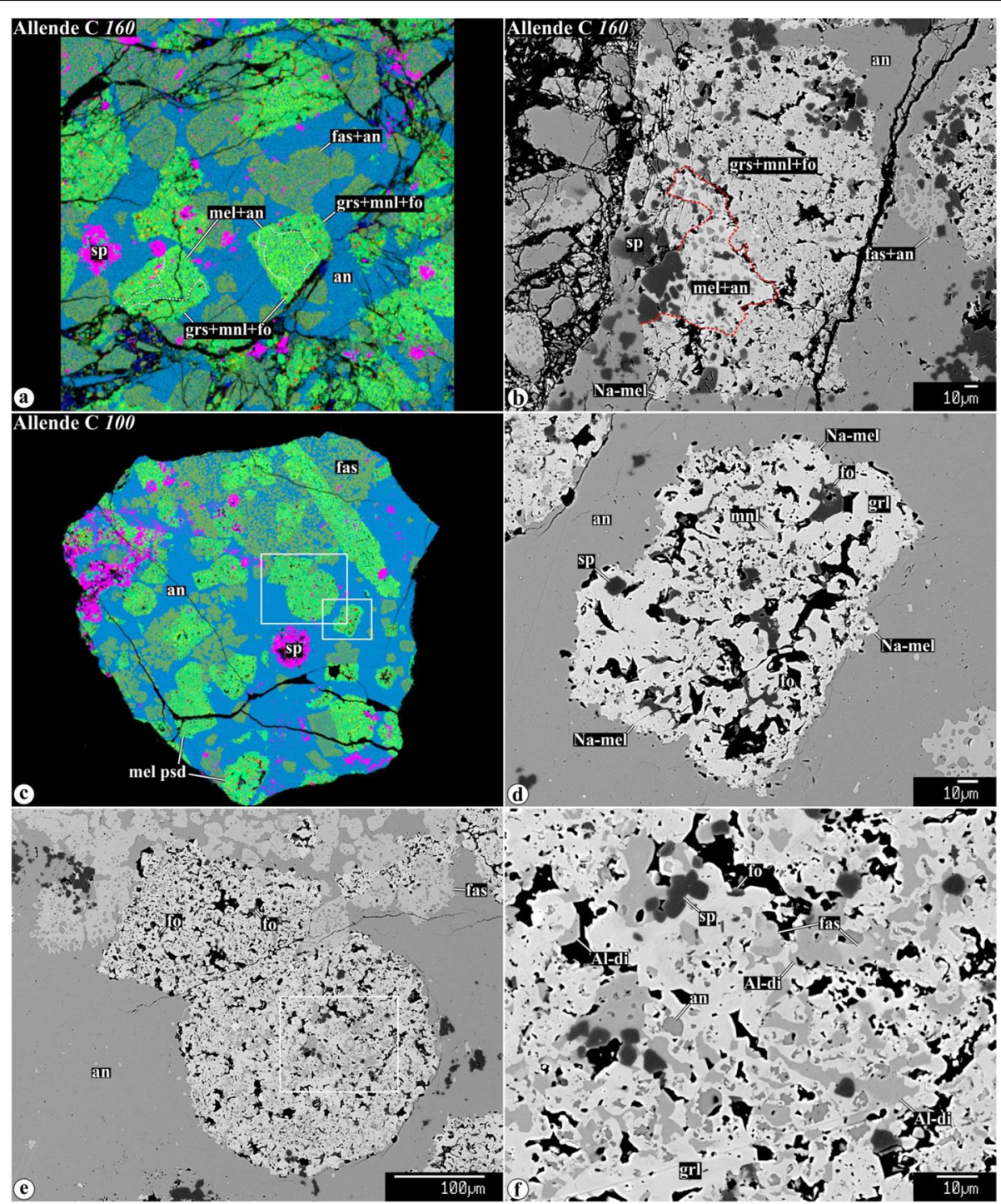

Fig. 8 a, c Combined x-ray elemental maps in Mg (red), Ca (green), and Al (blue), and (b, $\mathbf{d}-\mathbf{f}$ ) backscattered electron images of the interior regions of Type C CAls $(\mathbf{a}, \mathbf{b}) 160$ and $(\mathbf{c}-\mathbf{f})$ 100. Regions outlined in $\mathbf{c}$ and $\mathbf{e}$ are shown in detail in $\mathbf{d}-\mathbf{f}$, respectively. Lacy melilite composed of åkermanitic melilite with numerous rounded inclusions of anorthite is pseudomorphically replaced to various degrees by grossular-forsteritemonticellite and grossular-Al-diopside. Anorthite groundmass around melilite pseudomorphs shows little evidence for alteration: small amount of Na-melilite occurs along edges of melilite pseudormorphs

abundance of Al-diopside is highest in a region where the vein enters the CAI core containing åkermanitic melilite (Fig. 5e). The åkermanitic melilite in the core is replaced by a coarse-grained mineral assemblage of grossular, monticellite, wollastonite, and wadalite (Fig. 5d).

\subsubsection{Alteration of primary and secondary anorthite}

Both primary and secondary anorthites in the peripheral portions of CAIs are replaced by nepheline, sodalite, and minor ferromagnesian olivine (Figs. 1 and 6). There are no clear textural relationships between nepheline and sodalite. Sodalite tends to be located closer to the CAI interiors than nepheline (Fig. 1d, l); however, this is not always the case (Fig. 1b, n). Ferromagnesian olivine ranges in composition from $\mathrm{Fa} \sim 10$ to $\mathrm{Fa} \sim 40$; fayalite content typically increases towards CAI peripheries.

In contrast to åkermanitic melilite, coarse-grained primary anorthite in type B and FoB CAI cores is generally only weakly altered. In contact with altered regions of åkermanitic melilite, the edges of anorthite grains appear to be corroded by Na-rich melilite and nearly pure grossular (Fig. 7a, b). In some cases, Na-rich melilite and grossular occur along cleavage planes of the anorthite grains (Fig. 7c). In others, subhedral grains of $\mathrm{Na}$ melilite grow in open spaces within anorthite crystals (Fig. 7d, e). These subhedral grains of Na-melilite are 

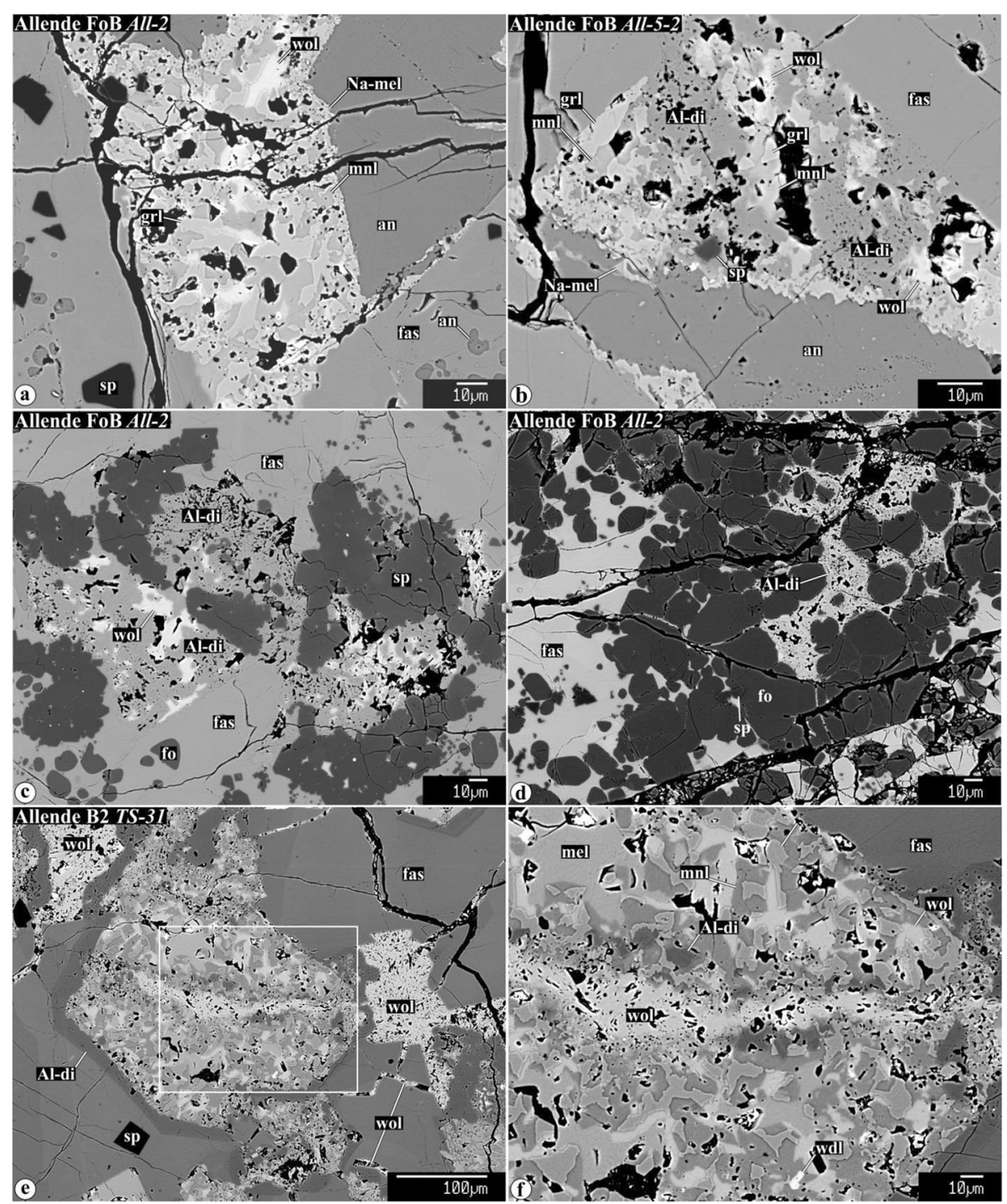

Fig. 9 Backscattered electron images of multiple generation of secondary mineral assemblages in the Allende Type B CAls. Region outlined in $\mathbf{e}$ is shown in detail in $\mathbf{f}$. a-d Replacement of grossular-monticellite-wollastonite assemblages to various degrees by Al-diopside. e, $\mathbf{f}$ Grossularmonticellite-wollastonite-Al-diopside assemblage is crosscut by a wollastonite vein. Wollastonite also fills veins and irregularly shaped regions in fassaite

often chemically zoned: sodium content increases towards grain edges. Occasionally, anorthite grains are crosscut by veins composed of Na-melilite, grossular, \pm kushiroite, and \pm wadalite (Fig. 7e, f).

\subsubsection{Alteration of lacy melilite in Type C CAls}

In type C CAIs 160 and 100, melilite and fassaite grains have "lacy" textures characterized by the presence of abundant rounded inclusions of anorthite $\sim 5-10 \mu \mathrm{m}$ in size. The lacy melilite and fasssaite are embedded in fine-grained $(\sim 5 \mu \mathrm{m}$ in size $)$ anorthite groundmass (Figs. 1 and 8o). Anorthite inclusions in lacy fassaite and melilite, and anorthite groundmass in the CAI cores show little evidence for alteration. At the same time, lacy melilite grains are pseudomorphed to varying degrees by grossular + forsterite + monticellite (Fig. 8a-d) and grossular + Al-diopside assemblages (Fig. $d-f$ ). Although the outlines of the original lacy melilite grains are generally well-preserved, the replaced portions are highly porous. The secondary grossular, forsterite, and Al-diopside growing into the pore spaces often show euhedral outlines (Fig. 8d, f). X-ray elemental mapping revealed enrichment in sodium along the peripheries of the pseudomorphed lacy melilites (see Fig. 2EA in Krot et al., 2007b). This enrichment is due to the presence of micron-sized anhedral grains of Na-rich melilite (Fig. 8b, d). 


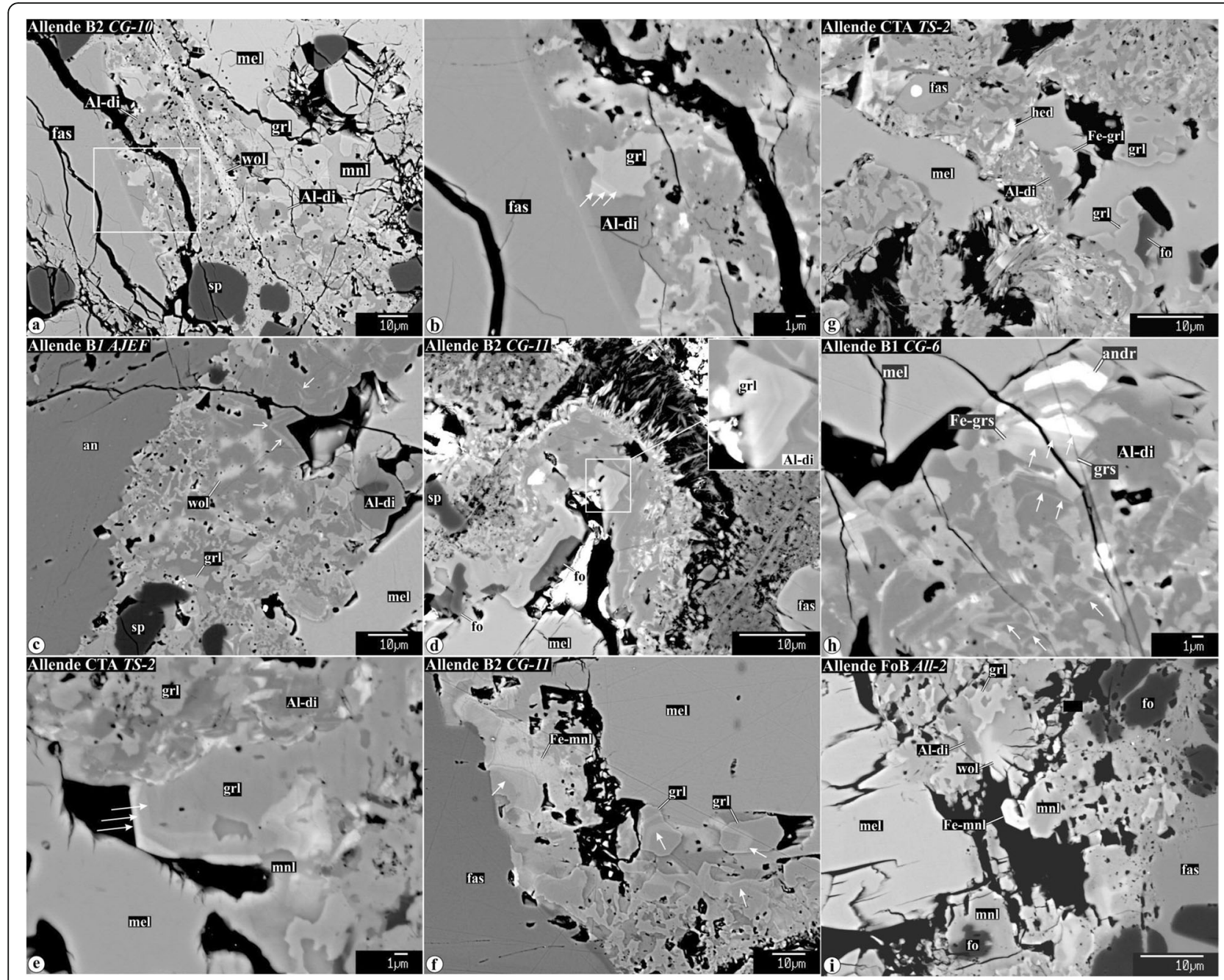

Fig. 10 Backscattered electron images of chemically zoned secondary minerals in the Allende coarse-grained CAls. The oscillatory zoned grossular and Al-diopside are commonly observed in grossular-Al-diopside mineral assemblages and often contain FeO-rich secondary minerals: andradite, hedenbergite, ferroan monticellite, and ferroan grossular

\subsubsection{Secondary minerals replacing, overgrowing, and crosscutting earlier formed secondary phases}

Some secondary minerals and/or mineral assemblages can be replaced, overgrown, and crosscut by newly formed ones, as illustrated in Figs. 9, 10, and 11. For example, $(i)$ grossular + monticellite + wollastonite mineral assemblages replacing highly åkermanitic melilite in the FoB CAIs All-2 and All-5-2 are in turn replaced to a various degree by Al-diopside (Fig. 9a-d). (ii) In the Type B2 CAI TS-31, grossular + monticellite + wollastonite mineral assemblages replacing åkermanitic melilite are crosscut by wollastonite veins (Fig. 9e, f). (iii) In the Type B2 CAI CG-10, a wollastonite vein crosscuts an $\mathrm{Al}$-diopside-rich region replacing an earlier formed grossular + monticellite_wollastonite assemblage (Fig. 10a); grossular in the Al-diopside-rich region shows oscillatory zoning (Fig. 10b). The coexisting oscillatory zoned grossular and Al-diopside are also found in the CAIs AJEF (B1, Fig. 10c), CG-11 (B2, Fig. 10d, f), TS-2 (CTA, Fig. 10e), and CG-6 (B1, Fig. 10h). (iv) Occasionally, the earlier formed FeO-poor secondary minerals (Al-diopside, grossular, and monticellite) are either overgrown or crosscut by veins composed of ferroan grossular, ferroan monticellite, ferroan Al-diopside, hedenbergite, wollastonite, andradite, pentlandite, and heazlewoodite (Figs. 10 and $11 \mathrm{~g}-\mathrm{i}$ ).

\subsubsection{Secondary minerals in voids inside CAls}

Some coarse-grained igneous CAIs from Allende contain voids filled by anhedral-to-subhedral secondary grossular, monticellite, ferroan monticellite, wollastonite, tilleyite, calcite, andradite, hedenbergite, and Al-diopside (Fig. 12). 


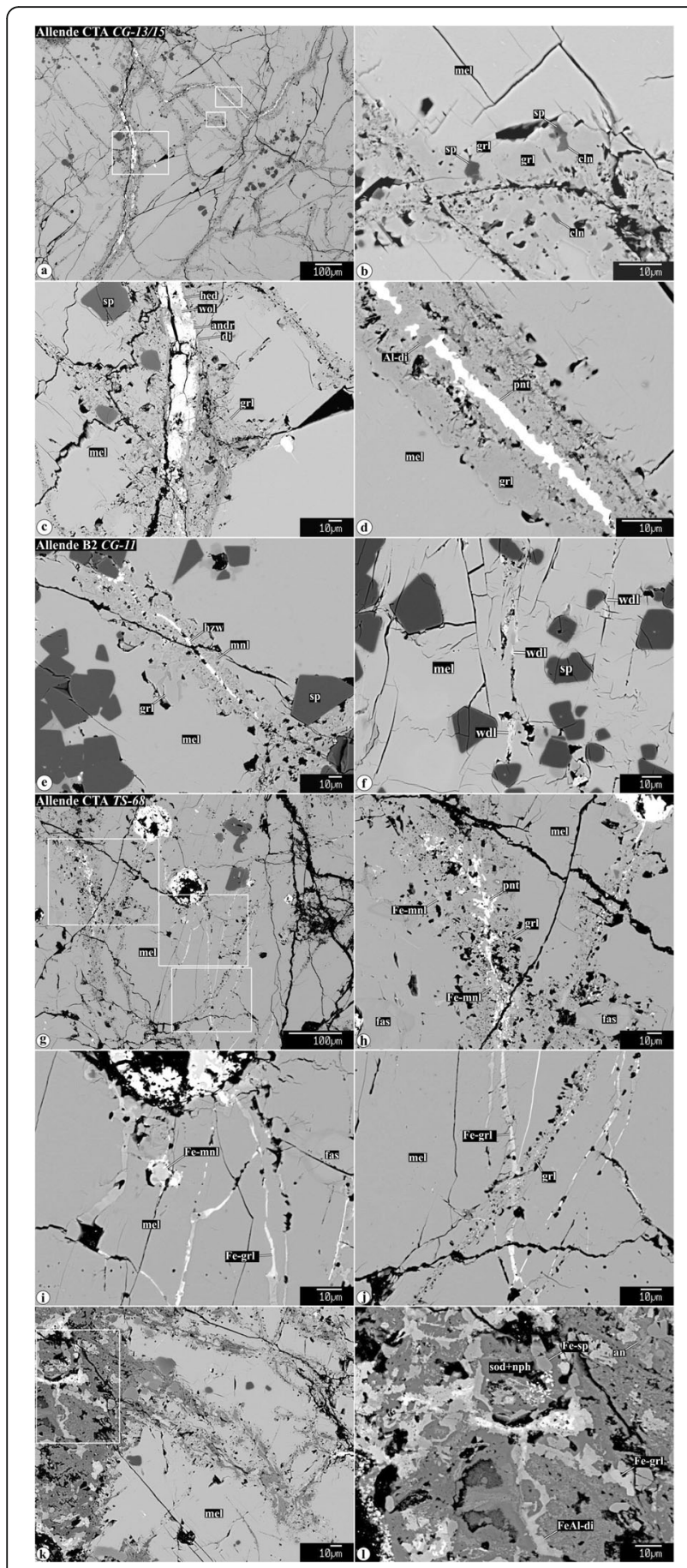

Fig. 11 Backscattered electron images of different generations of veins in the Allende coarse-grained CAls. Regions outlined in $\mathbf{a}$ and $\mathbf{g}$ are shown in detail in $\mathbf{b}-\mathbf{d}$ and $\mathbf{h}-\mathbf{j}$, respectively. Central regions of some grossular-rich veins are occupied by pentlandite, heazlewoodite, or andradite + wollastonite + hedenbergite. $\mathbf{g}-\mathbf{I}$ Occasionally, grossular-rich veins are crosscut by veins composed of ferroan grossular and ferroan-Al-diopside

\subsubsection{Secondary minerals around CAls}

All Allende CAIs studied are surrounded by the multilayered WL rims, fine-grained matrix-like rims, and a layer of $\mathrm{Ca}$,Fe-rich silicates (Fig. 1). The peripheral regions of the CAIs contain abundant nepheline and sodalite (green and yellow grains, respectively, in $\mathrm{Cl}: \mathrm{Na}: \mathrm{Al}$ combined elemental maps) replacing primary and secondary anorthite. Sodalite tends to occur closer to the CAI interiors than nepheline. Sodium-free Cl-rich minerals, wadalite and/or adrianite (red grains in $\mathrm{Cl}: \mathrm{Na}: \mathrm{Al}$ maps; EBSD studies are required to distinguish between these minerals) occur almost exclusively in CAIs containing åkermanite-rich melilite-B2s, FoBs, cores of B1s, and the anomalous CTA CAI TS-2.

The fine-grained matrix-like rims consist of lathshaped ferroan olivine, Fe,Ni-sulfides, and abundant nepheline grains typically enclosing lath-shaped ferroan olivine (Fig. 2). Occasionally, fine-grained rims contain salite-hedenbergite pyroxene nodules (Fig. 2b).

The calcium- and iron-rich silicate layers separate the fine-grained rims from the Allende matrix and consist of salite-hedenbergite pyroxenes, wollastonite, and andradite (Fig. 2c).

\subsection{Oxygen isotopic compositions}

In Fig. 13a-d, we plotted oxygen isotopic compositions of primary and secondary minerals in the coarse-grained Allende CAIs measured with the matrix-matched mineral standards. In Fig. 13g, h, we plotted the previously reported data for secondary andradite, grossular, magnetite, salite-hedenbergite pyroxenes, sodalite, and wollastonite measured without matrix-matched standards (magnetite is the only exception) in the Allende matrix, chondrules, and dark inclusions. Like in the previously reported dataset, most secondary minerals in the Allende CAIs plot along mass-dependent fractionation line with $\Delta^{17} \mathrm{O}$ of $\sim-3 \pm 2 \%$, but show a significantly smaller range of $\delta^{18} \mathrm{O}(\sim 0$ to $+10 \%$ vs. $\sim-15$ to $\sim+20 \%$ o $)$. Larger ranges of $\Delta^{17} \mathrm{O}$ were found in grossular and forsterite in the Type B1 CAI TS-34 $(\sim-10$ to $\sim-1 \%$ ) and Type C CAIs 100 and $160(\sim-15$ to $\sim-1 \%)$; these minerals plot along the CCAM line. The similar ranges of $\Delta^{17} \mathrm{O}$ are observed for primary anorthite in these CAIs; melilite is generally more ${ }^{16} \mathrm{O}$-depleted $\left(\Delta^{17} \mathrm{O} \sim-5\right.$ to $\sim$ $-1 \%)$. Spinel and fassaite are ${ }^{16} \mathrm{O}$-rich $\left(\Delta^{17} \mathrm{O} \sim-25\right.$ to $\sim$ $-20 \%$ ); the only exception is very $\mathrm{Ti}$-rich pyroxenes in TS-34, which are ${ }^{16} \mathrm{O}$-depleted to various degrees.

\subsection{Aluminum-magnesium isotope systematics}

In Fig. 14, we plotted excess of radiogenic ${ }^{26} \mathrm{Mg}\left({ }^{26} \mathrm{Mg}^{*}\right)$ vs. ${ }^{27} \mathrm{Al} /{ }^{24} \mathrm{Mg}$ ratio in gehlenitic melilite in the mantle and åkermanitic melilite in the core of the Type B CAI TS-34, and of secondary grossular replacing the melilite in this and several other Allende Type B CAIs. All 


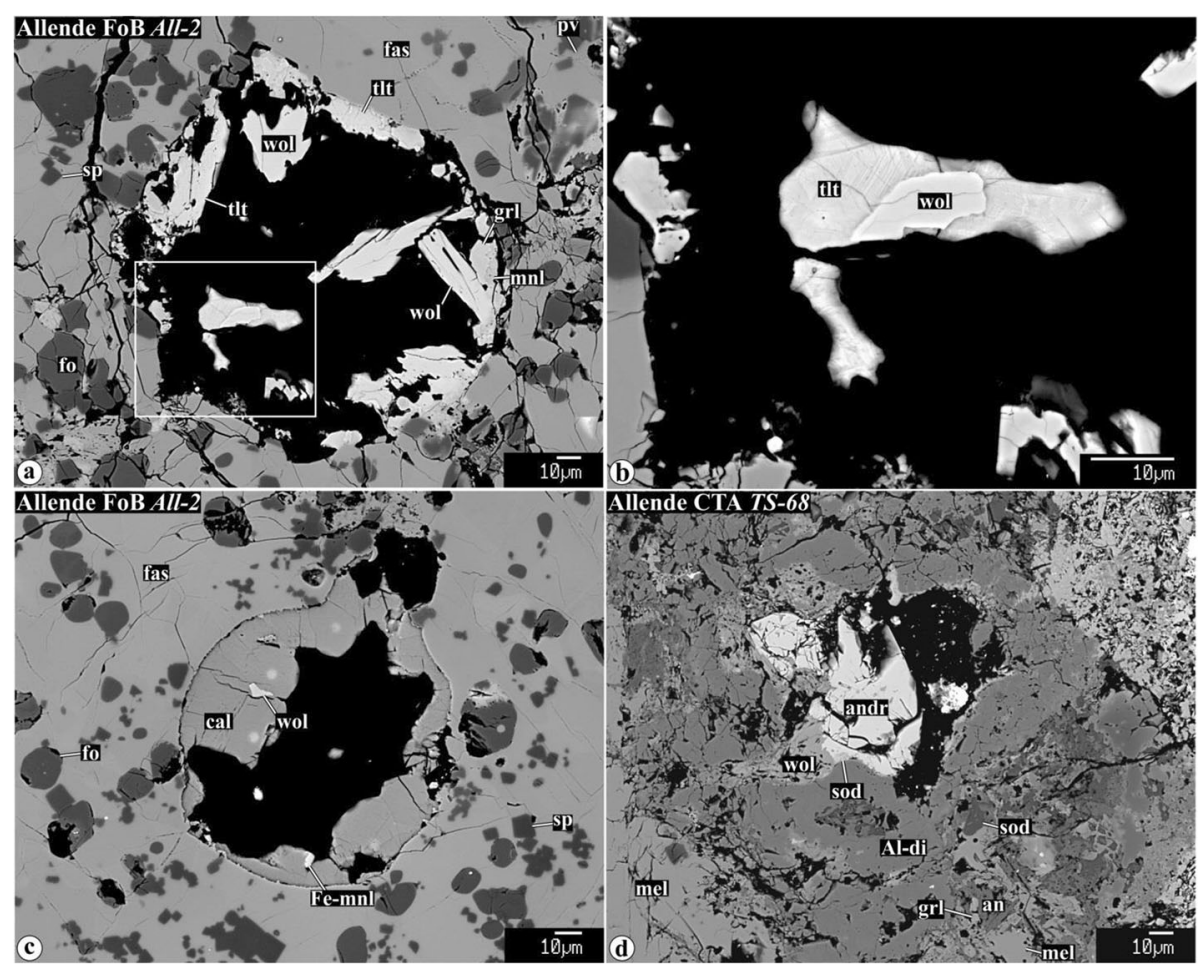

Fig. 12 Secondary minerals growing in voids inside coarse-grained Allende CAls. Region outlined in $\mathbf{a}$ is shown in detail in $\mathbf{b}$

melilite analyses in TS-34 show resolvable ${ }^{26} \mathrm{Mg}^{*}$ and plot along correlation line corresponding to the initial ${ }^{26} \mathrm{Al} /{ }^{27} \mathrm{Al}$ ratio of $(5.4 \pm 0.3) \times 10^{-5}$, which is indistinguishable from the canonical value of $(5.25 \pm 0.02) \times 10^{-5}$ (Larsen et al. 2011). Grossular grains in veins crosscutting the gehlenitic melilite mantle in TS-34 show resolvable ${ }^{26} \mathrm{Mg}^{*}$ and ${ }^{27} \mathrm{Al} /{ }^{24} \mathrm{Mg}$ ratio (in most cases, $\sim 7-10$ ) similar to those of melilite and plot along the Al-Mg isochron defined by the melilite. The coarse grossular grains replacing åkermanitic melilite and associating with monticellite, wollastonite, Al-diopside, and forsterite have significantly higher ${ }^{27} \mathrm{Al} /{ }^{24} \mathrm{Mg}$ ratios, $\sim 30-100$ (50-62 in TS-34), and show no resolvable ${ }^{26} \mathrm{Mg}^{*}$ within $2 \sigma$ uncertainty of our measurements, $\sim \pm 2 \%$.

\subsection{Secondary mineral assemblages in the Allende CAls and inferred metasomatic reactions \\ 4.5.1 Alteration of gehlenitic melilite}

Highly gehlenitic melilite $\left(\AA^{2} k_{<10}\right)$ in the outermost regions of the Allende CAIs is largely replaced and crosscut by veins of nearly monomineralic anorthite; grossular and corundum are minor. The abundance of anorthite in veins decreases and the abundance of grossular increases towards the CAI interiors containing more åkermanitic melilite $\left(\AA \mathrm{k}_{10-30}\right)$. Other secondary minerals observed in the grossular-rich veins include clintonite, spinel, and Al-diopside. The presence of clintonite provides clear evidence for the involvement of $\mathrm{H}_{2} \mathrm{O}$ in the alteration reactions, which can be expressed in mass-balanced form as the following:

$$
\mathrm{R} 4: \underset{\text { gehlenite }}{\mathrm{Ca}_{2} \mathrm{Al}_{2} \mathrm{SiO}_{7(\mathrm{~s})}}+\mathrm{SiO}_{2} \rightarrow \underset{\text { anorthite }}{\mathrm{CaAl}_{2} \mathrm{Si}_{2} \mathrm{O}_{8(\mathrm{~s})}}+\mathrm{CaO}
$$

$$
\mathrm{R} 5: \underset{\text { gehlenite }}{2 \mathrm{Ca}_{2} \mathrm{Al}_{2} \mathrm{SiO}_{7(\mathrm{~s})}}+\underset{\text { grossular }}{3 \mathrm{SiO}_{2}} \rightarrow \underset{\text { anorthite }}{\mathrm{Ca}_{3} \mathrm{Al}_{2} \mathrm{Si}_{3} \mathrm{O}_{12(\mathrm{~s})}}+\underset{\mathrm{CaAl}_{2} \mathrm{Si}_{2} \mathrm{O}_{8(\mathrm{~s})}}{\mathrm{Cu}}
$$

$$
\text { R6 : } 3 \mathrm{Ca}_{2} \mathrm{Al}_{2} \mathrm{SiO}_{7(\mathrm{~s})}+3 \mathrm{SiO}_{2} \rightarrow 2 \mathrm{Ca}_{3} \mathrm{Al}_{2} \mathrm{Si}_{3} \mathrm{O}_{12(\mathrm{~s})}+\mathrm{Al}_{2} \mathrm{O}_{3(\mathrm{~s})}
$$$$
\text { gehlenite grossular corundum }
$$

R7 : $2 \mathrm{Ca}_{2} \mathrm{Al}_{2} \mathrm{SiO}_{7}+\mathrm{Ca}_{2} \mathrm{MgSi}_{2} \mathrm{O}_{7(\mathrm{~s})}+2 \mathrm{SiO}_{2} \rightarrow$ gehlenite- $\dot{a}$ kermanite ss

$$
\underset{\text { grossular }}{\mathrm{Ca}_{3} \mathrm{Al}_{2} \mathrm{Si}_{3} \mathrm{O}_{12(\mathrm{~s})}}+\underset{\text { diopside-Ca-Tschermakite ss }}{\mathrm{CaMgSi}_{2} \mathrm{O}_{6}}+\underset{\mathrm{CaAl}_{2} \mathrm{SiO}_{6(\mathrm{~s})}}{\mathrm{CaO}^{2}}+\mathrm{CaO}
$$

$\mathrm{R} 8: 3 \mathrm{Ca}_{2} \mathrm{Al}_{2} \mathrm{SiO}_{7}+2 \mathrm{Ca}_{2} \mathrm{MgSi}_{2} \mathrm{O}_{7(\mathrm{~s})}+\mathrm{H}_{2} \mathrm{O} \rightarrow$ gehlenite- $a$ kermanite ss

$$
\underset{\text { grossular }}{\mathrm{Ca}_{3} \mathrm{Al}_{2} \mathrm{Si}_{3} \mathrm{O}_{12(\mathrm{~s})}}+\mathrm{CaMg}_{2} \mathrm{Al}_{4} \mathrm{SiO}_{10}(\mathrm{OH})_{2(\mathrm{~s})}+6 \mathrm{CaO}+3 \mathrm{SiO}_{2}
$$



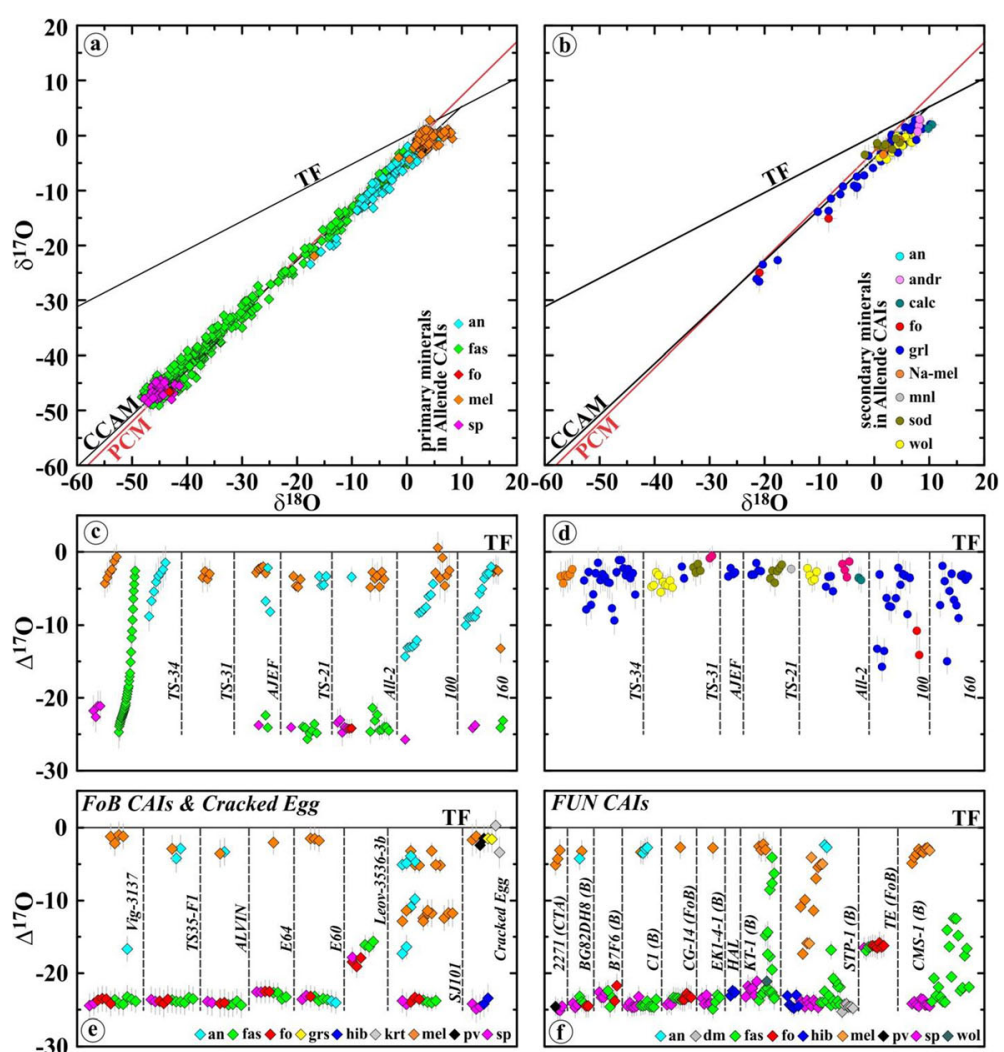

-30 e

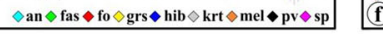
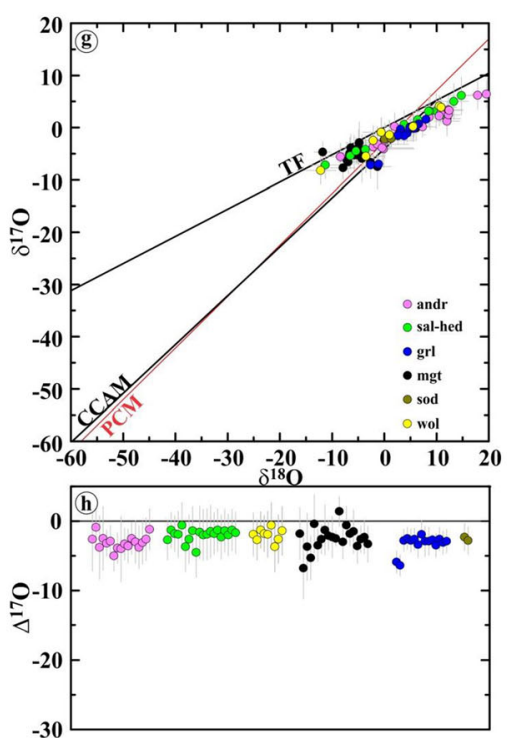

Fig. 13 (See legend on next page.) 
(See figure on previous page.)

Fig. 13 a, $\mathbf{b}$ Three-isotope oxygen diagrams and $\mathbf{c}, \mathbf{d} \Delta^{17} \mathrm{O}$ values of primary and secondary minerals in the Allende coarse-grained igneous $C A l s$ TS-34 (B1), TS-31 (B2), AJEF (B1), TS-21 (B2), All-2 (FoB), 100 (C), and 160 (C). Data for primary minerals in TS-34 are from Kawasaki et al. (2018). Spinel and most analyses of Al,Ti-diopside have ${ }^{16} \mathrm{O}$-rich compositions; anorthite and melilite are ${ }^{16} \mathrm{O}$-depleted to various degrees. Al,Ti-diopside grains in TS-34 show a large range of $\Delta^{17} \mathrm{O}$ that correlates with their igneous zoning: very Ti-rich pyroxene cores are ${ }^{16} \mathrm{O}$-depleted relative to Ti-poor pyroxene edges. Secondary minerals have generally ${ }^{16} \mathrm{O}$-poor compositions. The observed range of $\Delta^{17} \mathrm{O}$ of secondary minerals in individual CAls is similar to those of primary melilite and anorthite. $\mathbf{e}, \mathbf{f} \Delta^{17} \mathrm{O}$ values of primary minerals in coarse-grained igneous CAls of different types (CTA, $B$, $\mathrm{FoB}$, and Cracked Egg that is rich in krotite $\left(\mathrm{krt}_{1} \mathrm{CaAl}_{2} \mathrm{O}_{4}\right)$ and grossite ( $\left.\mathrm{grs}, \mathrm{CaAl}_{4} \mathrm{O}_{7}\right)$ ) from CV chondrites. FUN (fractionation and unidentified nuclear effects) CAls show large mass-dependent fractionation effects in oxygen isotopes indicating crystallization during melt evaporation in vacuum (Mendybaev et al. 2017). Melilite and anorthite in CV CAls of all types are ${ }^{16} \mathrm{O}$-depleted relative to hibonite, spinel, forsterite, and fassaite. The observed O-isotope heterogeneity may reflect mineralogically controlled exchange with an aqueous fluid $\left(\Delta^{17} \mathrm{O}=-3 \pm 2 \%\right.$ ) on the $\mathrm{CV}$ parent asteroid. Gas-melt isotopic exchange in gaseous reservoirs of variable oxygen isotopic composition cannot be excluded. Data from Bullock et al. (2012), Connolly et al. (2019c), Krot et al. (2014), and Williams et al. (2017). g Three-isotope oxygen diagram and $\mathbf{h} \Delta^{17} \mathrm{O}$ of secondary minerals in CAls, chondrules, and matrices of the oxidized Allende-like CV chondrites. Most secondary minerals were measured without matrix-matched standards; magnetite is the only exception. Data from Choi et al. (1997), Krot et al. (2000, 2010), and Cosarinsky et al. (2008)

$\mathrm{R} 9: 3 \mathrm{Ca}_{2} \mathrm{Al}_{2} \mathrm{SiO}_{7}+\mathrm{Ca}_{2} \mathrm{MgSi}_{2} \mathrm{O}_{7(\mathrm{~s})}+\mathrm{SiO}_{2} \rightarrow$

gehlenite-ákermanite ss

$$
\underset{\text { grossular }}{2 \mathrm{Ca}_{3} \mathrm{Al}_{2} \mathrm{Si}_{3} \mathrm{O}_{12(\mathrm{~s})}}+\underset{\text { spinel }}{\mathrm{MgAl}_{2} \mathrm{O}_{4(\mathrm{~s})}}+2 \mathrm{CaO}
$$

$\mathrm{R} 10: 2 \mathrm{Ca}_{2} \mathrm{Al}_{2} \mathrm{SiO}_{7}+\mathrm{Ca}_{2} \mathrm{MgSi}_{2} \mathrm{O}_{7(\mathrm{~s})}+2 \mathrm{SiO}_{2}+\mathrm{Al}_{2} \mathrm{O}_{3} \rightarrow$ gehlenite-äkermanite ss

$$
\underset{\text { grossular }}{2 \mathrm{Ca}_{3} \mathrm{Al}_{2} \mathrm{Si}_{3} \mathrm{O}_{12(\mathrm{~s})}}+\underset{\text { spinel }}{\mathrm{MgAl}_{2} \mathrm{O}_{4(\mathrm{~s})}}
$$

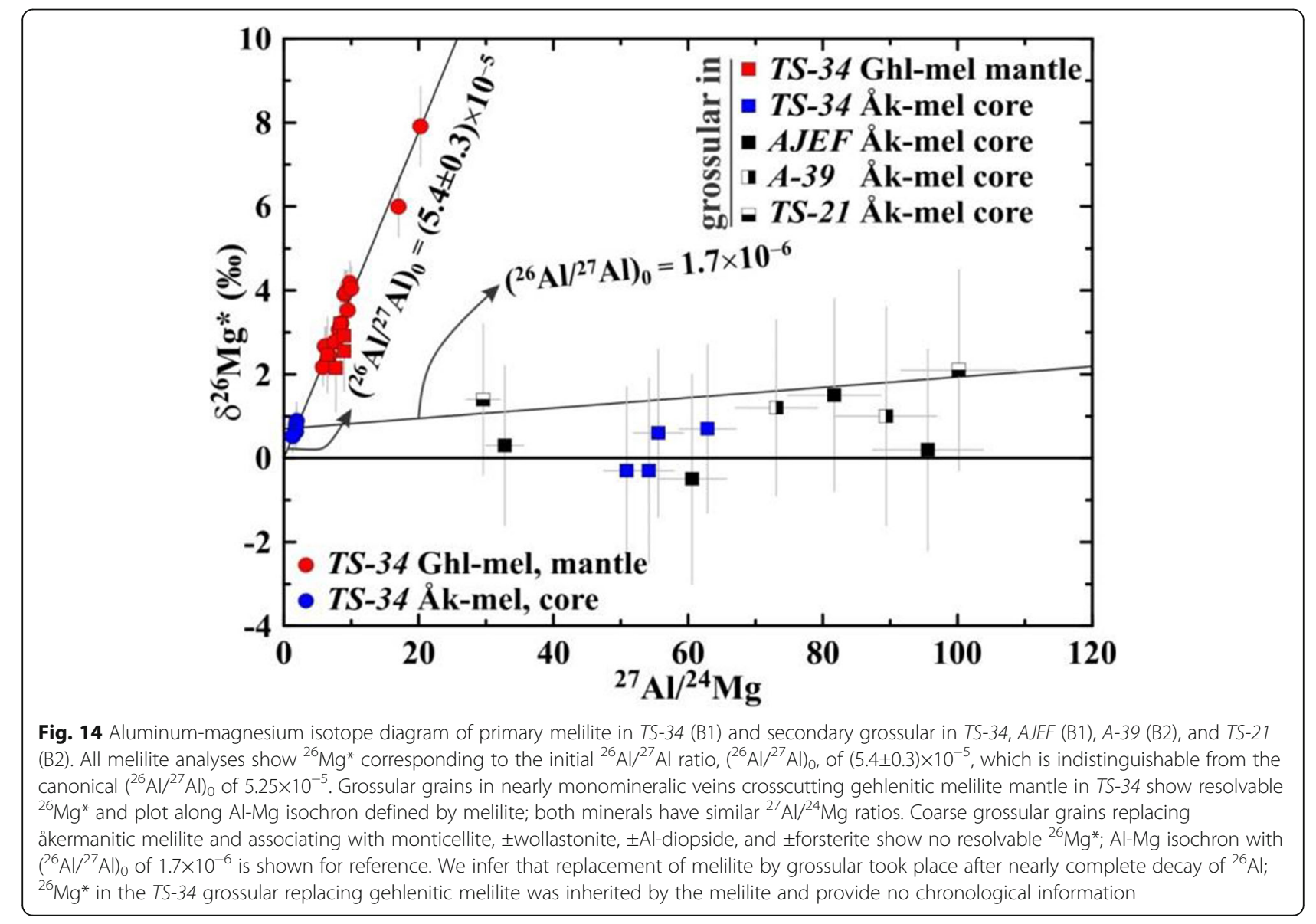

Fig. 14 Aluminum-magnesium isotope diagram of primary melilite in TS-34 (B1) and secondary grossular in TS-34, AJEF (B1), A-39 (B2), and TS-21 (B2). All melilite analyses show ${ }^{26} \mathrm{Mg}^{*}$ corresponding to the initial ${ }^{26} \mathrm{Al} /{ }^{27} \mathrm{Al}$ ratio, $\left({ }^{26} \mathrm{Al} /{ }^{27} \mathrm{Al}\right)_{0}$, of $(5.4 \pm 0.3) \times 10^{-5}$, which is indistinguishable from the canonical $\left({ }^{26} \mathrm{Al} /{ }^{27} \mathrm{Al}\right)_{0}$ of $5.25 \times 10^{-5}$. Grossular grains in nearly monomineralic veins crosscutting gehlenitic melilite mantle in TS-34 show resolvable ${ }^{26} \mathrm{Mg}^{*}$ and plot along Al-Mg isochron defined by melilite; both minerals have similar ${ }^{27} \mathrm{Al} /{ }^{24} \mathrm{Mg}$ ratios. Coarse grossular grains replacing åkermanitic melilite and associating with monticellite, \pm wollastonite, \pm Al-diopside, and \pm forsterite show no resolvable ${ }^{26} \mathrm{Mg}^{*}$; Al-Mg isochron with $\left({ }^{26} \mathrm{Al} /{ }^{27} \mathrm{Al}\right)_{0}$ of $1.7 \times 10^{-6}$ is shown for reference. We infer that replacement of melilite by grossular took place after nearly complete decay of ${ }^{26} \mathrm{Al}$; ${ }^{26} \mathrm{Mg}^{*}$ in the TS-34 grossular replacing gehlenitic melilite was inherited by the melilite and provide no chronological information
The released calcium (reactions (R) 4, 7, 8, and 9) could have precipitated as a layer of $\mathrm{Ca}, \mathrm{Fe}$-rich silicates (salite-hedenbergite pyroxenes, andradite and wollastonite) outside and inside fine-grained rims surrounding altered CAIs (see below).

\subsubsection{Alteration of åkermanitic melilite}

Åkermanitic melilite in Type B2s, FoBs, cores of B1s, and CTA CAI TS-2 is replaced by three major secondary minerals assemblages: $(i)$ grossular + monticellite + 
wollastonite (R11), (ii) grossular + monticellite (R12), and (iii) grossular + Al-diopside (R7); minor secondary minerals include clintonite, forsterite, and spinel. Again, the presence of clintonite and margarite (this study; Keller and Buseck 1991) in the secondary mineral assemblages requires the presence of $\mathrm{H}_{2} \mathrm{O}$ during alteration reactions:

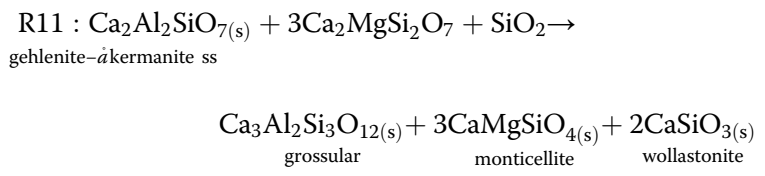

$\mathrm{R} 12: \mathrm{Ca}_{2} \mathrm{Al}_{2} \mathrm{SiO}_{7(\mathrm{~s})}+2 \mathrm{Ca}_{2} \mathrm{MgSi}_{2} \mathrm{O}_{7} \rightarrow$

gehlenite-áa kermanite ss

$$
\underset{\text { grossular }}{\mathrm{Ca}_{3} \mathrm{Al}_{2} \mathrm{Si}_{3} \mathrm{O}_{12(\mathrm{~s})}}+\underset{\text { monticellite }}{2 \mathrm{CaMgSiO}_{4(\mathrm{~s})}}+\mathrm{CaO}
$$

$$
\begin{aligned}
& \text { R13 : } \mathrm{Ca}_{2} \mathrm{Al}_{2} \mathrm{SiO}_{7(\mathrm{~s})}+\mathrm{Ca}_{2} \mathrm{MgSi}_{2} \mathrm{O}_{7}+\mathrm{SiO}_{2} \rightarrow \\
& \text { gehlenite- } a \text { kermanite ss } \\
& \underset{\text { grossular }}{\mathrm{Ca}_{3} \mathrm{Al}_{2} \mathrm{Si}_{3} \mathrm{O}_{12(\mathrm{~s})}}+\underset{\text { monticellite }}{\mathrm{CaMgSiO}_{4(\mathrm{~s})}}
\end{aligned}
$$

In some cases, grossular + monticellite + wollastonite assemblages are subsequently replaced by Al-diopside (Fig. 9a-d):

$$
\begin{aligned}
& \underset{\text { grossular }}{\mathrm{R} 14: \mathrm{Ca}_{3} \mathrm{Al}_{2} \mathrm{Si}_{3} \mathrm{O}_{12(\mathrm{~s})}}+\underset{\text { monticellite }}{\mathrm{CaMgSiO}_{4(\mathrm{~s})}}+\underset{\text { wollastonite }}{\mathrm{CaSiO}_{3(\mathrm{~s})}} \rightarrow \\
& \mathrm{CaMgSi}_{2} \mathrm{O}_{6(\mathrm{~s})}+\mathrm{CaAl}_{2} \mathrm{SiO}_{6(\mathrm{~s})}+2 \mathrm{SiO}_{2}+3 \mathrm{CaO}
\end{aligned}
$$

The released calcium and silica may have been used to form a new generation of wollastonite that either crosscuts the earlier formed secondary mineral assemblages or fills the voids in the CAI interiors (Figs. 9 and 10a):

$$
\mathrm{R} 15: \mathrm{CaO}+\mathrm{SiO}_{2} \rightarrow \mathrm{CaSiO}_{3(\mathrm{~s})}
$$

These elements may have been also used to form a layer of $\mathrm{Ca}$,Fe-rich silicates (salite-hedenbergite pyroxenes, andradite, and wollastonite) outside fine-grained rims around CAIs (see below).

\subsubsection{Alteration of lacy melilite}

In contrast to the preferential replacement of coarse åkermanitic melilite grains in Type B and FoB CAIs, in Type Cs, lacy melilite grains composed of åkermanitic melilite and anorthite are pseudomorphically replaced by the grossular + monticellite + forsterite (R16) and by grossular $+\mathrm{Al}$-diopside assemblages (R17). The pseudomorphs contain neither clintonite nor margarite, and are surrounded by the virtually unaltered fine-grained anorthite groundmass, suggesting the alteration may have occurred under nearly dry conditions:

$$
\begin{aligned}
& \text { R16 : } \mathrm{Ca}_{2} \mathrm{Al}_{2} \mathrm{SiO}_{7(\mathrm{~s})}+3 \mathrm{Ca}_{2} \mathrm{MgSi}_{2} \mathrm{O}_{7}+ \\
& \text { gehlenite- } \dot{a} \text { kermanite ss } \\
& \underset{\text { anorthite }}{2 \mathrm{CaAl}_{2} \mathrm{Si}_{2} \mathrm{O}_{8(\mathrm{~s})}} \rightarrow \underset{\text { grossular }}{\underset{\text { monticellite }}{\mathrm{CaMgSiO}_{4(\mathrm{~s})}}}+\underset{\text { forsterite }}{\mathrm{Mg}_{2} \mathrm{SiO}_{4(\mathrm{~s})}}
\end{aligned}
$$

R17 : $\mathrm{Ca}_{2} \mathrm{Al}_{2} \mathrm{SiO}_{7(\mathrm{~s})}+2 \mathrm{Ca}_{2} \mathrm{MgSi}_{2} \mathrm{O}_{7}+$

gehlenite-áa kermanite ss

$$
\begin{aligned}
& \underset{\text { anorthite }}{\mathrm{CaAl}_{2} \mathrm{Si}_{2} \mathrm{O}_{8(\mathrm{~s})}}+\mathrm{SiO}_{2} \rightarrow \underset{\text { grossular }}{\mathrm{Ca}_{3} \mathrm{Al}_{2} \mathrm{Si}_{3} \mathrm{O}_{12(\mathrm{~s})}}+ \\
& 2 \mathrm{CaMgSi}_{2} \mathrm{O}_{6}+\mathrm{CaAl}_{2} \mathrm{SiO}_{6(\mathrm{~s})}+\mathrm{CaO} \\
& \text { diopside-Ca-Tschermakite ss }
\end{aligned}
$$

$$
\begin{aligned}
& \text { R18: } \mathrm{Ca}_{2} \mathrm{Al}_{2} \mathrm{SiO}_{7(\mathrm{~s})}+\mathrm{Ca}_{2} \mathrm{MgSi}_{2} \mathrm{O}_{7}+ \\
& \text { gehlenite- } a \text { kermanite ss }
\end{aligned}
$$

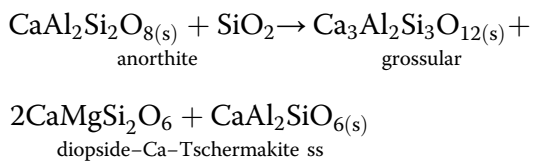

The pseudomorphically replaced lacy melilite grains are surrounded by a thin discontinuous rim of $\mathrm{Na}$-rich melilite (Fig. 8b, d). Because the primary åkermanitic melilite contains $0.1-0.3 \mathrm{wt} \% \mathrm{Na}_{2} \mathrm{O}$ (Table 1), it is possible that sodium in the Na-rich melilite may have had a local origin, i.e., it may be a byproduct of alteration of the primary Na-bearing åkermanitic melilite. The preferential occurrence of Na-melilite along edges of lacy melilite pseudomorphs may reflect normal igneous zoning of the lacy melilite grains: a positive correlation between $\mathrm{Na}_{2} \mathrm{O}$ and åkermanite content in melilite was described in many igneous CV CAIs (e.g., Beckett and Grossman 1988; Beckett et al. 2000; Simon and Grossman 2006). A similar origin could be inferred for $\mathrm{Na}$ melilite in all Allende containing Na-bearing igneous åkermanitic melilite (Fig. 7).

\subsubsection{Alteration of primary and secondary anorthite}

The occurrences of primary igneous anorthite depend on the CAI types: In type B1 CAIs, it occurs in the CAI cores; in Type B2 CAIs, it occurs throughout the inclusions (Fig. 1g, k, m). Secondary anorthite occurs almost exclusively in the peripheral regions of the Allende CAIs 
where it replaces gehlenitic melilite (Fig. 1). Primary and secondary anorthites in the peripheral portions of the Allende CAIs are largely replaced by nepheline, sodalite, and ferromagesian olivine:

$$
\begin{aligned}
& \text { R19: } \underset{\text { anorthite }}{\mathrm{CaAl}_{2} \mathrm{Si}_{2} \mathrm{O}_{8(\mathrm{~s})}}+\underset{\text { nepheline }}{\mathrm{Na}_{2} \mathrm{O} \rightarrow 2 \mathrm{NaAlSiO}_{4(\mathrm{~s})}}+\mathrm{CaO} \\
& \mathrm{R} 20: \underset{\text { anorthite }}{3 \mathrm{CaAl}_{2} \mathrm{Si}_{2} \mathrm{O}_{8(\mathrm{~s})}+3 \mathrm{Na}_{2} \mathrm{O}+2 \mathrm{NaCl} \rightarrow} \\
& \mathrm{Na}_{8} \mathrm{Al}_{6} \mathrm{Si}_{6} \mathrm{O}_{24} \mathrm{Cl}_{2(\mathrm{~s})}+3 \mathrm{CaO}
\end{aligned}
$$

The magnesium content in primary and secondary anorthite is too low and iron is essentially absent, so the presence of secondary ferromagnesian olivine associated with nepheline and sodalite requires an external source of these elements, perhaps matrix. We suggest that $\mathrm{Mg}$, $\mathrm{Fe}$, and likely $\mathrm{SiO}_{2}$ were supplied to the host inclusions by an external aqueous solution:

$$
\begin{aligned}
\mathrm{R} 21: & \mathrm{Mg}^{2+}{ }_{(\mathrm{aq})}+\mathrm{Fe}^{2+}{ }_{(\mathrm{aq})}+\mathrm{SiO}_{2(\mathrm{aq})} \\
& +2 \mathrm{H}_{2} \mathrm{O}_{(\mathrm{aq})} \rightarrow(\mathrm{Fe}, \mathrm{Mg})_{2} \mathrm{SiO}_{4(\mathrm{~s})}+4 \mathrm{H}^{+}{ }_{(\mathrm{aq})}
\end{aligned}
$$

4.6 Zoned distribution of $\mathrm{Na}$ - and $\mathrm{Cl}$-bearing minerals and $\mathrm{Ca}$,Fe-rich silicates in and around Allende CAls: Evidence for in situ open-system metasomatic alteration of the Allende CAls

The observed depletion in calcium and enrichment in silicon in altered gehlenitic melilite regions, the presence of a $\mathrm{Ca}, \mathrm{Fe}$-rich silicate layer outside fine-grained rims around altered CAIs, and the zoned distribution of $\mathrm{Na}$ - and $\mathrm{Cl}$ bearing minerals (nepheline, sodalite, and wadalite) in and around Allende CAIs (Fig. 1) provide clear evidence for an open-system behavior of several elements $(\mathrm{Si}, \mathrm{Na}, \mathrm{Cl}, \mathrm{Ca}$, and $\mathrm{Al}$ ) during in situ metasomatic alteration of these CAIs: $\mathrm{Si}, \mathrm{Na}$, and $\mathrm{Cl}$ were added, whereas $\mathrm{Ca}$ and, probably, some Al were removed from the inclusions. The mobility of aluminum during the alteration is consistent with the presence of grossular, kushiroite, and Na-rich melilite in veins crosscutting primary anorthite grains inside the inclusions (e.g., Fig. 7f). The outward transport of dissolved $\mathrm{Al}$ from CAIs and the influx of $\mathrm{Na}, \mathrm{K}$, and $\mathrm{Si}$ with an aqueous fluid equilibrated with the Allende matrix could explain the abundant nepheline grains in finegrained rims around Allende CAIs studied (Figs. 1 and 2):

$$
\begin{aligned}
\mathrm{R} 22: & \mathrm{Na}^{+}{ }_{(\mathrm{aq})}+\mathrm{Al}^{3+}{ }_{(\mathrm{aq})}+\mathrm{SiO}_{2(\mathrm{aq})} \\
& +2 \mathrm{H}_{2} \mathrm{O}_{(\mathrm{aq})} \rightarrow \mathrm{NaAlSiO}_{4(\mathrm{~s})}+4 \mathrm{H}^{+}{ }_{(\mathrm{aq})}
\end{aligned}
$$

The fact that fine-grained rims lack sodalite may indicate an earlier formation of nepheline than sodalite. A similar conclusion was reached by Che and Brearley (2021) based on the zoned distribution of nepheline and sodalite within Allende CAIs.

Wark (1981) interpreted the presence of alkali-rich halos around altered Allende CAIs as an evidence for outward diffusion of volatiles and suggested that the alteration occurred in the solar nebula prior to incorporation of CAIs into the Allende meteorite. We conclude instead that this interpretation is incorrect and cannot be used as evidence for nebular alteration.

Calcium released during replacement of gehlenitic melilite by anorthite (R4) and subsequently by nepheline and sodalite (R19, R20) may have interacted with Fe-, $\mathrm{Mg}$ - and Si-enriched fluid that most likely was in equilibrium with the Allende fine-grained matrix (Krot et al. 2001b; Ganino and Libourel 2017). This process resulted in precipitation of $\mathrm{Ca}, \mathrm{Fe}$-rich silicates at the boundary between fine-grained rims and the Allende matrix (Figs. 1 and 2) and, occasionally, within fine-grained rims (Fig. 2b):

$$
\begin{aligned}
& \mathrm{R} 23: \mathrm{Ca}^{2+}{ }_{(\mathrm{aq})}+\mathrm{Fe}^{2+}{ }_{(\mathrm{aq})}+2 \mathrm{SiO}_{2(\mathrm{aq})} \\
& +2 \mathrm{H}_{2} \mathrm{O}_{(\mathrm{aq})} \rightarrow \underset{\text { hedenbergite }}{\mathrm{CaFeSi}_{2} \mathrm{O}_{6(\mathrm{~s})}+4 \mathrm{H}^{+}{ }_{(\mathrm{aq})}} \\
& \mathrm{R} 24: 3 \mathrm{Ca}^{2+}{ }_{(\mathrm{aq})}+2 \mathrm{Fe}^{3+}{ }_{(\mathrm{aq})}+3 \mathrm{SiO}_{2(\mathrm{aq})} \\
& +6 \mathrm{H}_{2} \mathrm{O}_{(\mathrm{aq})} \rightarrow \underset{\text { andradite }}{\mathrm{Ca}_{3} \mathrm{Fe}_{2} \mathrm{Si}_{3} \mathrm{O}_{12(\mathrm{~s})}+12 \mathrm{H}^{+}{ }_{(\mathrm{aq})}} \\
& \begin{aligned}
\mathrm{R} 25 & \mathrm{Ca}^{2+}{ }_{(\mathrm{aq})}+\mathrm{SiO}_{2(\mathrm{aq})} \\
& +\mathrm{H}_{2} \mathrm{O}_{(\mathrm{aq})} \rightarrow \underset{\text { wollastonite }}{\mathrm{CaSiO}_{3(\mathrm{~s})}+2 \mathrm{H}^{+}{ }_{(\mathrm{aq})}}
\end{aligned} \\
& \mathrm{R} 26: \mathrm{Ca}^{2+}{ }_{(\mathrm{aq})}+0.5 \mathrm{Fe}^{2+}{ }_{(\mathrm{aq})}+0.5 \mathrm{Mg}^{2+}{ }_{(\mathrm{aq})} \\
& +2 \mathrm{SiO}_{2(\mathrm{aq})} \\
& +2 \mathrm{H}_{2} \mathrm{O}_{(\mathrm{aq})} \rightarrow \mathrm{Ca}(\mathrm{Fe}, \mathrm{Mg}) \mathrm{Si}_{2} \mathrm{O}_{6(\mathrm{~s})}+4 \mathrm{H}^{+}{ }_{(\mathrm{aq})} \\
& \text { salite-hedenbergite ss }
\end{aligned}
$$

The preferential precipitation of $\mathrm{Ca}, \mathrm{Fe}$-rich silicates outside fine-grained rims may be due to a relatively compact nature of these rims compared to the boundaries between rims and matrix, where a geochemical barrier between fluids of different compositions, Ca-rich and $\mathrm{Fe}, \mathrm{Mg}$,Si-rich, which were in equilibrium with the host CAIs and surrounding matrix, respectively, could have been generated. 
4.7 Evidence for multistage metasomatic alteration of the Allende CAls and variations in chemical composition of the metasomatic fluids

Our mineralogical observations indicate that metasomatic alteration of the Allende coarse-grained CAIs was multistage and resulted in the formation of multiple generations of secondary minerals. These include $(i)$ replacement of grossular + monticellite + wollastonite mineral assemblages by Al-diopside (Fig. 9a-d), (ii) wollastonite veins crosscutting grossular + monticellite + wollastonite mineral assemblages (Fig. 9e, f), (iii) crosscutting relationships between grossular-rich veins and veins containing abundant iron-rich minerals (andradite, hedenbergite, ferroan Al-diopside, ferroan monticellite, pentlandite, and heazlewoodite) (Fig. 11); (iv) overgrowth of monticellite by ferroan monticellite (Fig. 10i); (v) overgrowth of Al-diopside by ferroan grossular (Fig. 10g); (vi) overgrowth of grossular by ferroan grossular and andradite (Figs. 3 and 10g-j and h); (vii) oscillatory zoning of grossular and Al-diopside grains (Fig. 10b-h); (viii) replacement of secondary anorthite by nepheline, sodalite, and ferromagnesian olivine (Figs. 1 and 6c, d). In most cases, the later formed secondary minerals contain higher iron content than the earlier ones. These observations suggest that alteration occurred in the presence of aqueous solutions of variable chemical compositions.

\subsection{Physico-chemical analysis of alteration reactions inferred in Allende CAls}

4.8.1 Transport of elements in aqueous solution and steam during metasomatic alteration of Allende CAls

Mineralogical and petrographic observations "Petrography and primary mineralogy of the Allende coarsegrained igneous CAIs", chemical compositions of secondary phases, and the inferred chemical reactions "Secondary mineral assemblages in the Allende CAIs and inferred metasomatic reactions", "Zoned distribution of $\mathrm{Na}$ - and $\mathrm{Cl}$-bearing minerals and $\mathrm{Ca}, \mathrm{Fe}-$ rich silicates in and around Allende CAIs: Evidence for in situ open-system metasomatic alteration of the Allende CAIs", "Evidence for multistage metasomatic alteration of the Allende CAIs and variations in chemical composition of the metasomatic fluids" suggest the involvement of water in metasomatic alteration of $\mathrm{CV}$ chondrites and their components (see also Brearley and Krot 2013; Ganino and Libourel 2017). The altered patches and veins in mantles and cores of the Allende coarse-grained CAIs are dominated by $\mathrm{Ca}, \mathrm{Al}, \mathrm{Mg}$-rich phases which are enriched in $\mathrm{SiO}_{2}$ and depleted in $\mathrm{CaO}$ compared to the primary phases. Such mineralogy requires an efficient addition of $\mathrm{Si}$ to and removal of $\mathrm{Ca}$ from CAIs. Most secondary ferromagnesian silicates in CAI interiors- forsterite, monticellite, and Al-diopside-are essentially Fe-free compared to the ferroan olivine, kirschsteinite, and salite-hedenbergite in fine-grained rims and neighboring matrix. It appears that for some reason the Fe, abundant in an aqueous solution circulating through the Allende matrix (Krot et al. 1998a, 1998b; Ganino and Libourel 2017), has not been efficiently delivered to the interiors of the Allende coarse-grained igneous CAIs. The same may be true for $\mathrm{Na}$ and $\mathrm{Cl}$ which are predicted to have high concentrations in an aqueous solution equilibrated with matrix (Petaev and Moronenko 1997), but in wadalite replacing åkermanitic melilite in Type B CAIs, these elements are decoupled from each other.

While the source of water on chondritic parent bodies remains speculative, the accretion of $\mathrm{H}_{2} \mathrm{O}$-rich ices alongside other nebular components is considered the most plausible mechanism (Krot et al. 2015). Upon subsequent heating, either internal or impactinduced, the ices sublimate and/or melt to generate $\mathrm{H}_{2} \mathrm{O}$ steam or liquid water or, most likely, both. The liquid water and steam would react with the surrounding minerals and amorphous phases and leach out some chemical elements to transform initially nearly pure water to an aqueous solution with concentrations of $\mathrm{SiO}_{2}, \mathrm{Fe}^{2+}, \mathrm{Mn}^{2+}, \mathrm{Ca}^{2+}, \mathrm{Mg}^{2+}, \mathrm{Na}^{+}$, $\mathrm{Cl}^{-}, \mathrm{HCO}_{3}{ }^{-}$, and other ions and neutral aqueous species gradually increasing with time. Such a solution is capable transporting of $\mathrm{Ca}, \mathrm{Mn}, \mathrm{Fe}, \mathrm{Si}, \mathrm{Na}$, and $\mathrm{Cl}$ at low temperatures. The ability of steam to transport at least some of these elements depends upon P-T conditions. The numerous experimental and natural data suggest that in terrestrial hydrothermal environments a supercritical fluid $(\mathrm{T}>647 \mathrm{~K}, \mathrm{P}$ $>22 \mathrm{MPa}$ ) can efficiently transport these elements too, but the estimates of the Allende tensile strength imply that a gas pressure in excess of $\sim 10 \mathrm{MPa}$ should break the rock and release the gas (Grimm and McSween Jr. 1989). Thus, the presence of supercritical fluid on the $\mathrm{CV}$ parent body seems unlikely. Still, a low-density steam, either subcritical saturated $\left(\mathrm{P}_{\mathrm{H} 2 \mathrm{O}}=\mathrm{P}_{\mathrm{H} 2 \mathrm{O}}\right.$, equil, $\left.\mathrm{T}<647 \mathrm{~K}\right)$ or dry superheated $\left(\mathrm{P}_{\mathrm{H} 2 \mathrm{O}}<\mathrm{P}_{\mathrm{H} 2 \mathrm{O}}\right.$, equil, $\left.\mathrm{T}>647 \mathrm{~K}\right)$, can spread out of the aqueous solution source region and carry chemical species dissolved in it. Such a steam seems to be of low interest for geochemists, but it is a source of great concern in the steam power industry because it results in the deposition of solids on turbine blades and corrodes them.

A classic review of experimental data on concentrations of different solutes in subcritical and dry superheated steam (Harvey and Bellows 1997) shows that significant amounts of $\mathrm{SiO}_{2}, \mathrm{NaCl}, \mathrm{NaOH}, \mathrm{Na}_{2} \mathrm{SO}_{4}$, $\mathrm{Na}_{3} \mathrm{PO}_{4}$, and $\mathrm{Fe}$ oxides orders of magnitude higher 
than would be expected on their vapor pressures, can be dissolved in steam in the form of solvated complexes (e.g., $\mathrm{SiO}_{2} \cdot \mathrm{mH}_{2} \mathrm{O}$ ). The concentration of a solute $\left(\mathrm{X}_{\mathrm{s}}\right)$ in the steam depends upon temperature $(\mathrm{T})$, pressure $(P)$, and steam density $(\rho)$ as described by empirical equations

$$
\begin{aligned}
\ln \left(\mathrm{X}_{\mathrm{s}}\right)= & \mathrm{A}+\mathrm{B} / \mathrm{T}+\left(\mathrm{m}_{1}+\mathrm{m}_{3} / \mathrm{T}\right) \\
& \times \ln \rho-\ln \mathrm{P}
\end{aligned}
$$

or

$$
\begin{aligned}
\ln \left(\mathrm{X}_{\mathrm{s}}\right)= & \mathrm{A}+\mathrm{D} \times \mathrm{T} \\
& +\left(\mathrm{m}_{1}+\mathrm{m}_{2} \times \rho \times \mathrm{m}_{3} \times \mathrm{T}\right) \\
& \times \ln \rho-\ln \mathrm{P}
\end{aligned}
$$

where $A, B, D, m_{1}, m_{2}$, and $m_{3}$ are regression coefficients specific for each solute. Because of generally low distribution coefficients of these solutes between a "parental" aqueous solution and the steam equilibrated with it, subsequent condensation of such a steam would produce a "secondary" aqueous solution containing much lower concentrations of solutes than its "parental" solution. The "secondary" solution should be essentially free of solutes which cannot be efficiently transported by the steam. Because of the low solubility of iron oxides in water under oxidizing conditions, the equilibrium concentrations of iron oxides in the steam are negligible. Calcium concentrations in steam are also expected to be low because of very low distribution coefficients of $\mathrm{CaCl}_{2}$ and $\mathrm{CaSO}_{4}$ between an aqueous solution and steam derived from it (e.g., Svoboda 2006). Apparently, neither $\mathrm{Fe}$ nor $\mathrm{Ca}$ can be efficiently transported by the steam.

\subsubsection{Physico-chemical analysis of alteration reactions}

The inferences about the involvement of an aqueous solution or $\mathrm{H}_{2} \mathrm{O}$ steam or both in the alteration process can be made based on a physicochemical analysis of the observed and/or possible alteration reactions and the textural relationships and mineral crystallization sequences in altered refractory inclusions. The textures and mineral chemistry of altered areas leave no doubt that an aqueous alteration was a non-equilibrium, multistage process, with many observed reactions not going to completion (see Alteration of primary and secondary minerals in the Allende CAIs). Given the multitude of such non-equilibrium effects, considering them would make the problem intractable. Instead, we employ here an equilibrium approach in evaluating intensive parameters of the observed alteration reactions assuming that they have reached a steady state. Then, in order to evaluate the plausibility of these reactions, the calculated values of fugacities and activities of different gaseous and aqueous species for each reaction are compared with each other and with independent estimates of these parameters. The thermodynamic data for solid, gaseous, and aqueous species are taken from compilations of Robie and Hemingway (1995) and Oelkers et al. (1995), except for the gaseous $\mathrm{H}_{4} \mathrm{SiO}_{4}$ (Plyasunov 2011) and sodalite (Komada et al. 1995). The gaseous and solid solutions are treated as ideal. For the sake of temperature interpolation, the tabulated data were fitted with polynomials, with the deviation between fitted and tabulated data being typically $<0.1 \%$. For the aqueous species, we have adopted the lowest pressure $(0.004-16.55 \mathrm{MPa})$ tabulation set for the $25-350{ }^{\circ} \mathrm{C}$ temperature range, with the pressure at any given temperature being equal to the partial pressure of the saturated $\mathrm{H}_{2} \mathrm{O}$ vapor; i.e., the gaseous phase involved in alteration reactions is nearly pure $\mathrm{H}_{2} \mathrm{O}$ steam equilibrated with an aqueous solution at any given temperature.

For the same conditions, we calculated maximum concentrations of solutes in the steam and the aqueous solution formed by its condensation (Fig. 15), using equations and regression parameters of Harvey and Bellows (1997). The rather high concentrations of $\mathrm{SiO}_{2}, \mathrm{Na}$, and $\mathrm{Cl}$ in both the steam and aqueous solution, especially at higher temperatures and pressures, imply that these elements potentially can be supplied to the CAIs from an aqueous solution equilibrated with matrix without the addition of $\mathrm{Fe}$ and $\mathrm{Ca}$ insoluble in steam. This may explain the Fe-rich and Fepoor secondary mineralogy in the matrix and refractory inclusions, respectively. However, because both $\mathrm{Na}$ and $\mathrm{Cl}$ can be efficiently transported by the steam, they are not expected to decouple unless steam formed at an early stage of alteration contains only Cl-bearing species such as $\mathrm{HCl}$ and $\mathrm{NH}_{4} \mathrm{Cl}$ which might have been present in accreted ices (e.g., Zolotov and Mironenko 2007).

Because $\mathrm{SiO}_{2}, \mathrm{CO}_{2}, \mathrm{Na}$, and $\mathrm{Cl}$ can be transported by steam, the reaction involving these elements do not require an aqueous solution to be in direct contact with the solid phases, while the reactions involving $\mathrm{Ca}, \mathrm{Fe}$, and $\mathrm{Mg}$ need an aqueous solution for addition and/or removal of these elements. The inferred alteration reactions are divided into several groups based on chemical elements added to and/or removed from the primary mineral assemblages of CAIs: (1) $\mathrm{SiO}_{2}$ only, (2) $\mathrm{CO}_{2}$ only, (3) $\mathrm{SiO}_{2}, \mathrm{CO}_{2}$, and $\mathrm{Ca}$, (4) $\mathrm{Na} \pm \mathrm{Cl}$ and $\mathrm{Ca} \pm \mathrm{SiO}_{2}$, (5) $\mathrm{Fe}, \mathrm{Mg}, \mathrm{Ca}, \mathrm{SiO}_{2}$.

The physico-chemical conditions of reactions describing the formation of $\mathrm{Fe}, \mathrm{Mg}$, Ca-bearing silicates during aqueous alteration have been previously evaluated by us (Krot et al. 1998b, 2001b) and are not considered here. They should be fully consistent with the current work because we use essentially the same approach and thermodynamic databases. 


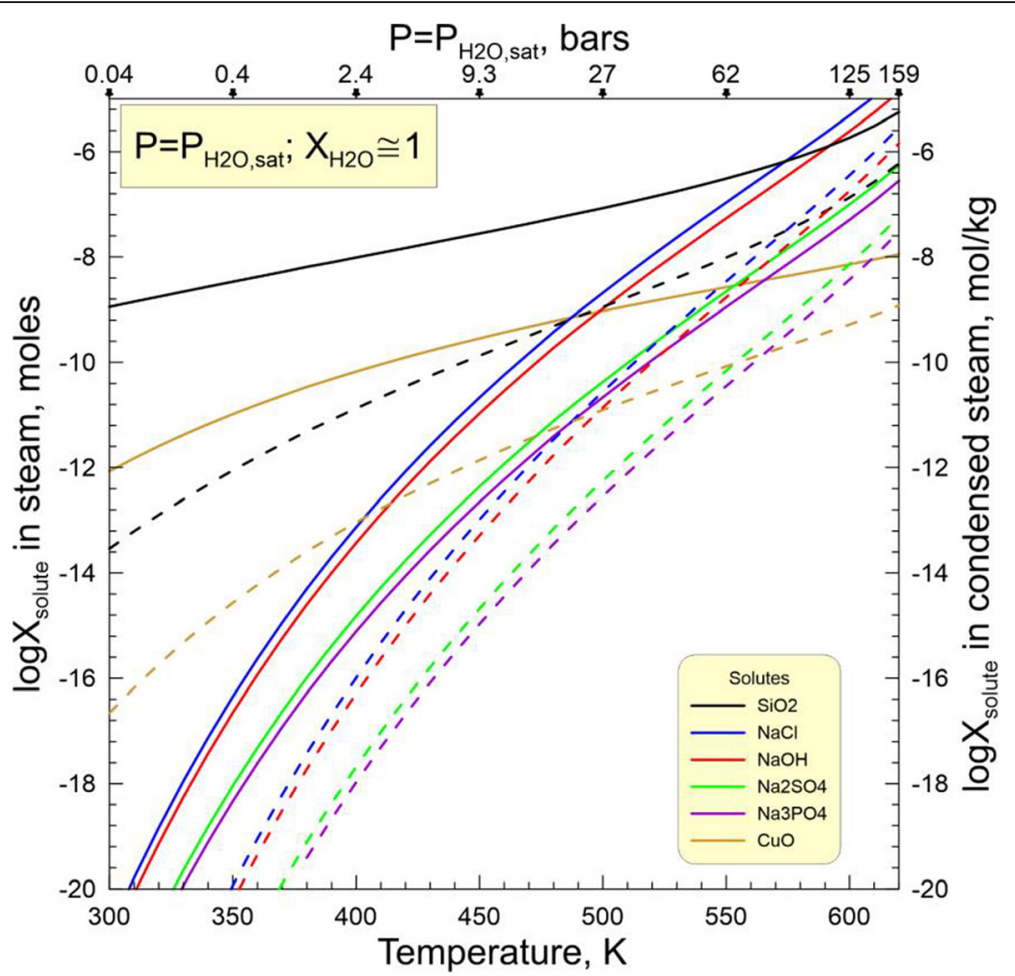

Fig. 15 Maximium solubility of different solutes in the saturated $\mathrm{H}_{2} \mathrm{O}$ steam (solid lines) and the aqueous solution formed by its condensation (dashed lines)

To evaluate whether an observed alteration reaction can proceed via the gaseous phase only or requires a direct contact with an aqueous solution, one has to write appropriate reaction equations, calculate their intensive parameters, and compare them with each other and independent data if such exist. For example, reaction 7 can be described by the following equations:

$$
\begin{aligned}
\mathrm{R} 7 g: & 2 \mathrm{Ca}_{2} \mathrm{Al}_{2} \mathrm{SiO}_{7(\mathrm{~s})}+\mathrm{Ca}_{2} \mathrm{MgSi}_{2} \mathrm{O}_{7(\mathrm{~s})} \\
& +2 \mathrm{H}_{4} \mathrm{SiO}_{4(\mathrm{~g})}+4 \mathrm{CO}_{2(\mathrm{~g})} \\
= & \mathrm{Ca}_{3} \mathrm{Al}_{2} \mathrm{Si}_{3} \mathrm{O}_{12(\mathrm{~s})}+\mathrm{CaMgSi}_{2} \mathrm{O}_{6(\mathrm{~s})} \\
& +\mathrm{CaAl}_{2} \mathrm{SiO}_{6(\mathrm{~s})}+\mathrm{Ca}^{2+}(\mathrm{aq}) \\
& +4 \mathrm{HCO}_{3}{ }_{(\mathrm{aq})}^{-}+\mathrm{H}_{2(\mathrm{~g})}+\mathrm{H}_{2} \mathrm{O}_{(\mathrm{aq})} \\
& \\
\operatorname{lgK} \mathrm{K}_{7 g}= & \lg \left[\mathrm{X}_{\mathrm{Di}}\right]+\lg \left[\mathrm{X}_{\mathrm{Cts}}\right]+\lg \left[\mathrm{Ca}^{2+}\right]+4 \lg \left[\mathrm{HCO}_{3}{ }^{-}\right] \\
& +\operatorname{lgP} \mathrm{H}_{\mathrm{H} 2}-2 \lg \mathrm{H}_{44 \mathrm{SiO}}-2 \lg \left[\mathrm{X}_{\mathrm{Gel}}\right]-\lg \left[\mathrm{X}_{\dot{A} \mathrm{k}]}-4 \mathrm{lgP}_{\mathrm{CO} 2}\right.
\end{aligned}
$$

$\mathrm{R} 7 a q: 2 \mathrm{Ca}_{2} \mathrm{Al}_{2} \mathrm{SiO}_{7(\mathrm{~s})}+\mathrm{Ca}_{2} \mathrm{MgSi}_{2} \mathrm{O}_{7(\mathrm{~s})}$

$$
\begin{aligned}
+ & 2 \mathrm{SiO}_{2(\mathrm{aq})}+4 \mathrm{CO}_{2(\mathrm{~g})}+3 \mathrm{H}_{2} \mathrm{O}_{(\mathrm{aq})} \\
= & \mathrm{Ca}_{3} \mathrm{Al}_{2} \mathrm{Si}_{3} \mathrm{O}_{12(\mathrm{~s})}+\mathrm{CaMgSi}_{2} \mathrm{O}_{6(\mathrm{~s})} \\
& +\mathrm{CaAl}_{2} \mathrm{SiO}_{6(\mathrm{~s})}+\mathrm{Ca}^{2+}{ }_{(\mathrm{aq})} \\
& +4 \mathrm{HCO}_{3}{ }^{-}{ }_{(\mathrm{aq})}+\mathrm{H}_{2(\mathrm{~g})}
\end{aligned}
$$

$$
\begin{aligned}
\lg \mathrm{K}_{7 a q}= & \lg \left[\mathrm{X}_{\mathrm{Di}}\right]+\lg \left[\mathrm{X}_{\mathrm{CTs}}\right]+2 \lg \left[\mathrm{Ca}^{2+}\right] \\
& +4 \lg \left[\mathrm{HCO}_{3}{ }^{-}\right]-2 \lg \left[\mathrm{SiO}_{2}\right]-2 \lg \left[\mathrm{X}_{\mathrm{Gel}}\right] \\
& -2 \lg \left[\mathrm{X}_{\dot{A} \mathrm{k}]-4 \operatorname{lgP}}{ }_{\mathrm{CO} 2}\right.
\end{aligned}
$$

where subscripts $s, g$, and $a q$ denote solid, gaseous, and aqueous species, respectively; $\mathrm{X}_{\mathrm{Di}}, \mathrm{X}_{\mathrm{CTs}}, \mathrm{X}_{\mathrm{Gel}}$, and $\mathrm{X}_{\mathrm{A} k}$ are mole fractions of diopside, Ca-Tschermakite, gehlenite, and åkermanite, respectively, in Al-diopside and melilte solid solutions; $\mathrm{P}_{\mathrm{H} 2}, \mathrm{P}_{\mathrm{H} 4 \mathrm{SiO} 4}$, and $\mathrm{P}_{\mathrm{CO} 2}$ are partial pressures of $\mathrm{H}_{2}, \mathrm{H}_{4} \mathrm{SiO}_{4}$ and $\mathrm{CO}_{2}$ in the gaseous phase dominated by $\mathrm{H}_{2} \mathrm{O}$; and $\left[\mathrm{Ca}^{2+}\right],\left[\mathrm{HCO}_{3}{ }^{-}\right]$, and $\left[\mathrm{SiO}_{2}\right]$ are activities of ions and neutral species in the aqueous solution. Note, that $\mathrm{Si}$ and $\mathrm{C}$ in the reaction $\mathrm{R} 7 g$ are supplied via gaseous phase, but the removal of $\mathrm{Ca}$ requires the presence of an aqueous solution; i.e., the $\mathrm{H}_{2} \mathrm{O}$ steam must condense to be able to dissolve the released $\mathrm{Ca}$ and drain it away from the reaction zone. The presence of calcite in some Allende CAIs (Fig. 12c) suggests that $\mathrm{P}_{\mathrm{CO} 2}$ in the gaseous phase was high enough to produce carbonic acid upon steam condensation, making the $\mathrm{HCO}_{3}{ }^{-}$main anion of the aqueous solution. Similar reaction equations can be written for reactions 4-20. 
The results of modeling are shown in Figs. 16, 17, 18, and 19.

The reactions involving alteration of melilite (R5, R11, R12) by addition of either gaseous $\mathrm{H}_{4} \mathrm{SiO}_{4}$ or aqueous $\mathrm{SiO}_{2}$ (Fig. 16) can proceed forward at any temperature and pressure because the required $\mathrm{H}_{4} \mathrm{SiO}_{4}$ fugacities in steam and activities of $\mathrm{SiO}_{2}$ in aqueous solution are either much lower than or comparable with the solubility of $\mathrm{SiO}_{2}$ in the steam or the aqueous solution formed by its condensation.

Of special value here are the reactions describing possible alteration of nepheline to analcime by addition of $\mathrm{SiO}_{2}$ and $\pm \mathrm{H}_{2} \mathrm{O}$ :

$$
\begin{aligned}
\mathrm{R} 27 a q & : \mathrm{NaAlSiO}_{4(\mathrm{~s})}+\mathrm{SiO}_{2(\mathrm{aq})}+\mathrm{H}_{2} \mathrm{O}_{(\mathrm{aq})} \\
& =\mathrm{NaAlSi}_{2} \mathrm{O}_{6} \times \mathrm{H}_{2} \mathrm{O}_{(\mathrm{s})} \\
\lg \mathrm{K}_{27 a q} & =-\lg \left[\mathrm{SiO}_{2}\right] \\
\mathrm{R} 27 g & : \mathrm{NaAlSiO}_{4(\mathrm{~s})}+\mathrm{H}_{4} \mathrm{SiO}_{4(\mathrm{~g})} \\
& =\mathrm{NaAlSi}_{2} \mathrm{O}_{6} \times \mathrm{H}_{2} \mathrm{O}_{(\mathrm{s})}+\mathrm{H}_{2} \mathrm{O}_{(\mathrm{g})} \\
\lg \mathrm{K}_{27 g} & =\operatorname{lgP}_{\mathrm{H} 2 \mathrm{O}}-\operatorname{lgP}_{\mathrm{H} 4 \mathrm{SiO} 4}=-\lg \mathrm{X}_{\mathrm{H} 4 \mathrm{SiO} 4}
\end{aligned}
$$

Experimental studies at $\mathrm{T}-\mathrm{P}_{\mathrm{H} 2 \mathrm{O}}$ conditions identical to considered here (Wilkin and Barnes 1998) showed that analcime is a stable phase, which can be dissolved or replaced by other phases if activities of $\mathrm{SiO}_{2}$ and cations in the aqueous solution change. Therefore, the lack of analcime in the $\mathrm{CV}$ chondrites effectively places an upper limit on the $\mathrm{H}_{4} \mathrm{SiO}_{4}$ fugacity in the steam (Fig. 16, top panel) and $\mathrm{SiO}_{2}$ activity in aqueous solution (Fig. 16, bottom panel) implying that during CAIs' alteration, neither steam nor aqueous solution was $\mathrm{SiO}_{2}$-saturated. $\mathrm{Be}$ cause the upper limit of aqueous $\mathrm{SiO}_{2}$ activity is 3-6 orders of magnitude higher than that in the aqueous solution made by in situ condensation of steam (Fig. 16, bottom panel), a solution with a higher concentration of $\mathrm{SiO}_{2}$, tentatively labeled as "external" aqueous solution, can be involved in CAI's alteration. Such a solution must come to a CAI from outside (matrix?) as a liquid (Krot et al. 2001b; Ganino and Libourel 2017). In principle, it may be the same aqueous solution, which feeds the steam. Concentrations and ratios of solutes in such two solutions communicating with each other via steam would differ substantially due to different partition coefficients for different solutes. Another important chemical difference between these two solutions is that the "condensed steam" solution is expected to be free of $\mathrm{Fe}, \mathrm{Ca}$, and other elements, which are not efficiently transported by the steam. The lower limit on the $\mathrm{H}_{4} \mathrm{SiO}_{4}$ fugacity and $\mathrm{SiO}_{2}$ activity is set by reactions $\mathrm{R} 11$ and R5, respectively, which are widespread in the Allende coarse-grained igneous CAIs.
The phase equilibria involving loss or gain of $\mathrm{CO}_{2}$ :

$$
\begin{aligned}
& \text { R28 : } \underset{\text { calcite }}{3 \mathrm{CaCO}_{3(\mathrm{~s})}}+\underset{\text { wollastonite }}{2 \mathrm{CaSiO}_{3(\mathrm{~s})}}=\underset{\mathrm{Ca}_{5} \mathrm{Si}_{2} \mathrm{O}_{7}\left(\mathrm{CO}_{3}\right)_{2(\mathrm{~s})}}{\text { tilleyite }}+\mathrm{CO}_{2(\mathrm{~g})} \\
& \text { R29: } \underset{\text { tilleyite }}{\mathrm{Ca}_{5} \mathrm{Si}_{2} \mathrm{O}_{7}\left(\mathrm{CO}_{3}\right)_{2(\mathrm{~s})}}=\underset{\text { spurrite }}{\mathrm{Ca}_{5} \mathrm{Si}_{2} \mathrm{O}_{8}\left(\mathrm{CO}_{3}\right)_{(\mathrm{s})}}+\mathrm{CO}_{2(\mathrm{~g})} \\
& \mathrm{R} 30 a q: \mathrm{CaCO}_{3(\mathrm{~s})}+\mathrm{SiO}_{2(\mathrm{aq})} \\
& =\mathrm{CaSiO}_{3(\mathrm{~s})}+\mathrm{CO}_{2(\mathrm{~g})} \\
& \mathrm{R} 30 \mathrm{~g}: \mathrm{CaCO}_{3(\mathrm{~s})}+\mathrm{H}_{4} \mathrm{SiO}_{4(\mathrm{~g})} \\
& =\mathrm{CaSiO}_{3(\mathrm{~s})}+\mathrm{CO}_{2(\mathrm{~g})}+2 \mathrm{H}_{2} \mathrm{O}_{(\mathrm{g})}
\end{aligned}
$$

require rather low mole fraction of $\mathrm{CO}_{2}$ in the steam (Fig. 17), which seems to be reasonable for a Cbearing system such as carbonaceous chondrites. The occurrence of wollastonite, tylleyite, and calcite within the same CAI (All-2; Fig. 12a-c) gives a reasonable estimate of mole fractions $\left(\mathrm{X}_{\mathrm{CO} 2}\right)$ and partial pressures $\left(\mathrm{X}_{\mathrm{CO} 2} \times \mathrm{P}_{\mathrm{H} 2 \mathrm{O} \text {,sat }}\right)$ of $\mathrm{CO}_{2}$ in the steam as well as activities of the $\mathrm{HCO}_{3}{ }^{-}$ion in aqueous solution. At such conditions, the observed replacement of melilite by grossular + monticellite + forsterite (R16) can readily proceed, providing the released $\mathrm{CaO}$ reacts with $\mathrm{CO}_{2}$ to form calcite, regardless of whether an aqueous solution saturated in calcite is present or not.

Many alteration reactions require the addition of $\mathrm{CO}_{2} \pm \mathrm{SiO}_{2}$ accompanied by removal of $\mathrm{Ca} \pm \mathrm{SiO}_{2}$. While both $\mathrm{CO}_{2}$ and $\mathrm{SiO}_{2}$ can be added or removed in either steam (bottom panels) or aqueous solution (top panels), the very low solubility of $\mathrm{Ca}$ in steam requires the presence of an aqueous solution, which would absorb the released $\mathrm{Ca}$ as either dissolved $\mathrm{Ca}$ bicarbonate, $\mathrm{Ca}^{2+}+$ $2 \mathrm{HCO}_{3}{ }^{-}$(Fig. 18) or calcite (Fig. 17). If $\mathrm{SiO}_{2}$ is delivered in the steam, the latter must condense to form an aqueous solution, initially $\mathrm{Ca}$-free, before alteration reactions can proceed. In such a case, the amount of aqueous solution is expected to be rather small, with its Ca absorption capacity being limited. The $\mathrm{Ca}$ concntration in the aqueous solution will affect the sequence of alteration reactions, with the alteration of gelenitic melilite to anorthite being the most sensitive to the Ca buildup. If such aqueous solution was not effectively drained before becoming calcite saturated, one would expect to see widespread calcite associated with altered silicates. While calcite does present at least in some altered Allende CAIs, it tends to occur in nodules hinting for effective removal of $\mathrm{Ca}^{2+}$ and $\mathrm{HCO}_{3}{ }^{-}$with drained solution, which can accumulate in cavities and fill them with calcite and other $\mathrm{CO}_{2}$-bearing minerals upon evaporation of water to form nodules. 
The formation of nepheline and sodalite (Fig. 19) requires an addition of $\mathrm{Na}$ and $\mathrm{Cl}$ and removal of $\mathrm{Ca}$ (R19, R20) and addition or removal of $\mathrm{SiO}_{2}$ (R31, R32):

$$
\begin{aligned}
\mathrm{R} 31 \mathrm{aq}: & 2 \mathrm{Ca}_{2} \mathrm{Al}_{2} \mathrm{SiO}_{7(\mathrm{~s})}+3 \mathrm{SiO}_{2(\mathrm{aq})}+2 \mathrm{Na}^{+}{ }_{(\mathrm{aq})} \\
= & \mathrm{Ca}_{3} \mathrm{Al}_{2} \mathrm{Si}_{3} \mathrm{O}_{12(\mathrm{~s})}+2 \mathrm{NaAlSiO}_{4(\mathrm{~s})} \\
& +\mathrm{Ca}^{2+}{ }_{(\mathrm{aq})}
\end{aligned}
$$
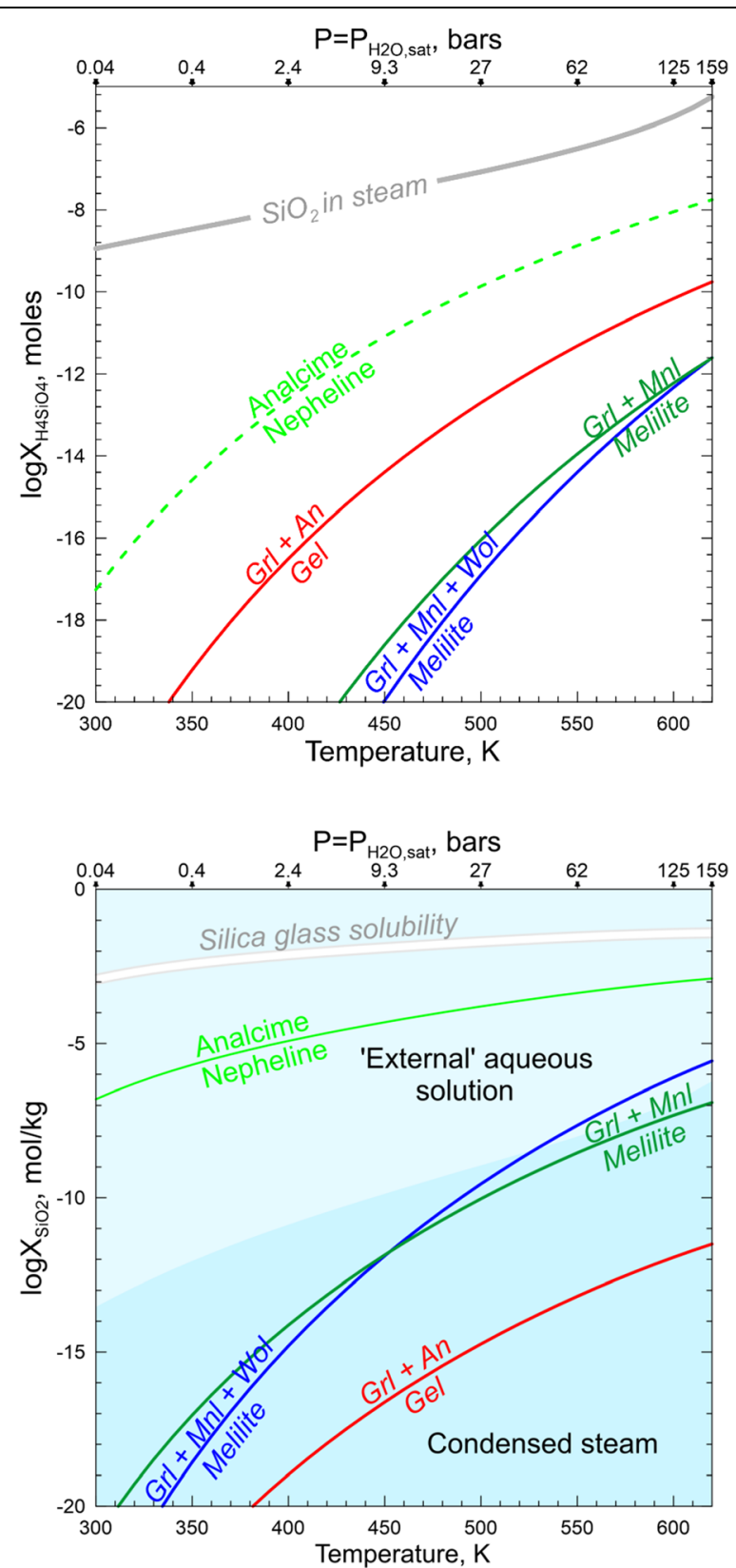

Fig. 16 Phase boundaries of reactions involving either aqueous (top panel) or gaseous (lower panel) silica. The lack of analcime among alteration products places an upper limit on $\mathrm{X}_{\mathrm{H} 4 \mathrm{SiO} 4}$ or $\mathrm{X}_{\mathrm{SiO} 2}$ in steam and aqueous solution, respectively. In the lower panel, the "condensed steam" field designates an aqueous solution formed by in situ condensation of steam as opposed to the "external" aqueous solution, which comes to a CAl from outside (matrix?) as a liquid 

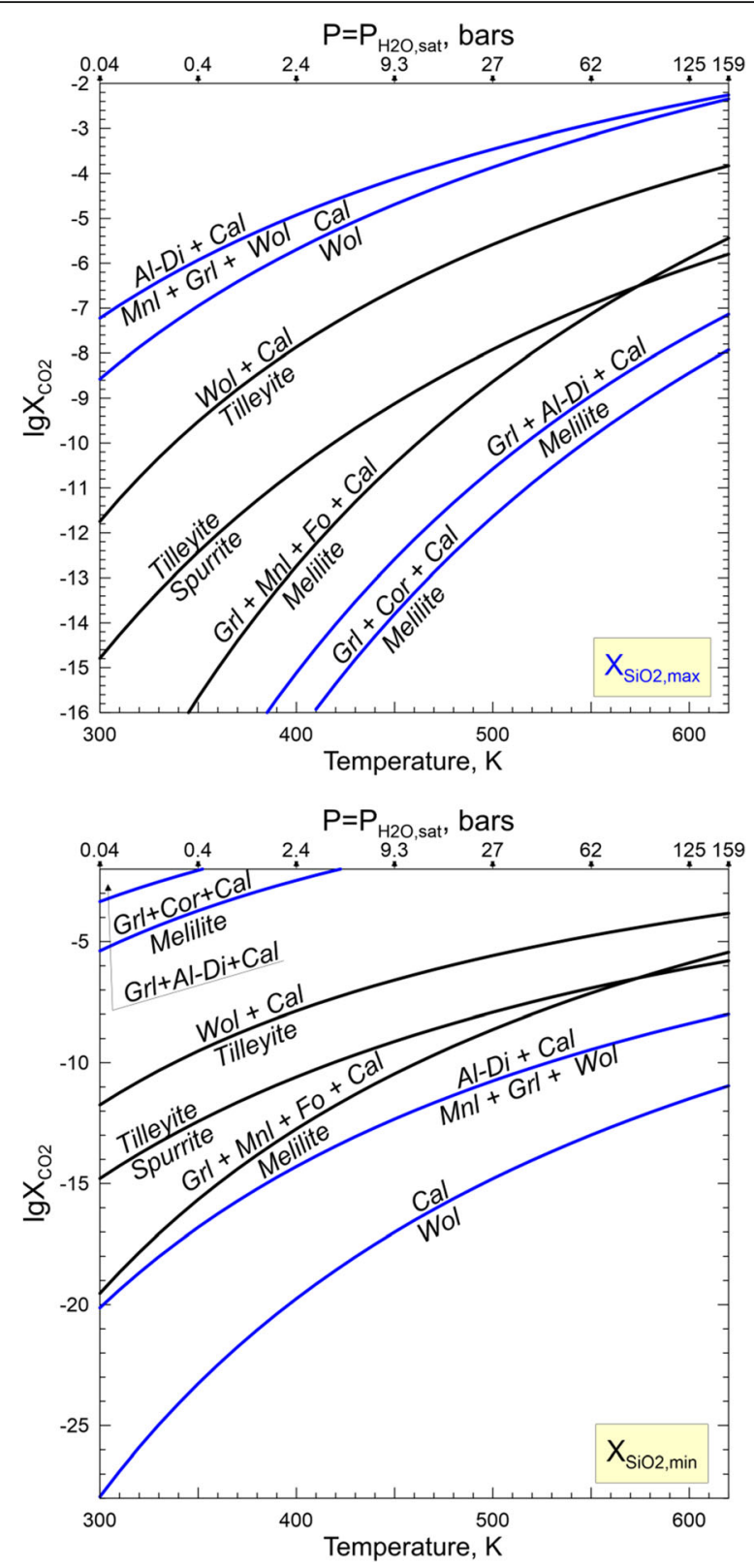

Fig. 17 Phase boundaries of reactions involving $\mathrm{CO}_{2}$ (R16, R28, R29 - black lines) and aqueous $\mathrm{SiO}_{2}(\mathrm{R} 6, \mathrm{R} 7, \mathrm{R} 14, \mathrm{R} 30$ - blue lines) at maximal ( $\mathrm{X}_{\mathrm{SiO} 2 \text {,max }}$ defined by R27 - top panel) and minimal $\left(\mathrm{X}_{\mathrm{SiO} \text {,min }}\right.$ defined by $\mathrm{R} 5$ - bottom panel) values of $\mathrm{SiO}_{2}$ activity

$$
\begin{aligned}
\mathrm{R} 32 a q: & 2 \mathrm{CaAl}_{2} \mathrm{Si}_{2} \mathrm{O}_{8(\mathrm{~s})}+2 \mathrm{Na}^{+}{ }_{(\mathrm{aq})}+2 \mathrm{CO}_{2(\mathrm{~g})} \\
& +\mathrm{H}_{2} \mathrm{O}_{(\mathrm{aq})} \\
= & 2 \mathrm{NaAlSiO}_{4(\mathrm{~s})}+\mathrm{Al}_{2} \mathrm{O}_{3(\mathrm{~s})}+2 \mathrm{Ca}^{2+}{ }_{(\mathrm{aq})} \\
& +2 \mathrm{HCO}_{3}{ }_{(\mathrm{aq})}+2 \mathrm{SiO}_{2(\mathrm{aq})}
\end{aligned}
$$

$\mathrm{Na}, \mathrm{Cl}$, and $\mathrm{SiO}_{2}$ can be transported by either steam or aqueous solution, but the necessity to remove $\mathrm{Ca}$ requires the presence of an aqueous solution. As discussed above, the latter can be formed either by steam condensation or arrive from the matrix. The substitution of anorthite by sodalite at higher temperatures requires a solution with rather low $\mathrm{Na}$ (and $\mathrm{Cl}$ ) concentrations that can be formed by the steam condensation. At lower temperatures, an "external" aqueous solution with higher $\mathrm{Na}$ and $\mathrm{Cl}$ concentration is required. Other reactions can proceed only in the presence of an "external" aqueous solution with high concentrations of $\mathrm{Na}$ and $\mathrm{Cl}$. It is interesting to note that the presence of widespread $\mathrm{Cl}$-bearing and $\mathrm{Na}$-free wadalite in many altered Type B CAIs points to the decoupling of $\mathrm{Na}$ and $\mathrm{Cl}$ during at least the 
Knot et al. Progress in Earth and Planetary Science

(2021) 8:61

Page 29 of 37
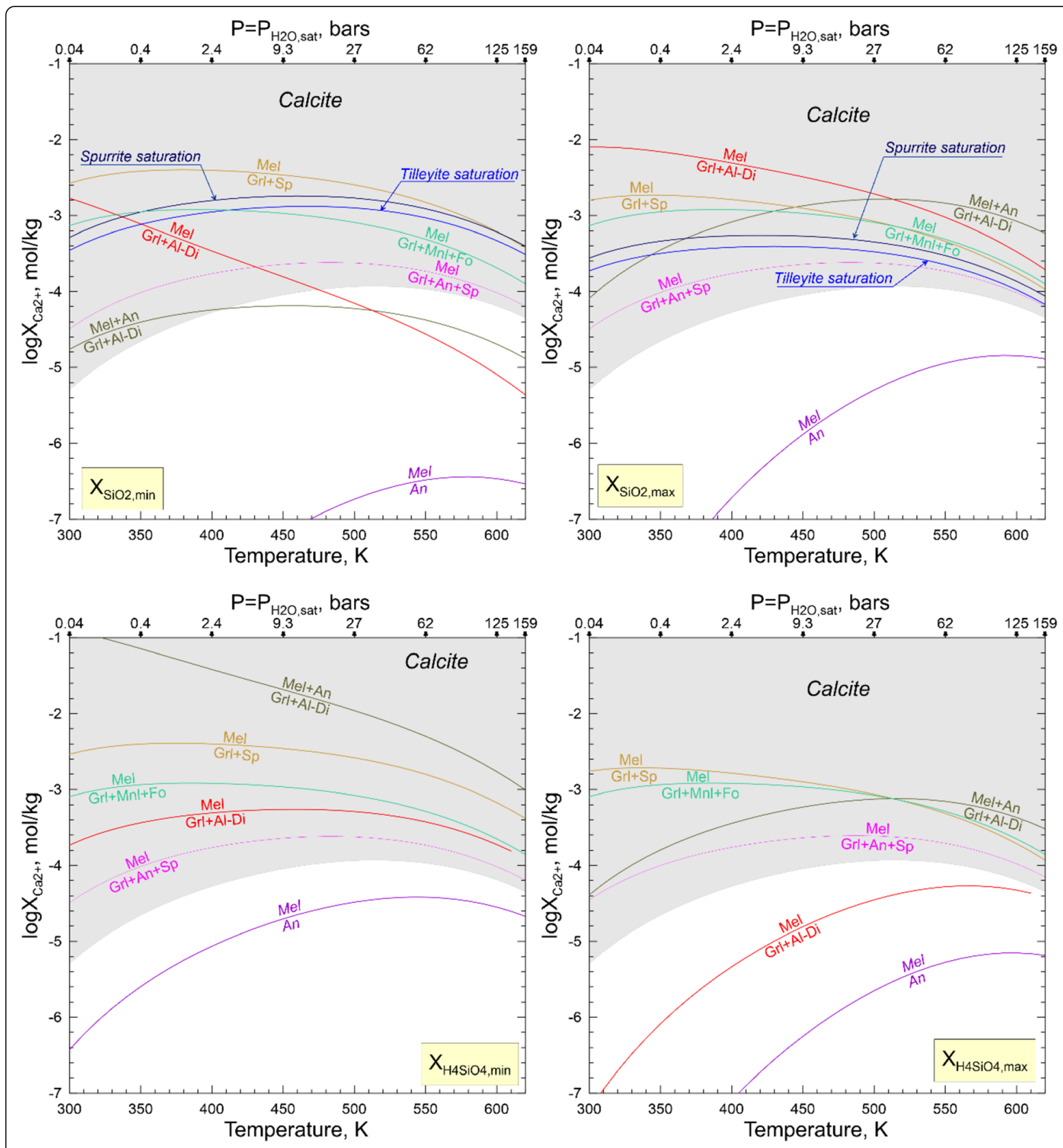

Fig. 18 Phase boundaries of reactions involving addition of either aqueous $\mathrm{SiO}_{2}$ or gaseous $\mathrm{H}_{4} \mathrm{SiO}_{4}$ and removal of $\mathrm{Ca}$ in the form of dissolved Ca bicarbonate, $\mathrm{Ca}^{2+}+2 \mathrm{HCO}_{3}{ }^{-}$, at $\mathrm{X}_{\mathrm{CO} 2}$ defined by R28 (wollastonite-calcite-tilleyite equilibrium) and different values of $\mathrm{SiO}_{2}$ activity and $\mathrm{H}_{4} \mathrm{SiO}_{4}$ fugacity defined by reactions R5 and R11 (Fig. 19). In each plot, the labeled curves of different colors separate the "primary" (above the curves) and "secondary" (below the curves) assemblages which correspond to the reactants and products of each reaction, respectively. The gray calcite saturation line separates two different phase assemblages containing silicates + calcite + aqueous solution above the line and silicates + aqueous solution below it. The tilleyite and spurrite saturation curves show conditions when a mineral starts to crystallize from an aqueous solution according to a reaction $\mathrm{Ca}^{2+}+\mathrm{HCO}_{3}^{-}+\mathrm{SiO}_{2} \rightarrow x \mathrm{CaO} \cdot y \mathrm{SiO}_{2} \cdot \mathrm{ZCO}_{2}+\mathrm{CO}_{2(\mathrm{~g})}+\mathrm{H}_{2} \mathrm{O}_{(\mathrm{g})}$ 


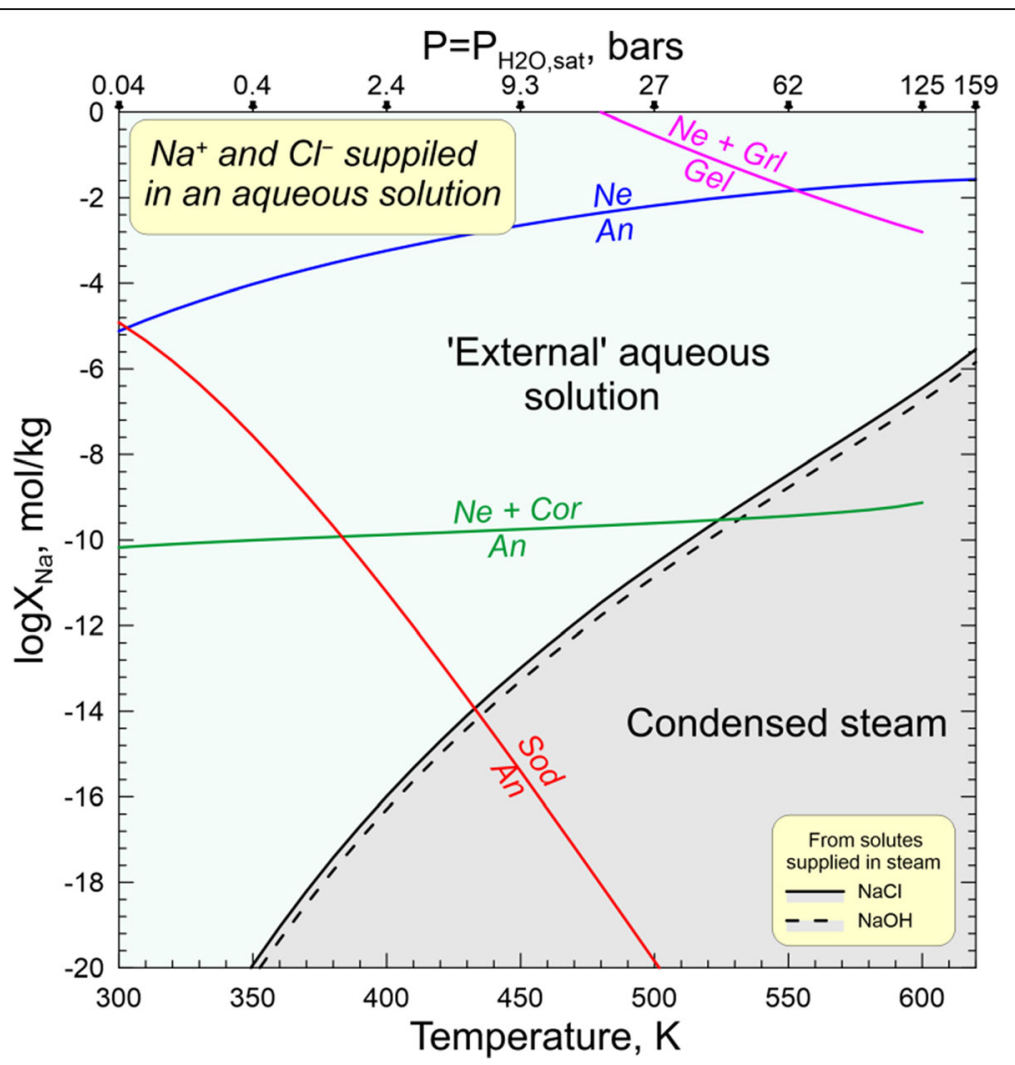

Fig. 19 Phase boundaries of reactions R19, R20, R31 and R32 involving addition of $\mathrm{Na}^{+}$and removal of $\mathrm{Ca}^{2+}$ at the $\mathrm{X}_{\mathrm{CO} 2}$ defined by R28, lowest $X_{\mathrm{Ca} 2+}$ defined by R4 (melilite-anorthite equilibrium - top left panel of Fig. 20). The activity of aqueous $\mathrm{SiO}_{2}$ in reactions R31 and R32 is set at the upper limit of $\mathrm{X}_{\mathrm{SiO} 2}$ defined by R27. The "condensed steam" field designates an aqueous solution formed by in situ condensation of steam as opposed to the "external" aqueous solution, which comes to a CAl from outside (matrix?) as a liquid

early stages of aqueous alteration. In this case, the $\mathrm{Cl}$ could be supplied by the steam containing $\mathrm{HCl}$ and $\mathrm{NH}_{4} \mathrm{Cl}$ but neither $\mathrm{NaCl}$ nor $\mathrm{NaOH}$.

\subsection{Oxygen isotopic composition of metasomatic fluid on the $\mathrm{CV}$ chondrites parent asteroid}

Most secondary minerals measured for oxygen isotopic composition in the Allende Type B and FoB CAIs (TS-34, TS-31, AJEF, TS-21, and All-2) replace primary melilite and to a lesser degree anorthite. These primary minerals are typically ${ }^{16} \mathrm{O}$-depleted relative to the minerals largely unaffected by secondary alteration - spinel, hibonite, forsterite, and most Al,Ti-diopside grains (very Ti-rich fassaite in TS-34 is the only exception): $\Delta^{17} \mathrm{O}$ range from -5 to $-1 \%$ vs. $\sim-25$ to $-20 \%$, respectively. Larger variations in $\Delta^{17} \mathrm{O}$ (up to $-10 \%$ ) are observed in anorthite of TS-34 (Fig. 13a, b). In TS-31, AJEF, TS-21, and All-2, secondary minerals plot along massdependent fractionation line with $\Delta^{17} \mathrm{O}$ of $\sim-3 \pm 2 \%$ and show a much smaller range of $\delta^{18} \mathrm{O}$, from $\sim 0$ to $\sim+10 \%$, compared to the previously published data, from $\sim-15$ to + $20 \%$ (Fig. 13b, g) acquired without the use of proper mineral standards. Because metasomatic alteration of Allende CAIs occurred in the presence of aqueous solution/fluid and some minerals directly precipitated from it, we infer that $\Delta^{17} \mathrm{O}$ of the secondary minerals recorded $\Delta^{17} \mathrm{O}$ of the fluid. This conclusion is consistent with similar $\Delta^{17} \mathrm{O}(-1.5 \pm 1 \%)$ of aqueously formed fayalite and magnetite in the oxidized CV3.1 chondrite Kaba (Doyle et al. 2015).

Assuming that oxygen-isotope composition of the fluid was constant and that secondary minerals were in isotopic equilibrium with it, $\delta^{18} \mathrm{O}$ of the minerals with known water-mineral isotope fractionation can be used to constrain the temperature of alteration (Zheng 1991, 1993). Because O-isotope fractionation between mineral and water decreases with temperature increase (Fig. 20), the relatively small range of $\delta^{18} \mathrm{O}$ of the secondary minerals, $\sim 10 \%$, which is much smaller than those between aqueously formed magnetite and carbonates in $\mathrm{CI}, \mathrm{CM}$, and $\mathrm{CR}$ chondrites (up to $\sim 30 \%$; see Fig. 16 in Krot et al. 2015), is consistent with a relatively high temperature of the $\mathrm{CV}$ metasomatic alteration, $>200^{\circ} \mathrm{C}$, compared to those of CIs, CRs, and CMs, $<100^{\circ} \mathrm{C}$ (Krot et al. 2015 and references therein). This is also consistent with a small range of $\delta^{18} \mathrm{O}, \sim 5 \%$, between aqueously formed magnetite and pure fayalite in the least metamorphosed CV chondrite Kaba, which 


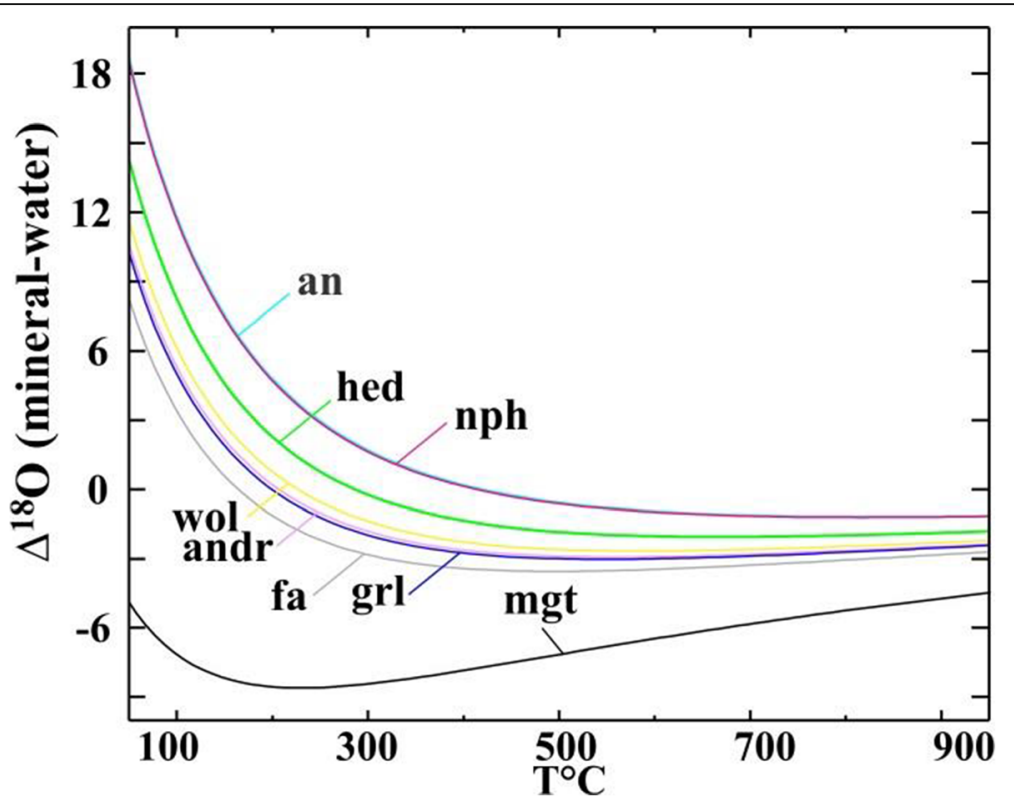

Fig. 20 Calculated oxygen-isotope fractionations for anhydrous silicate-water and magnetite-water as a function of temperature (Zheng 1991, 1993)

apparently experienced lower temperature metasomatic alteration than Allende (Krot et al. 2018). We note, however, that our petrographic observations indicate that the chemical composition of the Allende fluid evolved with time and alteration was probably multistage (see above). Therefore it seems highly unlikely that the O-isotope composition of the fluid remained constant. As a result, the entire range of $\delta^{18} \mathrm{O}$ among secondary minerals measured, 10\%o, cannot be used to constrain the temperature of alteration of Allende CAIs: data for Oisotope compositions of secondary minerals that appear to have formed contemporaneously within an individual CAI could be more appropriate. Unfortunately, only a limited number of secondary minerals within individual CAIs have been measured with matrix-matched standards by now (Fig. 13c), and no special attention has been to whether the secondary minerals analyzed are cogenetic. To illustrate the latter point, in Fig. 21 a and b, we plotted O-isotope compositions of secondary minerals in two Allende CAIs, TS-31 and All-2. Although the observed range of $\delta^{18} \mathrm{O}$ between grossular and wollastonite replacing melilite in these inclusions is rather limited, 4-6\%o, the secondary minerals are apparently not in isotopic equilibrium (there are some differences in $\Delta^{17} \mathrm{O}$ ) and may be not cogenetic. Therefore, these data cannot be used for estimating a temperature of metasomatic alteration as well.

Larger ranges of $\Delta^{17} \mathrm{O}$ are observed in secondary grossular and forsterite in the Type C CAIs 100 and 160 (from $\sim-15$ to $\sim-1 \%$ ) and Type B1 CAI TS-34 (from $\sim-10$ to $\sim-1 \%$ o). In contrast to other CAIs measured, grossular and forsterite in these inclusions plot along
CCAM line (Fig. 21c, d). The similar ranges of $\Delta^{17} \mathrm{O}$ and positions on a three-isotope oxygen diagram are observed for primary anorthite in these CAIs. Melilite is the most ${ }^{16} \mathrm{O}$-depleted primary phase in these inclusions $\left(\Delta^{17} \mathrm{O} \sim-5\right.$ to $\sim-1 \%$ ). We suggest that grossular and forsterite in TS-34, 100, and 160 could have largely inherited oxygen isotopic compositions of the primary melilite and anorthite which experienced incomplete $\mathrm{O}$ isotope exchange with the fluid phase (see Role of aqueous fluid-rock interaction in $\mathrm{O}$-isotope exchange in primary CAI minerals). In the case of Type C CAIs, this might be due to alteration under relatively dry conditions (see Alteration of lacy melilite).

\subsection{Role of aqueous fluid-rock interaction in 0-isotope exchange in primary CAI minerals}

Oxygen isotopic composition of the $\mathrm{CV}$ aqueous fluid inferred from secondary minerals $\left(\Delta^{17} \mathrm{O} \sim-3 \pm 2 \%\right.$ ) is very similar to the most ${ }^{16} \mathrm{O}$-depleted compositions of primary melilite, anorthite, and very $\mathrm{Ti}$-rich fassaite in the isotopically heterogeneous coarse-grained igneous CAIs from Allende studied (Fig. 13). Hibonite, spinel, forsterite, and most fassaite grains in these CAIs have ${ }^{16} \mathrm{O}$-rich, solar-like compositions. A similar O-isotope heterogeneity is observed in all types of igneous CAIs (CTA, B, FoB, and C) from metamorphosed CV chondrites, irrespective of mineral crystallization sequence and evaporation history (Fig. 13c, e, f). Because the vast majority of refractory inclusions in unmetamorphosed carbonaceous chondrites (CM2, CR2, CH3.0, CO3.0, and Acfer 094) have uniform solar-like oxygen isotopic compositions $\left(\Delta^{17} \mathrm{O} \sim-24 \%\right.$; Yurimoto et al. 2008; Makide 

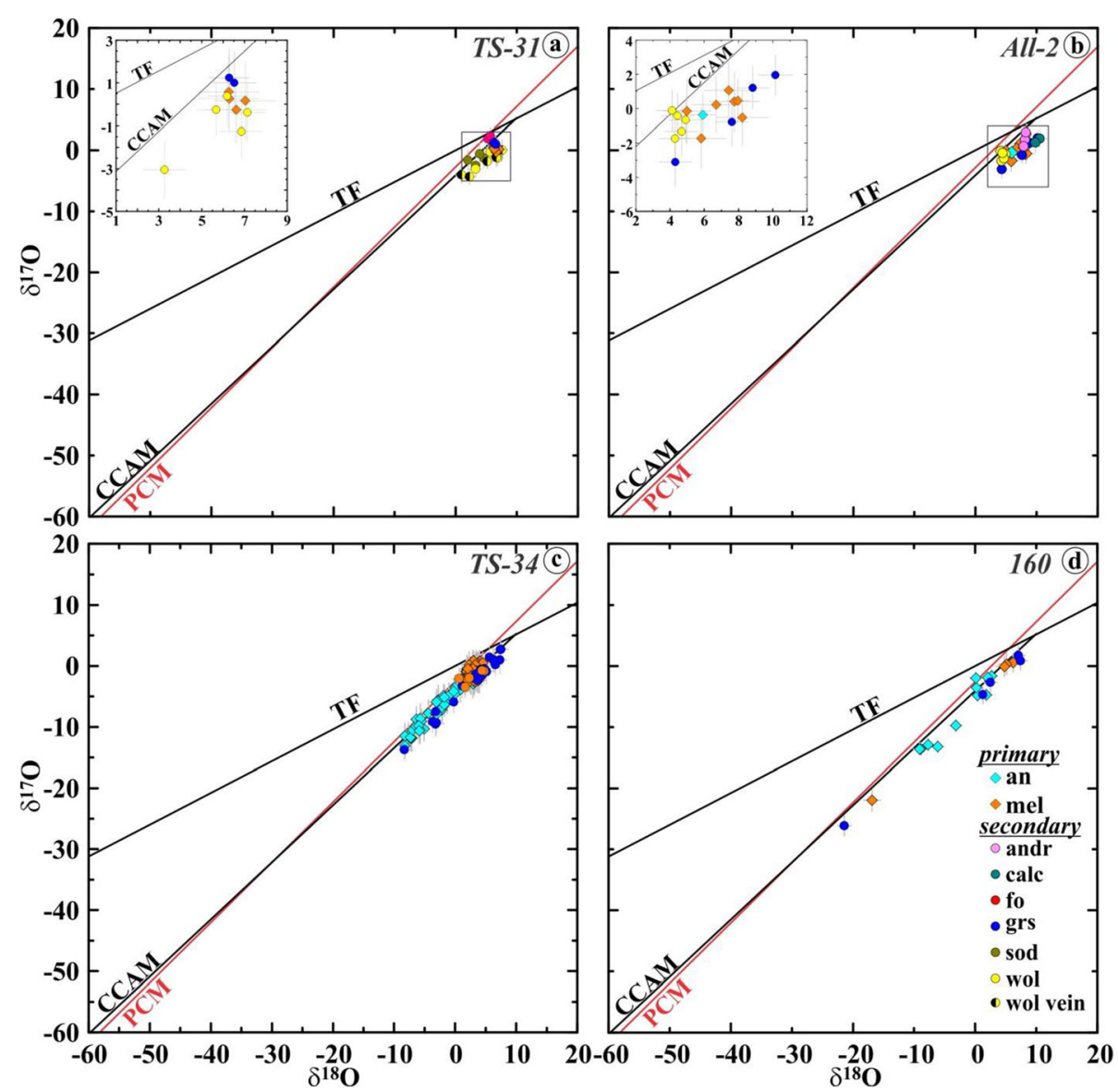

Fig. 21 Three-isotope oxygen diagrams on primary melilite and anorthite, and secondary andradite, calcite, grossular, sodalite, and wollastonite in the Allende CAls TS-31 (B2), All-2 (FoB), TS-34 (B1), and 160 (C). Grossular and wollastonite (yellow circles) replace melilite and appear to have formed contemporaneously. Andradite, calcite, and wollastonite in veins (black-and-yellow circles) crosscutting the grossular \pm wollastonite-bearing assemblages precipitated directly from aqueous solutions. Primary melilite and anorthite are ${ }^{16} \mathrm{O}$-depleted relative to spinel, Al,Ti-diopside (except TS-34), and forsterite; melilite is more ${ }^{16} \mathrm{O}$-depleted than anorthite. Secondary minerals have similar compositions to those of anorthite and melilite. In TS-31 and All-2, secondary minerals plot along mass-dependent fractionation line slightly below the TF line $\left(\Delta^{17} \mathrm{O} \sim-3 \% 0\right)$. Insets in "a" and "b" show O-isotope compositions of grossular and wollastonite that appear to have formed contemporaneously by replacing primary melilite; there is a small range of $\delta^{18} \mathrm{O}$ between these secondary minerals, 4 and 6\% in TS-31 and All-2, respectively. In TS-34 and 160, secondary grossular together with primary melilite and anorthite plot along CCAM line

et al. 2009; Ushikubo et al. 2017; Krot et al. 2020b), these observations may indicate that melilite and anorthite in Allende CAIs, experienced oxygen isotopic exchange with an aqueous fluid on the $\mathrm{CV}$ parent asteroid, whereas hibonite, spinel, Al,Ti-diopside, and forsterite retained their original compositions. Since ${ }^{16} \mathrm{O}$-rich and ${ }^{16} \mathrm{O}$-depleted gaseous reservoirs appear to have coexisted in the early solar nebula (e.g., Itoh and Yurimoto 2003; Simon et al. 2011, 2016, 2019; Krot et al. 2020b) and coarse-grained igneous CAIs experienced multiple melting events (Krot 2019 and references therein), this interpretation does not preclude O-isotope exchange during gas-melt interaction in the solar nebula of variable isotopic composition (e.g., Yurimoto et al. 1998; Kawasaki et al. 2018). To understand potential role of the $\mathrm{CV}$ aqueous fluid in $\mathrm{O}$-isotope exchange, experimental data on oxygen self-diffusion in CAI minerals under high temperature and wet conditions are required.

\subsection{Aluminum-magnesium isotope systematics of secondary minerals in the Allende CAls}

Aluminum-magnesium isotope systematics of secondary minerals in the Allende CAIs is often used as evidence for a prolonged duration of the alteration that may have started in the solar nebula shortly after the formation of CAIs, continued during chondrule formation, and on the CV chondrite parent body (e.g., Ushikubo et al. 2007; Fagan et al. 2007). This interpretation is based on the occasional presence of resolvable ${ }^{26} \mathrm{Mg}^{*}$ in some secondary grossular and anorthite grains and its common absence in the vast majority of secondary minerals measured. 
To test this interpretation, we measured $\mathrm{Al}-\mathrm{Mg}$ isotope systematics in grossular grains replacing melilite of different chemical compositions (Fig. 14). Grossular in the nearly monomineralic veins crosscutting gehlenitic melilite mantle in the Type B1 CAI TS-34 has a similar ${ }^{27} \mathrm{Al} /{ }^{24} \mathrm{Mg}$ ratio to those of the host melilite (6.5-9 vs. 5.8-10; up to 20 in melilite); all grossular grains measured show resolvable ${ }^{26} \mathrm{Mg}^{*}$. In contrast, grossular associating with monticellite, forsterite, and Al-diopside, and replacing åkermanitic melilite $\left({ }^{27} \mathrm{Al} /{ }^{24} \mathrm{Mg}=1.3-1.9\right)$ in TS-34 and several other Type Bs has significantly higher ${ }^{27} \mathrm{Al} /{ }^{24} \mathrm{Mg}$ (30-100) ratio and lacks resolvable ${ }^{26} \mathrm{Mg}^{*}$ $(0.2 \pm 2 \%$ for $T S-34)$; the latter is indistinguishable from an average ${ }^{26} \mathrm{Mg}^{*}$ in the åkermanitic melilite $(0.7 \pm 0.4 \%$ o). The high ${ }^{27} \mathrm{Al} /{ }^{24} \mathrm{Mg}$ ratio in these grossulars is probably due to $\mathrm{Al}-\mathrm{Mg}$ fractionation between the grossular and other cogenetic secondary minerals: most magnesium is partioned into monticellite, forsterite, and $\mathrm{Al}$-diopside. The upper limit on timing of this fractionation, and therefore, the timing of the metasomatic alteration is $\sim 3.5$ Ma. Based on these observations, we conclude that ${ }^{26} \mathrm{Mg}^{*}$ in grossular replacing both gehlenitic and åkermanitic melilite was largely inherited from melilite after nearly complete decay of ${ }^{26} \mathrm{Al},>3.5 \mathrm{Ma}$ after crystallization of primary minerals of their host CAIs. The late-stage formation of grossular with and without resolvable ${ }^{26} \mathrm{Mg}^{*}$ is consistent with their similar O-isotope compositions. It is also consistent with ${ }^{53} \mathrm{Mn}-{ }^{53} \mathrm{Cr}$ ages of the metasomatically formed fayalite and kirschsteinite in the CV3 chondrites Asuka-881317 (4. $2_{-0.7}^{+0.8} \mathrm{Ma}$, Doyle et al. 2015) and Vigarano $\left(3.2_{-0.7}^{+0.8} \mathrm{Ma}\right.$, MacPherson et al. 2017), respectively.

Ushikubo et al. (2007) reported ${ }^{26} \mathrm{Mg}^{*}$ in coarse-grained ragged anorthite surrounded by secondary grossular and monticellite in the Allende Type B2 CAI 2 that corresponds to $\left({ }^{26} \mathrm{Al} /{ }^{27} \mathrm{Al}\right)_{0}$ of $\sim(1.2 \pm 0.2) \times 10^{-5}$. No resolvable ${ }^{26} \mathrm{Mg}^{*}$ was found in the grossular: $\left({ }^{26} \mathrm{Al} /{ }^{27} \mathrm{Al}\right)_{0}<4.4 \times 10^{-7}$. Largely based on the unusual morphology of the anorthite grains and their close association with grossular, Ushikubo et al. concluded that the anorthite is secondary, suggesting that alteration started 1.5 Ma after crystallization of CAIs with the canonical $\left({ }^{26} \mathrm{Al} /{ }^{27} \mathrm{Al}\right)_{0}$ and lasted for several Ma. Dr. T. Ushikubo kindly provided to us a polished section of this CAI. Our preliminary petrographic and mineralogical observations indicate that the ragged anorthite is in fact the primary igneous phase. The supporting arguments include: (i) the tripple junctions between ragged anorthite, Al,Ti-diopside, and unaltered åkermanitic melilite suggesting co-crystallization of these minerals; (ii) the presence of unaltered igneous inclusions of melilite and $\mathrm{Al}, \mathrm{Ti}$-diopside in some anorthite grains; (iii) the presence of secondary Na-rich melilite corroding edges of anorthite grains, as commonly observed in igneous anorthite in the
Allende type Bs and FoBs (Fig. 7). We conclude that (1) secondary grossular, wollastonite, monticellite, forsterite, and Na-melilite around anorthite grains in the CAI 2 replace åkermanitic melilite, and are not genetically related to anorthite; and (2) the low initial ${ }^{26} \mathrm{Al} /{ }^{27} \mathrm{Al}$ ratio in ragged anorthite (Ushikubo et al. 2007) reflects the disturbance of its $\mathrm{Al}-\mathrm{Mg}$ systematics during thermal metamorphism as often observed in anorthite of many Allende igneous CAIs (e.g., Kita et al. 2013; MacPherson et al. 2017). As a result, Al-Mg systematics of ragged anorthite in the Allende CAI 2 cannot be used for dating the CV metasomatic alteration.

\section{Conclusions}

1. All major types of coarse-grained igneous CAIs (CTA, B1, B2, FoB, and C) from the oxidized CV3 chondrite Allende experienced metasomatic alteration. This alteration affected mainly melilite and to a lesser degree anorthite, and resulted in the formation of different secondary minerals, including adrianite, Al-diopside, andradite, anorthite, calcite, celsian, clintonite, corundum, dmisteinbergite, ferroan olivine, ferroan monticellite, ferroan $\mathrm{Al}-$ diopside, forsterite, grossular, heazlewoodite, hedenbergite, hutcheonite, kushiroite, margarite, monticellite, Na-melilite, nepheline, pentlandite, pyrrhotite, sodalite, spinel, tilleyite, wadalite, and wollastonite. The secondary mineral assemblages are mainly defined by chemical compositions of the primary melilite replaced:

- Gehlenitic melilite ( $\left(\mathrm{k}_{<35}\right)$ in CTAs, mantles of $\mathrm{B} 1 \mathrm{~s}$, and the outermost regions of other CAI types is mainly replaced by anorthite and grossular; clintonite, corundum, spinel, and $\mathrm{Al}-$ diopside are minor;

- Åkermanitic melilite ( $\left.\AA_{k_{35-90}}\right)$ in Type B2s, FoBs, cores of B1s, and CTA CAI TS-2 is replaced by several mineral assemblages: grossular + monticellite + wollastonite, grossular + monticellite, and grossular + Al-diopside; forsterite, spinel, clintonite, and $\mathrm{Na}$-melilite are minor;

- In type Cs, lacy melilite grains are pseudomorphically replaced by the grossular + forsterite + monticellite and grossular $+\mathrm{Al}-$ diopside mineral assemblages; Na-melilite is minor;

- Primary and secondary anorthites in the peripheral portions of Allende CAIs are replaced by nepheline, sodalite, and ferromagnesian olivine;

- All types of Allende CAIs studied contain voids and cracks filled by andradite, hedenbergite, wollastonite, \pm sodalite, \pm grossular, \pm monticellite, \pm tilleyite, and \pm calcite. 
2. Allende CAIs are surrounded by fine-grained matrix-like rims composed of the secondary lathshaped ferroan olivine and abundant nepheline grains, and by a layer of salite-hedenbergite pyroxenes + andradite + wollastonite.

3. These observations and physico-chemical analysis of the inferred chemical reactions suggest that Allende CAIs experienced an open-system metasomatic alteration in situ in the presence of $\mathrm{CO}_{2}$ and $\mathrm{H}_{2} \mathrm{O}$-bearing fluid on the $\mathrm{CV}$ chondrite parent asteroid at $\sim 150-250{ }^{\circ} \mathrm{C}$. During the alteration, $\mathrm{Si}$, $\mathrm{Na}, \mathrm{Cl}, \mathrm{K}, \mathrm{Fe}, \mathrm{S}$, and $\mathrm{Ni}$ were introduced, whereas $\mathrm{Ca}, \mathrm{Mg}$, and some $\mathrm{Al}$ were lost from the host inclusions; $\mathrm{Ti}$ and $\mathrm{Ba}$ were locally mobilized

4. In the Allende Type B CAIs, grossular associating with monticellite, forsterite, Al-diopside, and wollastonite, and replacing åkermanitic melilite has high ${ }^{27} \mathrm{Al} /{ }^{24} \mathrm{Mg}$ ratios (30-100) and shows no resolvable ${ }^{26} \mathrm{Mg}$. The ${ }^{27} \mathrm{Al} /{ }^{24} \mathrm{Mg}$ ratios and ${ }^{26} \mathrm{Mg}^{*}$ in grossular replacing gehlenitic melilite are similar to those of the host melilite and plot along a regression line with ${ }^{26} \mathrm{Al} /{ }^{27} \mathrm{Al}$ ratio of $\sim 5 \times 10^{-5}$. We conclude that metasomatic alteration occurred after nearly complete decay of ${ }^{26} \mathrm{Al},>3 \mathrm{Ma}$ after crystallization of CAIs with the canonical $\left({ }^{26} \mathrm{Al} /{ }^{27} \mathrm{Al}\right)_{0}$ of $(5.25 \pm 0.02) \times 10^{-5} .{ }^{26} \mathrm{Mg}$ " in grossular was inherited from primary melilite and provides no chronological significance.

5. Oxygen isotopic compositions of most secondary minerals in the Allende Type B CAIs measured in situ with the UH Cameca ims-1280 and matrixmatched standards plot along mass-dependent fractionation line with $\Delta^{17} \mathrm{O}$ of $\sim-3 \pm 2 \%$ with $\delta^{18} \mathrm{O}$ ranging from $\sim 0$ to $\sim 10 \%$. A smaller range of $\delta^{18} \mathrm{O}, \sim 5 \%$, is observed for cogenetic secondary minerals within individual CAIs. We conclude that $\Delta^{17} \mathrm{O}$ of $\sim-3 \pm 2 \%$ corresponds to that of the aqueous fluid on the Allende parent asteroid. A small range of $\delta^{18} \mathrm{O}$ among the secondary minerals is consistent with high-temperature metasomatic alteration of $\sim 150-250{ }^{\circ} \mathrm{C}$.

6. Secondary grossular and forsterite in Type Cs and Type B1 CAI TS-34 show a range of $\Delta{ }^{17} \mathrm{O}$, from -15 to $\sim-1 \pm 2 \%$; and on a three-isotope oxygen diagram plot along CCAM line. The similar variations in O-isotope compositions are observed for primary anorthite in these CAIs; primary melilite is generally more ${ }^{16} \mathrm{O}$-depleted $\left(\Delta^{17} \mathrm{O}\right.$ range from -5 to $\sim-1 \pm 2 \%$ ). Primary spinel, forsterite, and most $\mathrm{Al}$,Ti-diopside grains have ${ }^{16} \mathrm{O}$-rich compositions $\left(\Delta^{17} \mathrm{O} \sim-25 \pm 2 \%\right.$ ). We suggest that oxygen isotopic compositions of grossular and forsterite in these CAIs were largely inherited from melilite and anorthite which may have experienced incomplete O-isotope exchange with a fluid.

\section{Supplementary Information}

The online version contains supplementary material available at https://doi. org/10.1186/s40645-021-00437-4.

\begin{abstract}
Additional file 1: Figure EA1. Backscattered electron images of the Allende Type B2 CAI \#2 characterized by Ushikubo et al. 2007. Primary and secondary minerals are labeled by white and yellow symbols, respectively. The CAI consists of the irregularly-shaped (ragged) melilite (mel), anorthite (an), and Al,Ti-diopside (fas), all poikilitically enclosing spinel (sp) grains. Melilite, anorthite, and Al,Ti-diopside occasionally exhibit triple junctions (see "b"). Most anorthite grains contain exsolutions of submicron silicates. Some anorthite grains contain melt inclusions composed of Al,Ti-diopside and unaltered melilite (see " $\mathrm{C}^{\prime \prime}$ ). Melilite is replaced to various degrees by grossular ( $\mathrm{grl}$ ), forsterite (fo), and monticellite $(\mathrm{mnl})$. Anorthite is almost unaltered: only minor secondary Na-melilite (Na-mel), grossular, and kushiroite (kush) occur at the boundary with melilite. We conclude that ragged anorthite in CAI \#2 is not a secondary phase; it is a primary mineral that crystallized from a CAI melt and largely escaped metasomatic alteration. Therefore, the Al-Mg isotope systematics of this anorthite cannot be used to date the metasomatic alteration.

Table EA1. Representative electron microprobe analyses of secondary minerals in the Allende CAls studied. Table EA2. Oxygen isotopic compositions of primary minerals in the Allende coarse-grained igneous CAls measured by SIMS. Table EA3. Oxygen isotopic compositions of secondary minerals in the Allende coarse-grained igneous CAls measured by SIMS.
\end{abstract}

\section{Acknowledgements}

We thank Dr. S. Simon (University of New Mexico), Dr. G. J. MacPherson (Smithsonian Institution), Dr. D. Wark (University of Melbourne), and Prof. G. J. Wasserburg (California Institute of Technology) for the loan of the Allende CAls' thin sections. We thank Drs. G. Libourel, A. M. Davis, G. J. Wasserburg, I. D. Hutcheon for numerous discussions and useful suggestions. Handling of the manuscript by Associate Editor Dr. Yangting Lin is appreciated. The authors thank two anonymous reviewers for their constructive reviews which help to improve the paper. This work was supported by the National Aeronautics and Space Administration (NASA) Emerging Worlds grant NNX17AE22G (ANK, PI). This paper is dedicated to Professor Ahmed El Goresy who successfully combined mineralogy, petrology, and isotope chemistry in studying extraterrestrial materials.

\section{Authors' contributions}

AK carried out mineralogical and petrographic characterization, and oxygenisotope measurements of refractory inclusions, and drafted the manuscript. KN established analytical protocols of oxygen and Al-Mg isotope measurements, developed O-isotope standards, and carried out Al-Mg isotope measurements of the samples. MP carried out physico-chemical analysis of metasomatic alteration of the Allende refractory inclusions and helped to draft the manuscript. All authors read and approved the final manuscript.

\section{Funding}

Funding for this work was provided by the National Aeronautics and Space Administration (NASA) Emerging Worlds grant NNX17AE22G (AK, Principal Investigator). MIP was partially supported by the NASA Emerging Worlds (80NSSC20K0346) and DOE-NNSA (DE-NA0003904) grants to Stein B. Jacobsen (Harvard University).

\section{Availability of data and materials}

Please contact author (AK) for data requests.

\section{Declaration}

Competing interests

The authors declare that they have no competing interests.

\section{Author details}

'Hawai'i Institute of Geophysics and Planetology, School of Ocean and Earth Science and Technology, University of Hawai'i at Mānoa, Honolulu, HI 96822, USA. ${ }^{2}$ Department of Earth and Planetary Sciences, Harvard University and Harvard-Smithsonian Center for Astrophysics, Cambridge, MA 02138, USA. 
Received: 31 March 2021 Accepted: 23 June 2021

Published online: 04 November 2021

\section{References}

Allen JM, Grossman L, Davis AM, Hutcheon ID (1978) Mineralogy, textures, and mode of formation of a hibonite-bearing Allende inclusion. Proc Lunar Planet Sci Conf 9:1209-1233

Beckett JR, Grossman L (1988) The origin of type C inclusions from carbonaceous chondrites. Earth Planet Sci Lett 89(1):1-14. https://doi.org/10.1016/0012-821 X(88)90028-3

Beckett JR, Simon SB, Stolper E (2000) The partitioning of Na between melilite and liquid: Part II. Applications to type B inclusions from carbonaceous chondrites. Geochim Cosmochim Acta 64:2519-2534

Bodénan J-D, Starkey NA, Russell SS, Wright IP, Franchi IA (2014) An oxygen isotope study of Wark-Lovering rims on Type A CAls in primitive carbonaceous chondrites. Earth Planet Sci Lett 401:327-336. https://doi.org/1 0.1016/j.epsl.2014.05.035

Bonal L, Quirico E, Bourot-Denise M, Montagnac G (2006) Determination of the petrologic type of CV3 chondrites by Raman spectroscopy of included organic matter. Geochim Cosmochim Acta 70(7):1849-1863. https://doi.org/1 0.1016/j.gca.2005.12.004

Bouvier A, Wadhwa M (2010) The age of the Solar System redefined by the oldest $\mathrm{Pb}-\mathrm{Pb}$ age of a meteoritic inclusion. Nat Geosci 3(9):637-641. https:// doi.org/10.1038/ngeo941

Brearley AJ, Fagan TJ, Washio M, MacPherson GJ (2014) FIB-TEM characterization of dmisteinbergite with intergrown biopyriboles in Allende Ca-Al-rich inclusions: Evidence for alteration in the presence of aqueous fluid. Lunar Planet Sci 45:2287

Brearley AJ, Krot AN (2013) Metasomatism in the early solar system: The record from chondritic meteorites. In: Metasomatism and the Chemical Transformation of Rock - Lecture Notes in Earth System Sciences, pp 659789. https://doi.org/10.1007/978-3-642-28394-9_15

Bullock EM, MacPherson GJ, Nagashima K, Krot AN, Petaev MI, Jacobsen SB, Ulyanov AA (2012) Forsterite-bearing Type B refractory inclusions from CV3 chondrites: From aggregates to volatilized melt droplets. Meteorit Planet Sci 47(12):2128-2147. https://doi.org/10.1111/j.1945-5100.2012.01396.x

Che S, Brearley AJ (2021) The formation and alteration history of a forsteritebearing Type C CAl from Allende: Evidence for a Type B CAI precursor, and implications for fluid-assisted metasomatism on the CV chondrite parent body. Geochim. Cosmochim. Acta 293:277-307.

Choi B-G, McKeegan KD, Leshin LA, Wasson JT (1997) Origin of magnetite in oxidized CV chondrites: in situ measurement of oxygen isotope compositions of Allende magnetite and olivine. Earth Planet Sci Lett 146(1-2): 337-349. https://doi.org/10.1016/S0012-821X(96)00229-4

Clayton RN, Onuma N, Grossman L, Mayeda TK (1977) Distribution of the presolar component in Allende and other carbonaceous chondrites. Earth Planet Sci Lett 34(2):209-224. https://doi.org/10.1016/0012-821X(77)90005-X

Connelly JN, Bizzarro M, Krot AN, Nordlund $\AA$, Wielandt D, Ivanova MA (2012) The absolute chronology and thermal processing of solids in the solar protoplanetary disk. Science 338(6107):651-655. https://doi.org/10.1126/ science.1226919

Cosarinsky M, Leshin LA, MacPherson GJ, Guan Y, Krot AN (2008) Chemical and oxygen isotopic compositions of accretionary rim and matrix olivine in $\mathrm{CV}$ chondrites: Constraints on the evolution of nebular dust. Geochim Cosmochim Acta 72(7):1887-1913. https://doi.org/10.1016/j.gca.2007.12.025

Davis AM, Richter FM, Mendybaev RA, Janney PE, Wadhwa M, McKeegan KD (2015) Isotopic mass fractionation laws for magnesium and their effects on ${ }^{26} \mathrm{Al}-{ }^{26} \mathrm{Mg}$ systematics in solar system materials. Geochim Cosmochim Acta 158:245-261. https://doi.org/10.1016/j.gca.2015.01.034

Davis AM, Simon SB, Grossman L (1994) Alteration of Allende type B1 CAls: When, where, and how. Lunar Planet Sci 25:315-316

De Laeter JR, Böhlke JK, De Bièvre P, Hidaka H, Peiser HS, Rosman KJR, Taylor PDP (2003) Atomic weights of the elements: Review 2000 (IUPAC Technical Report). Pure Appl Chem 75(6):683-800. https://doi.org/10.1351/pac2003 75060683

Doyle PM, Jogo K, Nagashima K, Krot AN, Wakita S, Ciesla FJ, Hutcheon ID (2015) Early aqueous activity on the carbonaceous and ordinary chondrite parent asteroids recorded by secondary fayalite. Nature Comm $6: 1-10$
Fagan TJ, Aragane H, Enokido Y, Brearley AJ (2015) Meteorit Planet Sci 50, Special Issue:78 $8^{\text {th }}$ Annual Meeting of the Meteoritical Society 2015 July 27-31 Berkeley: 5094

Fagan TJ, Guan Y, MacPherson GJ, Huss GR (2005) Al-Mg isotopic evidence for separate nebular and parent-body alteration events in two Allende CAls. Lunar Planet. Sci 36:1820

Fagan TJ, Guan Y, MacPherson GJ (2006) Al-Mg isotopic evidence for separate nebular and parent-body alteration events in two Allende CAls. Lunar Planet. Sci 37:1213

Fagan TJ, Guan Y, MacPherson GJ (2007) Al-Mg isotopic evidence for episodic alteration of Ca-Al-rich inclusions from Allende. Meteorit Planet Sci 42(7-8): 1221-1240. https://doi.org/10.1111/j.1945-5100.2007.tb00570.x

Fintor K, Park C, Nagy S, Pal-Molnar E, Krot AN (2014) Hydrothermal origin of hexagonal $\mathrm{CaAl}_{2} \mathrm{Si}_{2} \mathrm{O}_{8}$ (dmisteinbergite) in a compact Type A CAl from the North West Africa 2086 CV3 chondrite. Meteorit Planet Sci 49(5):812-823. https://doi.org/10.1111/maps.12294

Ford RL, Brearley AJ (2008) Element exchange between matrix and CAls in the Allende meteorite. Lunar Planet Sci 39:2399

Ganino C, Libourel G (2017) Reduced and unstratified crust in CV chondrites parent body. Nature Comm 8:1-10

Grimm RE, McSween HY Jr (1989) Water and the thermal evolution of carbonaceous chondrite parent bodies. Icarus 82(2):244-280. https://doi.org/1 0.1016/0019-1035(89)90038-9

Grossman L (1975) Petrography and mineral chemistry of Ca-rich inclusions in the Allende meteorite. Geochim Cosmochim Acta 39(4):433-434. https://doi. org/10.1016/0016-7037(75)90099-X

Grossman L (1980) Refractory inclusions in the Allende meteorite. Annu Rev Earth Planet Sci 8(1):559-608. https://doi.org/10.1146/annurev.ea.08.050180.003015

Harvey AH, Bellows JC (1997) Evaluation and correlation of steam solubility data for salts and minerals of interest in the power industry. National Institute for Standards and Technology, Gaithersburg Technical Note No.1387

Hashimoto A, Grossman L (1987) Alteration of Al-rich inclusions inside amoeboid olivine aggregates in the Allende meteorite. Geochim Cosmochim Acta 51(6):1685-1704. https://doi.org/10.1016/0016-7037(87)90348-6

Hiyagon H (1998) Distribution of oxygen isotopes in and around some refractory inclusions from Allende. Lunar Planet Sci 29:1582

Hutcheon ID, Newton RC (1981) Mg isotopes, mineralogy, and mode of formation of secondary phases in C3 refractory inclusions. Lunar Planet Sci 12:491-493

Hutcheon ID, Steele IM, Smith JV, Clayton RN (1978) Ion microprobe, electron microprobe and cathodoluminescence data for Allende inclusions with emphasis on plagioclase chemistry. Proc Lunar Planet Sci Conf 9:1345-1368

Itoh S, Yurimoto H (2003) Contemporaneous formation of chondrules and refractory inclusions in the early solar system. Nature 423(6941):728-731. https://doi.org/10.1038/nature01699

Jacobsen B, Matzel J, Hutcheon ID, Krot AN, Nagashima K, Ishii HA, Ramon E, Meyer BS, Davis AM, Ciesla FJ, Yin Q-Z (2011) Formation of short-lived radionuclides during epoch of late-stage irradiation in the protoplanetary disk. Astrophys J 731(2):L28-L31. https://doi.org/10.1088/2041-8205/731/2/L28

Kawasaki N, Simon SB, Grossman L, Sakamoto N, Yurimoto H (2018) Crystal growth and disequilibrium distribution of oxygen isotopes in an igneous CaAl-rich inclusion from the Allende carbonaceous chondrite. Geochim Cosmochim Acta 221:318-341. https://doi.org/10.1016/j.gca.2017.05.035

Keller LP, Buseck PR (1991) Calcic micas in the Allende meteorite: Evidence for hydration reactions in the early solar nebula. Science 252(5008):946-949. https://doi.org/10.1126/science.252.5008.946

Kimura M, Ikeda Y (1995) Anhydrous alteration of Allende chondrules in the solar nebula; II, Alkali-Ca exchange reactions and formation of nepheline, sodalite and Ca-rich phases in chondrules. Proc NIPR Symp Antarctic Meteorites 8:123-138

Kita NT, Yin Q-Z, MacPherson GJ, Ushikubo T, Jacobsen B, Nagashima K, Kurahashi E, Krot AN, Jacobsen SB (2013) ${ }^{26} \mathrm{Al}-{ }^{26} \mathrm{Mg}$ isotope systematics of the first solids in the early solar system. Meteorit Planet Sci 48(8):1383-1400. https://doi.org/10.1111/maps.12141

Kojima T, Tomeoka K (1996) Indicators of aqueous alteration and thermal metamorphism on the CV parent body: Microtextures of a dark inclusion from Allende. Geochim Cosmochim Acta 60(14):2651-2666. https://doi.org/1 0.1016/0016-7037(96)00116-0

Komada N, Westrum EF Jr, Hemingway BS, Zolotov MY, Semenov Yu V, Khodakovsky IL, Anovitz LM (1995) Thermodynamic properties of sodalite at temperatures from $04 \mathrm{~K}$ to $0999 \mathrm{~K}$. J Chem Thermod 27(10):1119-1132. https://doi.org/10.1006/jcht.1995.0116 
Kööp L, Nakashima D, Heck PR, Kita NT, Tenner TJ, Krot AN, Nagashima K, Park C, Davis AM (2016) New constraints for the relationship between ${ }^{26} \mathrm{Al}$ and oxygen, calcium, and titanium isotopic variation in the early Solar System from a multi-element isotopic study of Spinel-Hibonite Inclusions. Geochim Cosmochim Acta 184:151-172. https://doi.org/10.1016/j.gca.2016.04.018

Krot AN (2019) Refractory inclusions in carbonaceous chondrites: Records of early solar system processes (Invited Review). Meteorit Planet Sci 54(8):1647-1692. https://doi.org/10.1111/maps.13350

Krot AN, Alexander CM, Nagashima K, Ciesla FJ, Fujiya W, Bonal L (2015) Aqueous activity and sources of water on the chondrite parent asteroids. Asteroids IV: 635-661

Krot AN, Chaussidon M, Yurimoto H, Sakamoto N, Nagashima K, Hutcheon ID, MacPherson GJ (2008) Oxygen isotopic compositions of Allende Type C CAls: Evidence for isotopic exchange during nebular melting and asteroidal metamorphism. Geochim Cosmochim Acta 72(10):2534-2555. https://doi. org/10.1016/j.gca.2008.02.011

Krot AN, Hiyagon H, Petaev Ml, Meibom A (2000) Oxygen isotopic compositions of secondary Ca-Fe-rich silicates from the Allende dark inclusions: Evidence against high-temperature formation. Lunar Planet Sci 31:1463

Krot AN, Ma C, Nagashima K, Davis AM, Beckett JR, Simon SB, Komatsu M, Fagan TJ, Brenker F, Ivanova MA, Bischoff A (2019b) Mineralogy, petrography, and oxygen isotopic compositions of ultrarefractory inclusions from carbonaceous chondrites. Geochemistry 79(4):125519. https://doi.org/10.101 6/j.chemer.2019.07.001

Krot AN, Nagashima K, Fintor K, Pál-Molnár E (2018) Evidence for oxygen isotopic exchange in chondrules from Kaba (CV3.1) carbonaceous chondrite during aqueous fluid - rock interaction on the CV parent asteroid. Acta Geograph Geol Meteorol Debrecina 13:137-149

Krot AN, Nagashima K, Fintor K, Pál-Molnár E (2019a) Evidence for oxygen-isotope exchange in refractory inclusions from Kaba (CV3.1) carbonaceous chondrite during fluid-rock interaction on the CV parent asteroid. Geochim Cosmochim Acta 246:419-435

Krot AN, Nagashima K, Hutcheon ID, Ishii HA, Yin Q-Z, Davis AM, Simon SB (2010) Mineralogy, petrography, oxygen and magnesium isotopic compositions and formation age of grossular-bearing assemblages in the Allende CAls. Lunar Planet Sci 41:1406

Krot AN, Nagashima K, Lyons JR, Lee J-E, Bizzarro M (2020b) Oxygen isotopic heterogeneity in the early solar system inherited from the protosolar molecular cloud. Sci Adv 6:eaay2724

Krot AN, Nagashima K, Petaev MI, Libourel G (2020a) Metasomatic alteration of the Allende CAls: Mineralogy, petrography, and oxygen isotopic compositions. Lunar Planet Sci 51:1831

Krot AN, Nagashima K, Simon SB, Ma C, Connolly HC Jr, Huss GR, Davis AM, Bizzarro M (2019c) Mineralogy, petrography, and oxygen and aluminummagnesium isotope systematics of grossite-bearing refractory inclusions. Geochemistry 79(4):125529. https://doi.org/10.1016/j.chemer.2019.08.001

Krot AN, Nagashima K, Wasserburg GJ, Huss GR, Papanastassiou D, Davis AM, Hutcheon ID, Bizzarro M (2014) Calcium-aluminum-rich inclusions with fractionation and unknown nuclear effects (FUN CAls): I. Mineralogy, petrology, and oxygen-isotope compositions. Geochim Cosmochim Acta 145:206-247

Krot AN, Petaev MI, Meibom A, Keil K (2001b) In situ growth of Ca-rich rims around Allende dark inclusions. Geochem Int 36:351-368

Krot AN, Petaev MI, Scott ERD, Choi B-G, Zolensky ME, Keil K (1998b) Progressive alteration in CV3 chondrites: More evidence for asteroidal alteration. Meteorit Planet Sci 33(5):1065-1085. https://doi.org/10.1111/j.1945-5100.1998.tb01713.x

Krot AN, Scott ERD, Zolensky ME (1995) Mineralogic and chemical variations among CV3 chondrites and their components: Nebular and asteroidal processing. Meteoritics 30(6):748-775. https://doi.org/10.1111/j.1945-5100.1 995.tb01173.x

Krot AN, Ulyanov AA, Meibom A, Keil K (2001a) Forsterite-rich accretionary rims around $\mathrm{Ca}$, Al-rich inclusions from the reduced CV3 chondrite Efremovka. Meteorit Planet Sci 36(5):611-628. https://doi.org/10.1111/j.1945-5100.2001. tb01904.x

Krot AN, Yurimoto H, Hutcheon ID, Libourel G, Chaussidon M, Petaev MI, MacPherson GJ, Paque-Heather J, Wark D (2007b) Anorthite-rich, igneous (Type C) Ca,Al-rich inclusions from the CV carbonaceous chondrite Allende: Evidence for multistage formation history. Geochim Cosmochim Acta 71:4342-4364

Krot AN, Yurimoto H, Hutcheon ID, MacPherson GJ, Paque J (2007a) Remelting of refractory inclusions in the chondrule-forming regions: Evidence from the chondrule-bearing Type C calcium-aluminum-rich inclusions. Meteorit Planet Sci 42:1197-1221

Krot AN, Zolensky ME, Keil K, Scott ERD, Nakamura K (1998a) Secondary Ca-Ferich minerals in the Bali-like and Allende-like oxidized CV3 chondrites and Allende dark inclusions. Meteorit Planet Sci 33(4):623-645. https://doi.org/1 0.1111/j.1945-5100.1998.tb01668.x

Larsen K, Trinquier A, Paton C, Schiller M, Wielandt D, Ivanova M, Connelly J, Nordlund A, Krot AN, Bizzarro M (2011) Evidence for magnesium-isotope heterogeneity in the solar protoplanetary disk. Astrophys J 735(2):L37-L40. https://doi.org/10.1088/2041-8205/735/2/L37

Lodders K (2021) Relative atomic solar system abundances, mass fractions, and atomic masses of the elements and their isotopes, composition of the solar photosphere, and compositions of the major chondritic meteorite groups. Space Sci Rev 217(3):44. https://doi.org/10.1007/s11214-021-00825-8

MacPherson G. J. (2014) Calcium-aluminum-rich inclusions in chondritic meteorites. In Meteorites and Cosmochemical Processes (ed. A. M. Davis). Treatise of Geochemistry, 2nd (Exec. Eds. H. D. Holand and K. K. Turekian), Elsevier, Oxford 1:139-179.

MacPherson GJ, Grossman L (1984) "Fluffy" Type A Ca-, Al-rich inclusions in the Allende meteorite. Geochim Cosmochim Acta 48(1):29-46. https://doi.org/1 0.1016/0016-7037(84)90347-8

MacPherson GJ, Nagashima K, Krot AN, Doyle PM, Ivanova MA (2017) ${ }^{53} \mathrm{Mn}-{ }^{53} \mathrm{Cr}$ chronology of Ca-Fe silicates in CV3 chondrites. Geochim Cosmochim Acta 201:260-274. https://doi.org/10.1016/j.gca.2016.09.032

MacPherson GJ, Paque JM, Stolper E, Grossman L (1984) The origin and significance of reverse zoning in melilite from Allende Type B inclusions. J Geol 92(3):289-305. https://doi.org/10.1086/628861

Makide K, Nagashima K, Krot AN, Huss GR, Hutcheon ID, Bischoff A (2009) Oxygen- and magnesium-isotope compositions of calcium-aluminum-rich inclusions from CR2 carbonaceous chondrites. Geochim Cosmochim Acta 73(17):5018-5051. https://doi.org/10.1016/j.gca.2009.01.042

McGuire AV, Hashimoto A (1989) Origin of zoned fine-grained inclusions in the Allende meteorite. Geochim Cosmochim Acta 53(5):1123-1133. https://doi. org/10.1016/0016-7037(89)90218-4

McKeegan KD, Kallio APA, Heber VS, Jarzebinski G, Mao PH, Coath CD, Kunihiro T, Wiens RC, Nordholt JE, Moses RW Jr, Reisenfeld DB, Jurewicz AJG, Burnett DS (2011) The oxygen isotopic composition of the Sun inferred from captured solar wind. Science 332(6037):1528-1532. https://doi.org/10.1126/science.1204636

Mendybaev RA, Williams CD, Spicuzza MJ, Richter FM, Valley JW, Fedkin AV, Wadhwa M (2017) Thermal and chemical evolution in the early Solar System as recorded by FUN CAls: Part II - Laboratory evaporation of potential CMS-1 precursor material. Geochim Cosmochim Acta 201:49-64. https://doi.org/10.1 016/j.gca.2016.08.034

Nagashima K, Krot AN, Huss GR (2015) Oxygen-isotope compositions of chondrule silicates and matrix grains in Kakangari K-grouplet chondrite. Geochim Cosmochim Acta 151:49-67. https://doi.org/10.1016/j.gca.2014.12.012

Nagashima K, Thomen A, Krot AN, Huss GR, Kim NK, Park C (2020) Investigation of instrumental fractionation in SIMS analyses of magnesium, silicon, and oxygen isotopes in silicates and oxides. Lunar Planet Sci 51:1719

Oelkers EH, Helgeson HC, Shock EL, Sverjensky DA, Johnson JW, Pokrovskii VA (1995) Summary of the apparent standard partial molal Gibbs free energies of formation of aqueous species, minerals, and gases at pressures 1 to 5000 bars and temperatures 25 to $1000{ }^{\circ} \mathrm{C}$. J Phys Chem Ref Data 24(4):1401-1560. https://doi.org/10.1063/1.555976

Park C, Nagashima K, Ma C, Krot AN, Bizzarro M (2013) Two generations of hexagonal $\mathrm{CaAl}_{2} \mathrm{Si}_{2} \mathrm{O}_{8}$ (dmisteinbergite) in a Type B2 FUN CAI STP-1. Meteorit Planet Sci 48(Supp):048

Petaev MI, Moronenko MV (1997) Thermodynamic modeling of aqueous alteration in CV chondrites. In: Zolensky ME, Krot AN, Scott ERD (eds) Workshop on ParentBody and Nebular Modification of Chondritic Materials. LPI Tech. Rept. No. 9702, Part 1, Lunar and Planetary Institute, Houston, pp 49-50

Plyasunov AV (2011) Thermodynamic properties of $\mathrm{H}_{4} \mathrm{SiO}_{4}$ in the ideal gas state as evaluated from experimental data. Geochim Cosmochim Acta 75(13): 3853-3865. https://doi.org/10.1016/j.gca.2011.04.016

Pouchou JL, Pichoir F (1984) A new model for quantitative x-ray microanalysis. Part I: Application to the analysis of homogeneous samples. Rech Aerosp 3: 13-38

Robie RA, Hemingway BS (1995) Thermodynamic Properties of Minerals and Related Substances at $298.15 \mathrm{~K}$ and 1 Bar ( $10^{5}$ Pascals) Pressures and at HigherTemperatures. US Geological Survey Bulletin, 2131, p. 461 
Simon Jl, Hutcheon ID, Simon SB, Matzel JEP, Ramon EC, Weber PK, Grossman L, DePaolo DJ (2011) Oxygen isotope variations at the margin of a CAl records circulation within the solar nebula. Science 331(6021):1175-1178. https://doi. org/10.1126/science. 1197970

Simon Jl, Matzel JEP, Simon SB, Hutcheon ID, Ross DK, Weber PK, Grossman L (2016) Oxygen isotopic variations in the outer margins and Wark-Lovering rims of refractory inclusions. Geochim Cosmochim Acta 186:242-276. https:// doi.org/10.1016/j.gca.2016.04.025

Simon Jl, Ross DK, Nguyen AN, Simon SB, Messenger S (2019) Molecular cloud origin for oxygen isotopic heterogeneity recorded by a primordial spinel-rich refractory inclusion. Astrophys J Lett 884(2):L29. https://doi.org/10.3847/20418213/ab43e4

Simon SB, Davis AM, Grossman L (1998) Formation of an unusual compact Type A refractory inclusion from Allende. Meteorit Planet Sci 33(1):115-126. https://doi.org/10.1111/j.1945-5100.1998.tb01613.x

Simon SB, Davis AM, Grossman L (1999) Origin of compact type A refractory inclusions from CV3 carbonaceous chondrites. Geochim Cosmochim Acta 63(7-8):1233-1248. https://doi.org/10.1016/S0016-7037(99)00046-0

Simon SB, Davis AM, Grossman L (2001) Formation of orange hibonite, as inferred from some Allende inclusions. Meteorit Planet Sci 36(3):331-350. https://doi.org/10.1111/j.1945-5100.2001.tb01877.x

Simon SB, Grossman L (2006) A comparative study of melilite and fassaite in Types B1 and B2 refractory inclusions. Geochim Cosmochim Acta 70(3):780798. https://doi.org/10.1016/j.gca.2005.09.018

Simon SB, Sutton SR, Grossman L (2007) Valence of titanium and vanadium in pyroxene in refractory inclusion interiors and rims. Geochim Cosmochim Acta 71(12):3098-3118. https://doi.org/10.1016/j.gca.2007.03.027

Svoboda R (2006) Chemistry in steam turbines. PowerPlant Chemistry 8:270-276

Tomeoka K, Buseck PR (1982) Intergrown mica and montmorillonite in the Allende carbonaceous chondrite. Nature 299(5881):326-327. https://doi.org/1 $0.1038 / 299326 \mathrm{aO}$

Ushikubo T, Guan Y, Hiyagon H, Sugiura N, Leshin LA (2007) ${ }^{36} \mathrm{Cl},{ }^{26} \mathrm{Al}$, and O isotopes in an Allende type B2 CAl: Implications for multiple secondary alteration events in the early solar system. Meteorit Planet Sci 42(7-8):12671279. https://doi.org/10.1111/j.1945-5100.2007.tb00573.x

Ushikubo T, Kimura M, Kita NT, Valley JW (2012) Primordial oxygen isotope reservoirs of the solar nebula recorded in chondrules in Acfer 094 carbonaceous chondrite. Geochim Cosmochim Acta 90:242-264. https://doi. org/10.1016/j.gca.2012.05.010

Ushikubo T, Tenner TJ, Hiyagon H, Kita NT (2017) A long duration of the ${ }^{16} \mathrm{O}$-rich reservoir in the solar nebula, as recorded in fine-grained refractory inclusions from the least metamorphosed carbonaceous chondrites. Geochem Cosmochim Acta 201:103-122. https://doi.org/10.1016/j.gca.2016.08.032

Wakaki S, Itoh S, Tanaka T, Yurimoto H (2013) Petrology, trace element abundances and oxygen isotopic compositions of a compound CAlchondrule object from Allende. Geochim Cosmochim Acta 102:261-279. https://doi.org/10.1016/j.gca.2012.10.039

Wark DA (1981) Alteration and metasomatism of Allende Ca-Al-rich materials. Lunar Planet Sci 12:1145-1147

Wark DA (1987) Plagioclase-rich inclusions in carbonaceous chondrite meteorites: Liquid condensates? Geochim Cosmochim Acta 51(2):221-242. https://doi. org/10.1016/0016-7037(87)90234-1

Wark DA, Boynton WV, Keays RR, Palme H (1987) Trace element and petrologic clues to the formation of forsterite-bearing Ca-Al-rich inclusions in the Allende meteorite. Geochim Cosmochim Acta 51(3):607-622. https://doi. org/10.1016/0016-7037(87)90073-1

Wark DA, Lovering JF (1982b) The nature and origin of type B1 and B2 Ca-Al-rich inclusions in the Allende meteorite. Geochim Cosmochim Acta 46(12):25812594. https://doi.org/10.1016/0016-7037(82)90379-9

Wilkin RT, Barnes HL (1998) Solubility and stability of zeolites in aqueous solution: I. Analcime, Na-, and K-clinoptilolite. Am Mineral 83(7-8):746-761. https://doi. org/10.2138/am-1998-7-807

Williams CR, Ushikubo T, Bullock ES, Janney ES, Hines RR, Kita NT, Hervig RL, MacPherson GJ, Mendybaev RA, Richter FM, Wadhwa M (2017) Thermal and chemical evolution in the early solar system as recorded by FUN CAls: Part I - Petrology, mineral chemistry, and isotopic composition of Allende FUN CAI CMS-1. Geochim Cosmochim Acta 201:25-48. https://doi.org/10.1016/j.gca.2 016.10 .053

Yurimoto $H$, Ito M, Nagasawa H (1998) Oxygen isotope exchange between refractory inclusion in Allende and solar nebula gas. Science 282(5395):18741877. https://doi.org/10.1126/science.282.5395.1874
Yurimoto H, Krot AN, Choi B-G, Aléon J, Kunihiro T, Brearley AJ (2008) Oxygen isotopes of chondritic components. In Oxygen in the Solar System (ed. MacPherson G. J.). Rev Mineral Geochem 68(1):141-187. https://doi.org/1 0.2138/rmg.2008.68.8

Zheng Y-F (1991) Calculation of oxygen isotope fractionation in metal oxides. Geochim Cosmochim Acta 55:2299-2307

Zheng Y-F (1993) Calculation of oxygen isotope fractionation in anhydrous silicate minerals. Geochem Cosmochim Acta 57:1079-1091

Zolotov MY, Mironenko MV (2007) Hydrogen chloride as a source of acid fluids in parent bodies of chondrites. Lunar Planet Sci 38:2340

\section{Publisher's Note}

Springer Nature remains neutral with regard to jurisdictional claims in published maps and institutional affiliations.

\section{Submit your manuscript to a SpringerOpen ${ }^{\circ}$ journal and benefit from:}

- Convenient online submission

- Rigorous peer review

- Open access: articles freely available online

- High visibility within the field

- Retaining the copyright to your article

Submit your next manuscript at $\boldsymbol{\nabla}$ springeropen.com 